\title{
Review \\ The Polygenic Nature and Complex Genetic Architecture of Specific Learning Disorder
}

\author{
Marianthi Georgitsi ${ }^{1, *(\mathbb{C}}$, Iasonas Dermitzakis ${ }^{1}{ }^{(\mathbb{D}}$, Evgenia Soumelidou ${ }^{1}$ and Eleni Bonti ${ }^{2,3}$ (]) \\ 1 1st Laboratory of Medical Biology-Genetics, School of Medicine, Aristotle University of Thessaloniki, \\ 54124 Thessaloniki, Greece; iasonasd@auth.gr (I.D.); esoumelid@auth.gr (E.S.) \\ 2 1st Psychiatric Clinic, School of Medicine, Aristotle University of Thessaloniki, \\ "Papageorgiou" General Hospital, 54603 Thessaloniki, Greece; bonti@auth.gr \\ 3 Department of Education, School of Education, University of Nicosia, 2417 Nicosia, Cyprus \\ * Correspondence: margeorgitsi@auth.gr
}

check for updates

Citation: Georgitsi, M.; Dermitzakis,

I.; Soumelidou, E.; Bonti, E. The Polygenic Nature and Complex Genetic Architecture of Specific Learning Disorder. Brain Sci. 2021, 11, 631. https://doi.org/10.3390/

brainsci11050631

Academic Editor: Paola Venuti

Received: 8 April 2021

Accepted: 12 May 2021

Published: 14 May 2021

Publisher's Note: MDPI stays neutral with regard to jurisdictional claims in published maps and institutional affiliations.

Copyright: (c) 2021 by the authors. Licensee MDPI, Basel, Switzerland. This article is an open access article distributed under the terms and conditions of the Creative Commons Attribution (CC BY) license (https:// creativecommons.org/licenses/by/ $4.0 /)$.

\begin{abstract}
Specific Learning Disorder (SLD) is a multifactorial, neurodevelopmental disorder which may involve persistent difficulties in reading (dyslexia), written expression and/or mathematics. Dyslexia is characterized by difficulties with speed and accuracy of word reading, deficient decoding abilities, and poor spelling. Several studies from different, but complementary, scientific disciplines have investigated possible causal/risk factors for SLD. Biological, neurological, hereditary, cognitive, linguistic-phonological, developmental and environmental factors have been incriminated. Despite worldwide agreement that SLD is highly heritable, its exact biological basis remains elusive. We herein present: (a) an update of studies that have shaped our current knowledge on the disorder's genetic architecture; (b) a discussion on whether this genetic architecture is 'unique' to SLD or, alternatively, whether there is an underlying common genetic background with other neurodevelopmental disorders; and, (c) a brief discussion on whether we are at a position of generating meaningful correlations between genetic findings and anatomical data from neuroimaging studies or specific molecular/cellular pathways. We conclude with open research questions that could drive future research directions.
\end{abstract}

Keywords: specific learning disorder (SLD); dyslexia; dyscalculia; genetic variants; susceptibility

\section{Introduction}

Specific Learning Disorder (SLD) is a complex disorder with varying manifestations and considerable differences in interpersonal characteristics, albeit present worldwide. According to DSM-5 and the National Joint Committee on Learning Disabilities (NJCLD), SLD is a general term that refers to a group of disorders [1-3], which may involve difficulties in reading (dyslexia), written expression (dysgraphia) and/or mathematics (dyscalculia), albeit not accounted for by low intelligence (IQ), sensory acuity (visual problems), poor learning opportunities, or developmental delay (e.g., intellectual disability). Learning disabilities may co-occur with the aforementioned impairments, but are not the result of these conditions [1,4].

The prevalence of SLD varies between 3-12\% among the general population, depending on factors such as stringency of measurement cut-offs used for identification [5-7], country and level of phonological transparency of the spoken language, sex (male:female ratio 2-3.7:1) [8-10], age of assessment, different theoretical perspectives as regards causality, and assessment tools criteria used [6,11]. DSM-5 describes SLD as a neurodevelopmental disorder with a biological origin, which includes an interaction of genetic, epigenetic, and environmental factors. SLD is readily apparent in the early school years in most individuals; symptoms are usually detected when students show a learning profile which is qualitatively lower than their chronological and mental age. However, in some cases, difficulties may become obvious at a later age, when the academic demands rise and exceed 
the individual's limited capacities, for example during adolescence or adulthood [2,12]. SLD is a lifelong disorder; its impact can have undesirable outcomes for children, as well as for older individuals, on educational, social, financial and occupational level.

Several studies originating from different scientific fields have tried to investigate the possible causal and/or risk factors of SLD. Neurological-neuroanatomical, biological (genetic, epigenetic), cognitive-information processing, linguistic-phonological, developmental and environmental factors have been incriminated. However, until presently, scientific communities worldwide have not come to an agreement as regards to the exact causes and nature of SLD, neither have they agreed to a commonly accepted definition [13-15]. Issues of comorbidity make differential diagnosis an even more complicated task [16]. Arithmetic, reading, or spelling deficits are common in cases with already existing problems in one academic domain compared to the general population [17]; increased dyscalculia rates are observed in families of children with dyslexia [18]. Additionally, dysgraphia rarely occurs alone and frequently co-occurs with dyslexia [19]. Moreover, it is not uncommon for individuals with SLD to show symptoms of Attention-Deficit/Hyperactivity Disorder (ADHD), Specific Language Impairment (SLI), motor-coordination deficiencies, emotionalbehavioral difficulties, anxiety, depression, personality disorders, or other conditions; it is not clear whether these conditions comorbid with SLD as simultaneous disorders or are secondary problems deriving from the ongoing academic failure. Nevertheless, each year, a considerable number of children and adolescents as well as adults are referred to diagnostic centers seeking help with their learning difficulties [12,20,21].

From the genetics perspective, SLD is a complex disorder with a strong genetic component; heritability estimates from family and twin studies vary between $40-70 \%\left(h^{2}=0.52\right.$ for dyslexia and 0.61 for dyscalculia) [22-24]. Moreover, reading-related abilities such as word recognition, phoneme awareness, orthographic choice, and phoneme decoding have shown significant heritability estimates above 50\% [25]. These high heritability estimates were calculated based on twin studies; a proportion of this genetic component can be attributed to common variants of the human genome, such as single nucleotide polymorphisms (SNPs). According to the latest genome-wide association study (GWAS) on dyslexia, SNP-based heritability yielded an estimate of $20 \%$ or $25 \%$, assuming a dyslexia prevalence of $5 \%$ or $10 \%$, respectively [26]. The remaining of the genetic risk or "missing heritability" of dyslexia could be potentially explained by other types of genomic variants, such as copy number variants (CNVs) and rare variants. The identification of the latter type of variants requires different methodological and analytical approaches, such as massive parallel deep sequencing, also known as next-generation sequencing (NGS).

Herein, we have synthesized a comprehensive review summarizing our current knowledge on the genetic basis of SLD by compiling data from a significant number of studies. By reviewing the literature from the past 20 years, more or less in chronological order when taking into account the methodological advancements, we inevitably recapitulate the view that underlies most complex neurodevelopmental disorders; the genetic architecture of Specific Learning Disorder is not specific. We have tried to address this prevailing concept in several aspects: (a) we present the current knowledge on the genetic architecture of SLD and the predisposing factors that are known to underlie specific SLD domains (dyslexia versus dyscalculia) (Sections 2 and 3); (b) we discuss whether this genetic architecture is unique to SLD or, alternatively, whether there is an underlying common genetic background between SLD and other neurodevelopmental disorders (such as ADHD) (Section 4); (c) we briefly discuss whether we can relate genetic findings with anatomical data from neuroimaging studies or with specific molecular and cellular pathways (Sections 5 and 6); (d) we conclude with open research questions that could drive future research directions (Section 7).

\section{Exploring Genetic Susceptibility to SLD-The Early Times}

SLD appears to aggregate in families; the relative risk of SLD in reading or mathematics is substantially higher (4-8 times and $5-10$ times higher, respectively) in first-degree 
relatives of individuals with these learning difficulties $[1,27,28]$. Family history of reading difficulties and parental literacy skills, as well as mathematical difficulties, predict literacy problems or SLD in offspring, indicating the combined role of genetic and environmental factors $[1,29,30]$. Back when the first efforts to determine the genetic basis of dyslexia started to appear in the literature (Table 1), the disorder was assumed to follow an autosomal dominant inheritance pattern with high, but incomplete, penetrance [31,32]. In the next two decades, it became clear that SLD, and specifically dyslexia, is a complex disorder with marked genetic heterogeneity, as manifested by the identification of at least nine genetic loci spread throughout the genome (Table 1).

Clues into the genetic underpinnings of reading-related traits originally emerged from classical, hypothesis-free, genome-wide linkage screens, linkage analysis in wellphenotyped pedigrees with multiple affected cases, or the detection of rare chromosomal aberrations (mostly translocations) in dyslexic individuals, likely disrupting a susceptibility locus. Owing to the prior view of dyslexia as an autosomal dominant disorder, Online Mendelian Inheritance in Man curates these earlier reports [33]. Briefly, more than nine loci have been identified as candidates for susceptibility to SLD, with several genes, particularly DYX1C1, ROBO1, KIAA0319, and DCDC2, repeatedly linked to the disorder and/or measures of reading processes disturbed in dyslexia. Overall, many excellent reviews have covered the earlier efforts to unravel the genetic component of dyslexia [34-37]. Thus, instead of presenting a redundant text herein, we have compiled the seminal studies that led to the identification of dyslexia-associated genes and loci in Table 1. Apart from the categorical diagnosis, we have also recorded quantitative traits often used as proxies (or endophenotypes) to address the general dyslexia phenotype. This is a common approach successfully used to draw closer to the underlying genetic deficit in complex phenotypes [38]. However, the correlation between these endophenotypes and genetic susceptibility markers is far from optimal, since either the same locus has been associated with different SLD-related traits in different studies [39], or the same quantitative trait has shown marked genetic heterogeneity (Table 1 ).

Following up on gene mapping, a significant number of studies explored associations between specific variants in candidate susceptibility genes and SLD domains or related traits; we summarize the data in Table 2. Then, for the rest of the review, we focus on the latest advances in the field, considering the shift in the analytical approaches used, driven by the advent of high-throughput genotyping technologies and NGS. We discuss the most recent studies in the text and provide a compilation in Table 3.

Less is known about the genetics of mathematical abilities or written expression skills, with few genetic studies conducted thus far (Tables 1-3). In nearly half of SLD cases, dyslexia and dyscalculia co-occur [40]. This co-occurrence is more frequent than expected by chance and could be partially attributed to shared genetic influences, according to the "generalist genes" hypothesis $[41,42]$. However, there are still very limited genetic data to support such shared genetic influences $[43,44]$.

Table 1. Earlier studies (1993-2013) presenting evidence for association of genomic loci with SLD and/or related traits.

\begin{tabular}{|c|c|c|c|}
\hline Phenotype Domain/Trait & Locus (Gene(s)) ${ }^{1}$ & Means of Identification & Reference \\
\hline \multicolumn{4}{|c|}{ Classical DYX loci } \\
\hline Dyslexia/SWR & 15q15-q21 (DYX1) & Locus-specific linkage analysis & [45] \\
\hline Severe dyslexia/PA & 15q21 (DYX1C1) & Chromosomal translocation & {$[46]$} \\
\hline Dyslexia/PA & 6p22-p21 (DYX2) & Locus-specific linkage analysis & [45] \\
\hline Dyslexia & 6p22 (KIAA0319, DCDC2) & Linkage analysis and association & [47] \\
\hline Dyslexia & 6p22 (KIAA0319) & Linkage analysis and association & [48] \\
\hline Reading disability & 6p22 (KIAA0319) & Linkage disequilibrium mapping & [49] \\
\hline Severe dyslexia & 6p22-p21 (DCDC2) & Linkage disequilibrium mapping & {$[50]$} \\
\hline
\end{tabular}


Table 1. Cont.

\begin{tabular}{|c|c|c|c|}
\hline Phenotype Domain/Trait & Locus (Gene(s)) $^{1}$ & Means of Identification & Reference \\
\hline \multicolumn{4}{|c|}{ Classical DYX loci } \\
\hline Dyslexia/RAN & 6p21 (separate from DYX2) & Genome-wide linkage scan & [51] \\
\hline Dyslexia & 2p16-p15 (DYX3) & Genome-wide linkage scan & {$[52]$} \\
\hline Dyslexia & $2 \mathrm{p}(\mathrm{DYX} 3)$ & Locus-specific linkage analysis & [25] \\
\hline $\begin{array}{c}\text { Dyslexia/word- and } \\
\text { non-word reading, RAN }\end{array}$ & $2 \mathrm{p}(\mathbf{D Y X} 3)$ & Locus-specific linkage analysis & [39] \\
\hline Dyslexia & 2p12 (MRPL19, C2orf3) & Linkage disequilibrium mapping & [53] \\
\hline Spelling & 6q11.2-q12 (DYX4) & Genome-wide linkage scan & [54] \\
\hline \multirow{2}{*}{$\begin{array}{l}\text { PA, naming speed, verbal } \\
\text { short-term memory }\end{array}$} & 3p12-q13 (DYX5) & Genome-wide linkage scan & [55] \\
\hline & 3 p12 (ROBO1) & Chromosomal translocation & [56] \\
\hline \multirow{3}{*}{$\begin{array}{l}\text { SWR, PA (reading-related } \\
\text { processes) } \\
\text { Dyslexia }\end{array}$} & 18p11.2 (DYX6) & $\begin{array}{c}\text { Genome-wide linkage scan } \\
\text { (QTL-based) }\end{array}$ & [57] \\
\hline & $18 \mathrm{p} 11.2-\mathrm{q} 12.2$ & $\begin{array}{l}\text { Locus-specific linkage analysis } \\
\text { and association }\end{array}$ & [58] \\
\hline & \multicolumn{2}{|l|}{$(M C 5 R, D Y M, N E D D 4 L)$} & \\
\hline Dyslexia & 11p15.5 (DYX7) & Linkage analysis and association & [59] \\
\hline $\begin{array}{c}\text { Severe dyslexia/speech } \\
\text { development }\end{array}$ & $1 \mathrm{p} 22$ & Chromosomal translocation & {$[60]$} \\
\hline Dyslexia & 1p36-p34 (DYX8) & Chromosomal translocation & [61] \\
\hline Dyslexia/RAN & 1p (DYX8) & Locus-specific linkage analysis & {$[62]$} \\
\hline Dyslexia/spelling & 1p36-p34 (DYX8) & $\begin{array}{l}\text { Genome-wide linkage scan } \\
\text { (QTL-based) }\end{array}$ & {$[63]$} \\
\hline $\begin{array}{c}\text { Dyslexia/word- and } \\
\text { non-word reading, RAN }\end{array}$ & 1p36 (DYX8) & Locus-specific linkage analysis & [39] \\
\hline Dyslexia & Xq27.3 (DYX9) & Genome-wide linkage scan & [9] \\
\hline \multirow[t]{2}{*}{ Dyslexia } & & SNP-based linkage analysis & [64] \\
\hline & \multicolumn{2}{|l|}{ Other loci and genes } & \\
\hline \multirow{2}{*}{ Dyslexia/PD, SWR } & $21 q 22.3$ & $\begin{array}{l}\text { FISH/SNP 500k NspI microarray } \\
\text { (microdeletion-single family) }\end{array}$ & {$[65]$} \\
\hline & $\begin{array}{c}(P C N T, D I P 2 A, S 100 B, \text { and } \\
\text { PRMT2 })\end{array}$ & & \\
\hline \multirow[t]{2}{*}{ Dyslexia } & 15q21.2 (CYP19A1) & $\begin{array}{l}\text { FISH/SNP genotyping and } \\
\text { functional studies }\end{array}$ & [66] \\
\hline & (separate from $D Y X 1 C 1$ ) & & \\
\hline \multirow{2}{*}{ Dyslexia } & $4 q 13,16 \mathrm{p} 12,17 \mathrm{q} 22$ & Genome-wide linkage scan & [67] \\
\hline & suggestive locus at $7 q 36$ & & \\
\hline Mathematical (dis)abilities & $\begin{array}{l}\text { A score of a set of } 10 \text { SNPs in } \\
10 \text { loci, accounting for } 2.9 \% \text { of } \\
\text { the variance in math ability }\end{array}$ & $\begin{array}{l}\text { GWAS-Discovery (1200 cases) and } \\
\text { validation ( } 2356 \text { cases) cohorts } \\
\text { (UK population) }\end{array}$ & [68] \\
\hline
\end{tabular}

\footnotetext{
${ }^{1}$ Genomic loci as presented in the original corresponding article. SWR: single-word reading, PD: phonological decoding, RAN: rapid automatized naming, PA: phonological awareness, GWAS: Genome-Wide Association Study.
}

\subsection{Linkage Screens in Pedigrees}

A significant number of dyslexia candidate genes were identified through linkage studies in pedigrees. Reports on familial aggregation of dyslexia, characterized by an autosomal dominant inheritance pattern, continue to become published. These newer 
reports use a modern approach which combines traditional chromosomal mapping, using dense SNP-based-rather than microsatellite-based-genome-wide genotyping and linkage analysis, coupled with genome-wide gene expression and NGS technologies.

For instance, in 2017, Einarsdottir et al. reported the identification of NCAN (19p13), a putative novel dyslexia susceptibility gene. It is important, with this example, to highlight that, with the advent of new technologies of greater analytical potential, previously reported families with a clearly defined phenotype, but without a specific genetic diagnosis, can be revisited to offer novel findings. This dyslexia pedigree of Finnish origin, with eight affected cases across three generations [55], was anew subjected to genetic analysis using genotyping and linkage methods, in concert with next-generation whole-exome sequencing (WES) [69]. NCAN is expressed in several tissues, including several brain areas (Figure 1); its expression was significantly correlated with that of two other dyslexia candidate genes, namely GRIN2B and KIAA0319 (Table 2).

An impressive three-generation pedigree of Indian origin was reported by Naskar et al. in 2018; all alive individuals from generation II $(n=3)$, all of their offspring in generation III $(n=7)$ and almost all, but two, of the offspring in generation IV $(n=7)$ were affected with dyslexia in a pattern compatible with autosomal dominant inheritance. Genome-wide SNP genotyping combined with WES revealed several variants in the protocadherin gamma $(P C D H G)$ gene cluster (5q31.3) which encodes for alternative PCDHG transcripts owing to a large number of alternative $5^{\prime}$ exons. All identified variants clustered in the variable $5^{\prime}$ exons, which encode for the extracellular protocadherin domain. Protocadherins are predominantly expressed in the developing human brain and are known to play a role in neuronal connectivity, thus ensuring formation and maintenance of neural circuits [70].

One of the latest reports of this kind is by Grimm et al., who identified a novel dyslexia-associated gene, namely SPRY1 (4q28), after studying six out of nine affected individuals across a four-generation pedigree of German origin [71]. SPRY proteins are negative regulators of the Ras/MAPK/ERK pathway but, even though the authors showed that SPRY1 is expressed in all brain regions, it was not possible to explore the status of mutant SPRY1 expression in affected cases [71].

\subsection{Candidate Gene Association Studies}

There are two types of candidate gene association studies that have been published during the last two decades regarding genes that underlie genetic susceptibility to reading and mathematical abilities and disabilities. The first approach aims to explore established SLD genes in case-control cohorts of various ethnic origins, typically of Caucasian ancestry. The other approach aims to examine whether genes previously associated with reading and/or mathematical abilities in the general population can be valid in the context of an SLD diagnosis. Table 2 provides an updated list of past and recent publications that followed this study design, while summarizing their major findings.

For the purposes of this review, it is worth highlighting relatively recent studies that employed large sample sizes or were carried out by multicentered cross-linguistic initiatives. For instance, the European consortium NeuroDys performed a cross-linguistic case-control association study of dyslexia with data from more than 950 dyslexic individuals using targeted genotyping of selected markers in DYX1C1, DCDC2, KIAA0319, and the MRPL19/C2orf3 locus [72]. No SNP or haplotype surpassed statistical significance level, and none was associated with dyslexia in samples from more than one population, including populations speaking the same language (e.g., German). This may be potentially explained by differences in diagnosis between countries, genetic architecture heterogeneity among different populations, missing analysis of relevant traits, insufficient power due to the phenotypic heterogeneity of the disease, or combinations of the above [72].

In 2016, Müller and coworkers analyzed 16 SNPs in five genes affecting reading and spelling in the general population, in a German dyslexia case-control cohort [38]. On a single-marker level, no associations survived correction for multiple testing, but the observed risk alleles in KIAA0319 were in agreement with associations from both the 
general population, as well as other dyslexia studies [72]. No gene-specific haplotypes were associated with dyslexia in KIAA0319, DYX1C1, or DCDC2. When performing polygenic analysis, an increased number of risk alleles was observed within dyslexic cases compared to controls. The authors also demonstrated by in silico analyses on publicly available eQTL data that the SNPs residing in DCDC2, KIAA0319 and DYX1C1 affect the corresponding genes' expression, as well as the expression of a gene in the vicinity of $D C D C 2$, namely MRS2 [38].

In the study of Sánchez-Morán et al., the authors explored associations of three variants, one in each of three established dyslexia genes in 286 dyslexic children versus 1197 controls. Again, no single-marker association reached statistical significance, but pairwise SNP interaction between rs2274305 in DCDC2 and rs4504469 in KIAA0319 showed significant association with dyslexia as well as with dyslexia plus comorbid ADHD. In addition to the case-control design, these candidate SNPs were also associated with cognitive traits in the general population ( $n=3357)$ : rs2274305-DCDC2 with phoneme awareness (PA) and rapid automatized naming (RAN), DYX1C1 with word-reading and RAN, and rs4504469-KIAA0319 with word-reading, RAN, and syllable discrimination [73]. DCDC2 and KIAA0319 reside on the same locus, yet they are not in linkage disequilibrium; this points to independent, but synergistic, association, since a $D C D C 2$ risk haplotype interacts synergistically with a KIAA0319 haplotype, conferring higher risk in reading disability when both risk haplotypes occur together rather than separately [74].

A large cohort of more than 1500 unimpaired individuals was recently analyzed for genetic variants across 14 genes previously associated with dyslexia. Doust et al. performed gene-set-based analysis for reading impairment candidate genes and for the Gene Ontology biological pathway genes for 'axon guidance' and 'neuron migration'. The lack of replication of previous associations in this carefully characterized, yet unselected for SLD/dyslexia, cohort could be true or could be attributed to a number of other reasons: lack of statistical power to detect variants of small effect size, despite being one of the largest cohorts analyzed for reading abilities thus far, or sampling bias owing to participants recruitment from a twin registry [75].

The abovementioned studies are used as examples to illustrate that despite their undoubtedly careful design, statistically significant associations were still not reached or were, at best, nominal. Improvements, such as the incorporation of much larger numbers than past candidate gene studies and the recruitment of extremely carefully scrutinized participants across a number of reading and mathematical traits, left much of the genetic susceptibility puzzle of a common disease-common variant hypothesis unanswered. The field had to move on to hypothesis-free approaches; this advancement is reviewed in the following section.

Table 2. Summary of association studies of established or candidate SLD/dyslexia genes.

\begin{tabular}{|c|c|c|c|c|}
\hline $\begin{array}{c}\text { Phenotype } \\
\text { (Trait/Subphenotype) }\end{array}$ & Gene(s) & $\begin{array}{l}\text { Variant(s) Associated with } \\
\text { Phenotype or Trait }\end{array}$ & $\begin{array}{l}\text { Sample Size and } \\
\text { Study Design }\end{array}$ & Reference \\
\hline \multicolumn{5}{|c|}{ Genes Residing in Classical DYX Loci } \\
\hline $\begin{array}{c}\text { Dyslexia/PA, RAN, and } \\
\text { other traits }\end{array}$ & $D Y X 1 C 1$ & $\begin{array}{l}\text { rs11629841 and haplotypes of } \\
\text { rs11629841 with rs3743204 and } \\
\text { rs692691 }\end{array}$ & $\begin{array}{l}148 \text { nuclear families } \\
\text { (470 individuals) }\end{array}$ & [76] \\
\hline Dyslexia & DYX1C1 & No association & $\begin{array}{l}264 \text { nuclear families } \\
\text { (1153 individuals) }\end{array}$ & {$[77]$} \\
\hline Dyslexia & $D Y X 1 C 1$ & c. $1249 \mathrm{G}>\mathrm{T}$ coding variant & 191 trios & [78] \\
\hline $\begin{array}{l}\text { Dyslexia/short-term } \\
\text { memory }\end{array}$ & $D Y X 1 C 1$ & $\begin{array}{l}\text { c. }-3 \mathrm{G}>\mathrm{A} \text { and c. } 1249 \mathrm{G}>\mathrm{T} \\
\text { minor alleles haplotype }\end{array}$ & $\begin{array}{l}212 \text { nuclear families } \\
\text { (677 individuals) }\end{array}$ & [79] \\
\hline $\begin{array}{l}\text { Dyslexia/short-term } \\
\text { memory }\end{array}$ & DYX1C1 & $\begin{array}{c}\text { rs3743205/rs3743204/ } \\
\text { rs600753 haplotype in females }\end{array}$ & 366 trios & {$[80]$} \\
\hline
\end{tabular}


Table 2. Cont.

\begin{tabular}{|c|c|c|c|c|}
\hline $\begin{array}{c}\text { Phenotype } \\
\text { (Trait/Subphenotype) }\end{array}$ & Gene(s) & $\begin{array}{l}\text { Variant(s) Associated with } \\
\text { Phenotype or Trait }\end{array}$ & $\begin{array}{l}\text { Sample Size and } \\
\text { Study Design }\end{array}$ & Reference \\
\hline $\begin{array}{c}\text { Reading ability } \\
\text { (reading and spelling traits) }\end{array}$ & DYX1C1 & rs17819126 coding variant & $\begin{array}{l}284 \mathrm{DZ} \text { twins, } 164 \mathrm{DZ} \\
\text { twin families, } 143 \mathrm{MZ} \\
\text { twin families }\end{array}$ & [81] \\
\hline $\begin{array}{l}\text { Dyslexia/Reading ability } \\
\text { (12 cognitive traits) }\end{array}$ & $D C D C 2$ & 10/31 SNPs in DCDC2 & $\begin{array}{l}153 \text { nuclear families } \\
\text { (536 individuals) }\end{array}$ & [82] \\
\hline Dyslexia & $D C D C 2$ & No association & 396 trios & [83] \\
\hline $\begin{array}{c}\text { Dyslexia } \\
\text { (severe versus non-severe) }\end{array}$ & $D C D C 2$ & $\begin{array}{l}\text { rs793862, rs807701, rs } 80772 \\
\text { and intron-2 deletion }\end{array}$ & 72 cases / 184 controls & {$[84]$} \\
\hline $\begin{array}{c}\text { Reading ability } \\
\text { (7 reading and spelling traits) }\end{array}$ & $D C D C 2$ & $\begin{array}{l}21 \text { SNPs of which rs } 1419228 \\
\text { was associated with poorer } \\
\text { general reading performance }\end{array}$ & $\begin{array}{c}522 \text { twin families } \\
\text { (1067 individuals) } \\
\text { (unselected population) }\end{array}$ & [85] \\
\hline $\begin{array}{l}\text { Dyslexia/word-reading } \\
\text { and spelling }\end{array}$ & $D C D C 2$ & $\begin{array}{c}\text { rs793862 and rs807724 minor } \\
\text { alleles in SLD or } \\
\text { comorbid cases }\end{array}$ & $\begin{array}{l}225 \text { cases } / 442 \text { controls } \\
\text { (plus } 54 \text { comorbid } \\
\text { SLD/SLI/ADHD cases) }\end{array}$ & [86] \\
\hline $\begin{array}{l}\text { Dyslexia and mathematics } \\
\text { (numerical facts and } \\
\text { mental calculation) }\end{array}$ & $\begin{array}{l}D C D C 2 \text { and } \\
D Y X 1 C 1\end{array}$ & $\begin{array}{l}\text { c. }-3 \mathrm{G}>\mathrm{A}, \mathrm{c} .1249 \mathrm{G}>\mathrm{T} \text { in } \\
D Y X 1 C 1 \text { and intron-2 } \\
\text { deletion/STR in } D C D C 2\end{array}$ & $\begin{array}{l}180 \text { nuclear families } \\
\text { (581 individuals) }\end{array}$ & [87] \\
\hline $\begin{array}{l}\text { Dyslexia/ } 6 \text { traits of } \\
\text { reading ability }\end{array}$ & $D C D C 2$ & $\begin{array}{c}\text { Intron-2 STR alleles associated } \\
\text { with word- and non-word } \\
\text { repetition }\end{array}$ & $\begin{array}{l}303 \text { nuclear families } \\
\text { (973 individuals) }\end{array}$ & [88] \\
\hline Dyslexia & $D C D C 2$ & $\begin{array}{c}14 \text { SNPs of which several SNPs } \\
\text { and two haplotypes were } \\
\text { associated under different } \\
\text { models }\end{array}$ & 196 cases / 196 controls & [89] \\
\hline $\begin{array}{l}\text { Dyslexia/ } 6 \text { traits of } \\
\text { reading ability }\end{array}$ & $\begin{array}{l}D C D C 2 \text { and } \\
\text { KIAA0319 }\end{array}$ & $\begin{array}{c}5 \text { SNPs within KIAA0319 } \\
\text { Pairwise associations between } \\
\text { a DCDC2 and a KIAA0319 } \\
\text { variant }\end{array}$ & $\begin{array}{l}264 \text { nuclear families } \\
350 \text { cases } / 273 \text { controls }\end{array}$ & [90] \\
\hline $\begin{array}{c}\text { Reading abilities } \\
\text { (5 reading and spelling traits) }\end{array}$ & KIAA0319 & $\begin{array}{l}\text { rs2143340 associated with poor } \\
\text { reading and spelling }\end{array}$ & 6000 individuals & [91] \\
\hline $\begin{array}{l}\text { Dyslexia/ } 6 \text { traits of } \\
\text { reading ability }\end{array}$ & KIAA0319 & $\begin{array}{l}\text { rs9461045 associated with } \\
\text { dyslexia traits }\end{array}$ & $\begin{array}{l}264 \text { nuclear families } \\
\text { (of which } 126 \\
\text { comprised a severity } \\
\text { sample) }\end{array}$ & [92] \\
\hline $\begin{array}{l}\text { Dyslexia/Reading, spelling, } \\
\text { and phonological traits }\end{array}$ & $\begin{array}{l}D C D C 2 \text { and } \\
\text { KIAA0319 } \\
\text { NRSN1 }\end{array}$ & $\begin{array}{c}\text { rs6935076 in KIAA0319 } \\
\text { associated with dyslexia and } \\
\text { spelling and } 3 \text { SNPs in NRSN1 }\end{array}$ & $\begin{array}{l}291 \text { nuclear families } \\
\text { (of which } 165 \text { are trios) }\end{array}$ & [93] \\
\hline $\begin{array}{l}\text { General reading abilities } \\
\text { (word-reading and spelling) }\end{array}$ & $\begin{array}{l}\text { KIAA0319 and } \\
\text { CMIP }\end{array}$ & $\begin{array}{l}\text { rs2143340 in KIAA0319 and } \\
\text { rs6564903 in CMIP }\end{array}$ & $\begin{array}{l}225 \text { cases } / 442 \text { controls } \\
\text { (plus } 54 \text { comorbid } \\
\text { SLD/SLI/ADHD cases) }\end{array}$ & [86] \\
\hline Dyslexia and mathematics & ROBO1 & $\begin{array}{l}\text { rs333491 associated with } \\
\text { mental calculation accuracy }\end{array}$ & $\begin{array}{l}179 \text { nuclear families } \\
\text { (of which } \\
154 \text { comprised a } \\
\text { severity sample) }\end{array}$ & [94] \\
\hline $\begin{array}{c}\text { Dyslexia } \\
\text { Word-reading efficiency and } \\
\text { RAN }\end{array}$ & $\begin{array}{l}\text { KIAA0319L } \\
\text { KIAA0319L }\end{array}$ & $\begin{array}{c}\text { rs7523017 associated with } \\
\text { dyslexia } \\
\text { A four SNP-haplotype }\end{array}$ & $\begin{array}{l}291 \text { nuclear families } \\
156 \text { nuclear families }\end{array}$ & [95] \\
\hline
\end{tabular}


Table 2. Cont.

\begin{tabular}{|c|c|c|c|c|}
\hline $\begin{array}{c}\text { Phenotype } \\
\text { (Trait/Subphenotype) }\end{array}$ & Gene(s) & $\begin{array}{c}\text { Variant(s) Associated with } \\
\text { Phenotype or Trait }\end{array}$ & $\begin{array}{l}\text { Sample Size and } \\
\text { Study Design }\end{array}$ & Reference \\
\hline \multicolumn{5}{|c|}{ Other dyslexia-candidate genes } \\
\hline $\begin{array}{l}\text { Dyslexia/ } 6 \text { traits of } \\
\text { reading ability }\end{array}$ & CNTNAP2 & $\begin{array}{l}\text { rs2710102 associated with } \\
\text { non-word repetition }\end{array}$ & 188 trios & [96] \\
\hline $\begin{array}{l}\text { Dyslexia/ } 6 \text { traits of } \\
\text { reading ability }\end{array}$ & FOXP2 & $\begin{array}{l}\text { rs7782412 major allele } \\
\text { associated with non-word } \\
\text { repetition and real-word } \\
\text { reading efficiency }\end{array}$ & 188 trios & [96] \\
\hline $\begin{array}{c}\text { Dyslexia } \\
\text { (mismatch response) }\end{array}$ & $S L C 2 A 3$ & $\begin{array}{l}\text { rs } 4234898 \text { on chromosome } 4 \\
\text { associated with mismatch } \\
\text { response }\end{array}$ & $\begin{array}{c}200 \text { cases (discovery } \\
\text { set) } 186 \text { cases } \\
\text { (replication set) }\end{array}$ & [97] \\
\hline $\begin{array}{l}\text { Dyslexia/IQ and cognitive } \\
\text { processes and mathematics }\end{array}$ & GRIN2B & $\begin{array}{l}\text { rs5796555 and rs1012586 } \\
\text { associated with dyslexia }\end{array}$ & $\begin{array}{c}466 \text { nuclear families, of } \\
\text { which } 227 \text { comprised a } \\
\text { severity sample }\end{array}$ & [98] \\
\hline $\begin{array}{c}\text { Reading ability } \\
\text { (reading comprehension, } \\
\text { phonological memory) }\end{array}$ & $B D N F$ & $\begin{array}{l}\text { rs6265 associated with poorer } \\
\text { reading performance } \\
\text { rs6265 associated with } \\
\text { increased brain activity in } \\
\text { areas contributing to } \\
\text { phonological and reading } \\
\text { competence }\end{array}$ & $\begin{array}{l}81 \text { children } \\
94 \text { children }\end{array}$ & $\begin{array}{l}{[99]} \\
{[100]}\end{array}$ \\
\hline \multicolumn{5}{|c|}{ Dyslexia-associated gene panels } \\
\hline $\begin{array}{l}\text { Dyslexia/word-reading } \\
\text { and spelling }\end{array}$ & $\begin{array}{l}\text { DYX1C1, DCDC2, } \\
\text { KIAA0319, and } \\
\text { MRPL19/ } \\
\text { C2orf3 locus }\end{array}$ & No association & 958 cases $/ 1150$ controls & {$[72]$} \\
\hline Dyslexia & $\begin{array}{l}\text { MRPL19, C20RF3, } \\
\text { ROBO1, DCDC2, } \\
\text { KIAA0319, DYX1C1, } \\
\text { CNTNAP2, ATP2C2 } \\
\text { and CMIP }\end{array}$ & $\begin{array}{c}\text { rs807724 in } D C D C 2 \text { associated } \\
\text { with dyslexia }\end{array}$ & $\begin{array}{l}331 \text { cases / maximum } \\
363 \text { controls }\end{array}$ & [101] \\
\hline Dyslexia/spelling & $\begin{array}{l}\text { CYP19A1, DCDC2, } \\
\text { DIP2A, DYX1C1, } \\
\text { GCFC2 (C2orf3), } \\
\text { KIAA0319, MRPL19, } \\
\text { PCNT, PRMT2, } \\
\text { ROBO1 and S100B }\end{array}$ & $\begin{array}{l}\text { A non-synonymous SNP in } \\
D C D C 2 \text { (rs2274305) and a } \\
\text { non-coding SNP in S100B } \\
\text { (rs9722) associated } \\
\text { with dyslexia }\end{array}$ & $\begin{array}{l}361 \text { cases } / 261 \text { controls } \\
575 \text { affected, } 376 \\
\text { unaffected and } 511 \text { of } \\
\text { unknown status } \\
\text { (family-based) }\end{array}$ & [102] \\
\hline Dyslexia & $\begin{array}{l}D Y X 1 C 1, D C D C 2 \\
\text { KIAA0319, ROBO1 } \\
\text { and TDP2 }\end{array}$ & $\begin{array}{l}\text { Nominal associations only } \\
\text { (rs7765678 in DCDC2, } \\
\text { rs2038137 and rs6935076 } \\
\text { in KIAA0319) }\end{array}$ & 383 cases / 357 controls & {$[38]$} \\
\hline $\begin{array}{c}\text { Reading abilities } \\
\text { (Word/Non-word reading } \\
\text { fluency, PA, RAN) }\end{array}$ & $\begin{array}{l}\text { Top hits from } \\
\text { previous GWAS on } \\
\text { reading }(S L D) \text { and } \\
\text { language (SLI) } \\
\text { (dis)abilities }\end{array}$ & No association & $\begin{array}{l}307 \text { nuclear families } \\
\text { (483 children/ } \\
505 \text { adults) }\end{array}$ & [103] \\
\hline
\end{tabular}


Table 2. Cont.

\begin{tabular}{|c|c|c|c|c|}
\hline $\begin{array}{c}\text { Phenotype } \\
\text { (Trait/Subphenotype) }\end{array}$ & Gene(s) & $\begin{array}{l}\text { Variant(s) Associated with } \\
\text { Phenotype or Trait }\end{array}$ & $\begin{array}{l}\text { Sample Size and } \\
\text { Study Design }\end{array}$ & Reference \\
\hline Reading ability & $\begin{array}{c}\text { CYP19A1, DCDC2, } \\
\text { DYX1C1, GCFC2 } \\
(\text { C2orf3), KIAA0319, } \\
\text { MRPL19, ROBO1, } \\
\text { KIAA0319L DIP2A, } \\
\text { PRMT2, PCNT, } \\
\text { S100B, CNTNAP2 } \\
\text { and CMIP }\end{array}$ & $\begin{array}{l}\text { No single-marker association } \\
62 \text { SNPs-Gene-based SNP-set } \\
\text { associations were significant } \\
\text { for DYX1C1, DIP2A, CYP19A1 }\end{array}$ & $\begin{array}{l}1217 \text { old adults } \\
\quad(>70 \text { yrs) } \\
\text { (unimpaired) }\end{array}$ & [104] \\
\hline $\begin{array}{c}\text { Dyslexia } \\
\text { Word reading, RAN, and } \\
\text { syllable discrimination }\end{array}$ & $\begin{array}{l}\text { KIAA0319, DCDC2, } \\
\quad \text { and DYX1C1 }\end{array}$ & $\begin{array}{l}\text { No single-marker association } \\
\text { Pairwise SNP association with } \\
\text { dyslexia (rs2274305 in DCDC2 } \\
\text { and rs4504469 in KIAA0319) } \\
\text { rs2274305 in DCDC2 } \\
\text { rs57809907 in DYX1C1 } \\
\text { rs4504469 in KIAA0319 }\end{array}$ & $\begin{array}{l}286 \text { cases } / 1197 \text { controls } \\
3357 \text { individuals } \\
\text { (total cohort) }\end{array}$ & [73] \\
\hline Reading and spelling ability & $\begin{array}{c}\text { CMIP, CNTNAP2, } \\
\text { CYP19A1, } \\
\text { DCDC2, DIP2A, } \\
\text { DYX1C1, C2orf3, } \\
\text { KIAA0319, } \\
\text { KIAA0319L, } \\
\text { MRPL19, ROBO1, } \\
\text { PCNT, PRMT2 } \\
\text { and S100B }\end{array}$ & $\begin{array}{c}\text { No association } \\
\text { (>9500 SNPs and gene-based } \\
\text { SNP-sets) }\end{array}$ & $\begin{array}{l}1505 \text { individuals } \\
\text { (unimpaired) }\end{array}$ & [75] \\
\hline \multicolumn{5}{|c|}{ Other SLD domains } \\
\hline $\begin{array}{l}\text { Reading and mathematical } \\
\text { traits indicative of dyslexia } \\
\text { and dyscalculia, respectively }\end{array}$ & $\begin{array}{l}\text { 15q11.2(BP1-BP2)- } \\
\text { TUBGCP5, NIPA1, } \\
\text { NIPA2, CYFIP1 }\end{array}$ & $\begin{array}{l}\text { 15q11.2(BP1-BP2) deletion } \\
\text { CNV associated with worse } \\
\text { outcome in reading and } \\
\text { mathematical abilities }\end{array}$ & $\begin{array}{l}167 \text { controls, carriers of } \\
\text { neuropsychiatric CNVs }\end{array}$ & [43] \\
\hline Dysgraphia & $\begin{array}{l}D C D C 2, D Y X 1 C 1 \\
\text { KIAA0319 and } \\
\text { ROBO1 }\end{array}$ & $\begin{array}{c}\text { rs3743204 in DYX1C1 and } \\
\text { rs793842 in DCDC2 associated } \\
\text { with dysgraphia } \\
\text { measurements }\end{array}$ & 21 cases $/ 18$ controls & [105] \\
\hline
\end{tabular}

PA: phonological awareness, RAN: rapid automatized naming, SNP: single nucleotide polymorphism, cases = dyslexic cases, controls = unimpaired individuals, DZ: dizygotic (twins), MZ: monozygotic (twins), STR: short tandem repeat.

\section{High-Throughput Genome-Wide Analysis Continues to Shed Light on the Genetic Architecture of SLD}

3.1. Genome-Wide Association Studies (GWAS) and Polygenic Risk Scores (PRSs)

GWA studies are not hypothesis-driven, unlike candidate gene association studies that are designed with specific questions in mind, interrogating particular genes or genomic loci implicated in specific molecular pathways or biological processes hypothesized to be involved. Nevertheless, GWAS proved less successful than originally expected in helping to pinpoint SLD susceptibility loci, partly owing to the heterogeneous dyslexia phenotype and diagnostic/recruitment criteria used or to the small sample numbers analyzed compared to other neurodevelopmental/psychiatric phenotypes. Small sample sizes confer low detection power for common variants with small effect sizes, especially considering the stringent statistical correction for multiple testing over hundreds of thousands or millions of variants that needs to be taken into account. To compensate, genome-wide screening of the general population for DNA variants associated with reading, arithmetic and language abilities as heritable traits attracted intense research interest; these were viewed as "intermediate phenotypes", or quantitative traits acting as endophenotypes, determined by a genetic background that potentially also underlies SLD etiology. 
Reading skill as a quantitative trait was explored for the first time by applying a GWAS approach using the extremes of its continuous distribution. Two groups, low versus high reading ability, comprising a total sample of 1500 children, were genotyped using a low-density SNP microarray ( 100 k). Top candidate SNPs showing the largest allele frequency differences between extreme-ends groups were validated in an independent sample of 900 age-matched children. Of those, ten SNPs showed nominally significant association with continuous variation in reading ability [106]. Since this seminal effort, a significant number of studies have been conducted, several of which focused on variants with pleiotropic effects in both reading and language traits (Table 3) [107-109]. We believe that the most recent one deserves highlighting for two reasons. First, the authors studied reading disability predictors, namely RAN and rapid alternating stimulus, in a sample of more than 1300 Hispanic-American and African-American young individuals. Second, they found, for the first time in a GWAS design, genome-wide significance for a variant located on the upstream region of a long non-coding RNA (lncRNA) gene, namely RPL7P34, $30 \mathrm{~kb}$ upstream of RNLS (10q23.31). It was suggested that this variant resides on an enhancer element that potentially interacts with an active RNLS transcription start site in the hippocampus, owing to chromatin's three-dimensional structure. The variant was further associated with structural variation (cortical volume) in the right inferior parietal lobule of an independent multi-ethnic sample [110]. Currently, it remains largely unknown how non-coding regions of the genome may impact reading traits; the identification of variants in gene regulatory regions, as recently demonstrated for ARHGEF39 in SLI [111], or the role of post-transcriptional (e.g., miRNA-based) regulation of gene expression, is undoubtedly an exciting new field of research.

Coming to the context of dyslexia, one of the first GWAS, albeit of a very small scale in comparison to current standards (200 cases for discovery and 186 for replication, tested for a limited number of markers (300k)), identified rs4234898 on chromosome 4 as a transacting regulatory variant for $S L C 2 A 3$ which resides on chromosome 12 . SLC2A3 codes for a glucose transporter in neurons, and its reduced expression in lymphoblastoid cell lines was shown to be significantly associated with the minor rs4234898 allele. It was suggested that $S L C 2 A 3$ might act as a susceptibility gene for an electrophysiological endophenotype in dyslexic children with glucose transport deficits, namely mismatch negativity (MMN) or mismatch response. MMN serves as a measure for speech perception and automatic speech deviance which has been found impaired in dyslexic children [97]. This mismatch response endophenotype was later shown to associate with common variants in DYX1C1 [112], unlike common variants in DCDC2 and KIAA0319 [113].

The largest GWAS for dyslexia-specific traits was recently published, with data generated for almost 3500 reading-impaired and typically developing children of European ancestry from nine countries speaking six different languages. Genome-wide significance was observed with RAN for four variants on 18q12.2, within MIR924HG (rs17663182), and a suggestive association on 8q12.3 within NKAIN3. It is of note that MIR924 is predicted to regulate candidate dyslexia susceptibility genes like MRPL19 and KIAA0319L, as observed via in silico analysis of putative miR-924 binding sites [114]. The same group performed a polygenic risk score (PRS) analysis between eight reading traits and different neuropsychiatric disorders (ADHD, ASD, major depressive disorder and schizophrenia), educational attainment, and neuroimaging phenotypes (seven brain areas) and found a significant genetic overlap between some of these reading traits and educational attainment and, to a lesser extent, with ADHD [114]. This initiative led to an even larger dyslexia case-control GWAS of almost 2300 cases and 6300 controls, a subset of which overlapped with the same authors' 2019 paper [26]. No novel genome-wide significant associations emerged at single-marker level; gene-based analysis from the top SNP association signals revealed VEPH1 (3q25) as a top candidate gene, but no specific pathways showed significant enrichment [26].

Actually, the first study assessing the reading ability of non-dyslexic children and adolescents with the use of PRS analysis was published in 2017. The authors in this study 
utilized GWAS data from $>5800$ cases and used educational attainment (=years of education completed) to predict reading performance in English. They calculated a PRS-heritability estimate of reading ability of almost $5 \%$, based only on common variants. This estimate represents approximately $7 \%$ of the total heritability for reading ability $\left(\mathrm{h}^{2}=70 \% ; 5 \% / 70 \%\right)$ evaluated through twin studies [115]. However, if calculating the PRS-heritability estimate using an SNP-heritability estimate, which was shown to account for $22 \%$ of the total genetic variance [116], then the PRS-heritability estimate can explain a significant 23\% (5\%/22\%) of the genetic variance observed for reading ability, an estimate that remained significant after accounting for age-specific cognitive ability and family socioeconomic status [115].

The use of PRSs is a rather young addition to the armor of (statistical) tools to evaluate the genetic component of complex traits, even more so for complex cognitive skills like reading performance; yet, we can already foresee its potential. Given its inherent nature (as DNA variants do not change by age), knowing the individual genetic differences in reading ability perhaps may prove useful in the early prediction of reading problems like dyslexia. This will require large multicentered initiatives of tens of thousands of participants. However, because language transparency is an important issue in assessing dyslexia, perhaps large GWAS with participants using the same language would be powerful enough to explore the applicability of PRS further, an approach already tested by Gialluisi et al. in their 2019 analysis [114].

The first GWAS study conducted to exclusively assess mathematical ability and disability was published ten years ago; two groups of children from the Twins Early Development Study, with high versus low mathematical ability (600 individuals per group), served as the discovery cohort, and 2356 individuals, spanning the entire distribution of mathematical ability, were used for validation purposes. Out of 10 top candidate SNPs, rs11225308 (MMP7), rs363449 (GRIK1), and rs17278234 (DNAH5) were the variants most significantly associated with mathematical ability. Because the effect sizes of these 10 SNPs were small, the authors created an 'SNP-set score' for each of the 2356 individuals, which accounted for $2.9 \%$ of the variance in their sample [68]. In fact, by using this SNP-set score, it was shown that one third of children who harbored $\geq 50 \%$ of the identified risk alleles were nearly twice as likely to be in the lowest-performing $15 \%$ of the mathematical ability distribution [68]. This score was later correlated with certain environmental factors, demonstrating likely gene $\times$ environment interactions [117].

Subsequently, in a sample of almost 700 dyslexic cases and more than 1400 controls, available GWAS data were reanalyzed to associate genetic variation specifically with dyscalculia. The authors found rs133885 in MYO18B to be strongly correlated with mathematical abilities in the dyslexia sample and, to a lesser extent, the general population. A significantly lower depth of the right intraparietal sulcus, an anatomical brain region involved in numerical processing in humans, was associated with rs133885 [118]. However, this association was not supported in the subsequent analysis of a much larger collection of 5144 individuals from four cohorts of European ancestry, 329 of which were diagnosed with dyslexia [119]. A third GWAS aiming to explore the genetic contributions to mathematical ability was conducted in a general population sample of 602 adolescents/young adults with excellent verbal ability but either high or low mathematical ability. The marker with the largest effect size was rs789859, located in the promoter of $F A M 43 A$ and in high linkage disequilibrium with two SNPs in the adjacent LSG1 gene (3q29), a region previously linked to learning difficulties and autism [120]. Although the encoded protein's function remains obscure, FAM43A was found expressed in the brain, cerebellum and spinal cord [120].

One GWAS was conducted exclusively on the purpose to assess mathematical ability in the general population of Chinese elementary school students in 2017. Two discovery and one replication groups were used, totaling almost 1600 individuals. Sample metaanalysis revealed four linked SNPs in SPOCK1 associated on a genome-wide significance level with a decrease in math scores on two examination periods [121]. Interestingly, mutations in SPOCK1, which encodes for the extracellular proteoglycan testican-1, have 
been associated with ID and microcephaly in humans, whereas Spock1 mouse models have demonstrated strong gene expression in the brain as well as its role in neurogenesis [121].

By now, it has become clear that because GWAS are designed to target common variants, often in non-coding, regulatory or even intergenic regions, they do not necessarily directly reveal the true effect of likely pathogenic variants, as it would be expected in the case of rare coding variants. On the other hand, initial genome-wide genotyping platforms were designed based on Caucasian genome frequencies and most of what we currently know about reading and mathematical abilities and disabilities originates from studies of individuals of Caucasian ancestry, despite the fact that SLD affects populations globally and irrespective of language. Thus, we are largely unaware of the genetic architecture of SLD across populations and ethnic ancestries. GWAS, despite setting the grounds for unbiased genome-wide interrogations, most often than not, have returned results that could be hardly replicated. This has been attributed either to small effect sizes of common variants, especially for quantitative traits such as reading-associated traits, small sample sizes to reveal statistically powerful associations or even to lack of consensus in SLD diagnosis. Hence, alternative yet complementary methods, as those described in the next paragraphs, have significantly contributed in the delineation of the genetic architecture of SLD during the last years.

\subsection{Copy-Number Variants (CNVs)}

Part of the missing heritability of SLD may be also caused by structural variants. CNVs have been extensively explored in other neurodevelopmental disorders, such as ASD, ID [122-124], Tourette Syndrome [125,126], and SLI [127]; results for SLD have been inconclusive. On one hand, recent analyses of dyslexia cohorts indicate that rare, large CNVs may not confer a significant burden [122,128]. On the other hand, rare de novo or inherited deletions or duplications, such as the Xq21.3 region bearing PCDH11X [129], 17q21.31 harboring NSF [130], and 15q11.2(BP1-BP2) harboring four highly conserved genes (Table 3) $[43,44]$, have been reported in cases with SLD. Earlier, a father and his three affected sons were found to carry a submicroscopic deletion (at least $\sim 176 \mathrm{~kb}$ ) on 21q22.3, encompassing the $3^{\prime}$ region of $P C N T$, genes DIP $2 A$ and $S 100 B$ and the $5^{\prime}$ upstream sequence of PRMT2. The deletion perfectly segregated with dyslexia and standard scores for phonological decoding and single-word reading of below -1.5 to -2 standard deviations [65]. As described later (Section 3.3), a non-coding variant in $5100 B$ was also associated with spelling performance in a German family set [102].

Different loci have been found to harbor deletions and duplications in patients with various clinical presentations and comorbid math comprehension difficulties. Children with the 22q11.2 deletion syndrome show considerable difficulties in procedural calculation and word problem solving due to difficulties in understanding and representing numerical quantities, despite relatively normal reading performance [131]. A 22q11.2 deletion spanning LCR22-4 to LCR22-5 interval was found in an 11-year-old girl with normal intelligence, number sense deficit, normal results in spelling and reading tests and social contact difficulties [132]. A severely affected girl with X-linked myotubular myopathy and math difficulties was found to carry an inherited $661 \mathrm{~kb}$ Xq28 microduplication with a skewed X chromosome inactivation pattern [133]. If we exclude syndromic cases, reports on individuals presenting exclusively with mathematical impairments who bear rare or novel de novo or inherited CNVs are truly scarce. An increase of CNVs of the Olduvai protein domain on 1q21 (NBPF15), previously known as DUF1220, appear to be involved in human brain size and evolution and may determine the mathematical aptitude ability of both sexes [134]. This genetic locus is highly expressed in brain regions with high cognitive function [135], but it has not been studied in the context of mathematical disabilities.

Last but not least, a recent study from the Icelandic population investigated the effect of 15q11.2(BP1-BP2) deletion in cognitive, structural and functional correlations of dyslexia and mathematical disabilities. This CNV was previously associated with cognition deficits in non-neuropsychiatric cases with a history of SLD [43]. Later, Ulfarsson et al. showed 
that the deletion conferred high risk in either dyslexia or dyscalculia, but the risk was even higher in the combined dyslexia plus dyscalculia phenotype; all deletion carriers performed worse on a battery of tests assessing reading and mathematical abilities. In the same sample, structural magnetic resonance imaging (sMRI) and functional MRI (fMRI) were performed, demonstrating that smaller left fusiform gyrus and altered activation in the left fusiform and left angular gyrus also associated with the 15q11.2 deletion [44]. These brain areas are involved in the retrieval of mathematical facts, the usage of learned facts and the performance of arithmetic operations [136-138]. This anatomical and functional brain differentiation could be one cause of the greater risk observed for the combined phenotype in deletion carriers.

Either de novo or transmitted, these structural variations may produce a yet unknown spectrum of disturbances on genomic, transcriptomic and proteomic level, for instance haploinsufficiency in the case of deletion or overexpression in the case of duplication $[139,140]$, consequently also affecting subsequent protein-protein interactions; these are hypotheses that warrant further investigation. Interestingly, the 15q11.2(BP1-BP2) duplication carriers do not show significant cognitive impairments, compared to 15q11.2(BP1-BP2) deletion carriers, and are comparable to no-CNV controls [44]. This fact supports the role of haploinsufficiency for the genes mapped on this region, particularly CYFIP1, which was shown to be involved in neuronal development [141].

\subsection{Next-Generation Sequencing}

It is unclear how much of the missing heritability of SLD could be attributed to rare or de novo variants of moderate or high effect, even though this issue has been extensively studied with respect to ID, ASD and developmental delay [142-144]. With the emergence of NGS technology, the identification of rare variants could help fill in some of the missing pieces of the puzzle. Sequencing data have only recently begun to emerge for SLD, supporting the influence of certain genomic regions on reading performance and related disabilities. As expected, the first efforts concentrated and sources were allocated on the validation of previously established or suspected dyslexia genes in various populations.

Originally mapped through a submicroscopic deletion on 21q22.3 in a dyslexia family [65], S100B was one of 11 genes to be scrutinized for rare variants using targeted NGS in more than 900 dyslexia cases from Finland and Germany; a 3' UTR variant (rs9722), located on or adjacent to in silico predicted miRNA target sites, was associated with spelling performance in the German family set. Moreover, a nonsynonymous variant in DCDC2 (rs2274305) was associated with severe spelling deficiency in the same sample set [102]. A similar approach was applied to a subsequent next-generation targeted sequencing effort by Adams et al., who selected dyslexia-associated candidate genes to be screened in 96 affected, unrelated subjects of European ancestry from the Colorado Learning Disability Research Center (CLDRC). These cases were selected based on a CLDRC-derived discriminant score indicating impairment in reading ability [145]. The authors searched for rare, likely disrupting, variants and calculated a statistically significant increase in the frequency of observed mutations in dyslexia cases-compared to data from 1000 Genomes Project-in two loci: 7q32.1 harboring the adjacent genes CCDC136 and FLNC (19 missense variants) and 6p22 harboring DCDC2 and KIAA0319 (74 missense variants). The data indicate that these regions must have an influence on reading performance, even though not all of the above-mentioned genes show detectable expression in the brain (Figure 1) [145].

The first whole-exome sequencing (WES) study was published in 2015 by Einarsdottir et al. in an effort to identify the genetic basis of a familial form of dyslexia with likely complete penetrance in an extended three-generation pedigree with 12 confirmed dyslexic and four uncertain cases. Through several filtering steps on WES data, a small heterozygous in/del variant was identified in CEP63, namely c.686-687delGCinsTT; its transmission was compatible with autosomal dominant inheritance. This rare variant codes for a nonsynonymous change in a highly evolutionarily conserved amino acid (p.R229L), which was in silico predicted to alter the protein's tertiary structure [146]. As discussed later 
(Section 6), CEP63 is a centrosomal protein involved in microtubule organization and, even though it is ubiquitously expressed (Figure 1), brain-specific isoforms may be affected by such rare variants. It still remains to be seen whether CEP63 variants are linked to dyslexia in additional cases.

Several other reports have also demonstrated that dyslexia-associated genes encode proteins with structural and functional roles in cilia (Section 6) [147-153]. Recently, rare variants were identified in two genes related to motile cilia structure and function, namely dynein axonemal heavy chain 5 (DNAH5) and dynein axonemal heavy chain 11 (DNAH11). This represents the first whole-genome sequencing (WGS) analysis in literature of two unrelated dyslexia cases, with situs inversus and ADHD symptomatology [154]. Even though direct links between visceral and functional brain asymmetry are lacking, visceral asymmetry (e.g., situs inversus) is comorbid, at least in some cases, with psychiatric and neurodevelopmental disorders [155]. Although it could not be proven unequivocally that the identified variants in DNAH5 and DNAH11 cause susceptibility to dyslexia, these two genes represent good candidates for further studies.

Overall, the most recent studies that have used state-of-the-art methodology to look for either likely pathogenic CNVs or rare variants in isolated families have provided clues for the implication of novel genes. Family-based studies continue to be a powerful method to unravel the genetic basis of dyslexia [146]. However, variations in reported loci do not explain, so far, but a small percentage of the genetic component of SLD. Consequently, much of the heritability of learning-related disorders remains unaccounted for. Perhaps the answer is not "hiding" exclusively in single, rare variants that remain yet to be identified, but also in gene $\times$ gene and higher-order chromatin interactions or epigenetic regulatory mechanisms and ways that the environment can determine the (epi)genome [156]. It is of note that epigenome-wide association studies have not been reported yet.

Table 3. Recent studies (2013-2021) reporting novel genomic loci and genes associated with SLD and related traits using high-throughput methodologies.

\begin{tabular}{|c|c|c|c|}
\hline $\begin{array}{c}\text { Phenotype } \\
\text { (Trait/Subphenotype) }\end{array}$ & Gene(s) & Experimental Approach & Reference \\
\hline $\begin{array}{l}\text { Reading abilities } \\
\text { (reading, spelling) }\end{array}$ & Suggestive associations only & GWAS (meta-analysis) & [108] \\
\hline $\begin{array}{l}\text { Dyslexia or Dyslexia+SLI } \\
\text { comorbidity }\end{array}$ & $\begin{array}{c}\text { ZNF385D } \\
\text { (comorbid cases only) }\end{array}$ & GWAS (case-control) & [107] \\
\hline $\begin{array}{c}\text { Dyslexia } \\
\text { (phonological coding skill) }\end{array}$ & $\begin{array}{c}\text { Suggestive linkage and } \\
\text { suggestive associations only }\end{array}$ & GWAS (case-control) & [67] \\
\hline Dyslexia & PCDH11X & $\begin{array}{l}\text { CNV + SNP microarray } \\
\text { (11 families) }\end{array}$ & [129] \\
\hline Dyslexia/Dyscalculia & $\begin{array}{c}\text { 15q11.2(BP1-BP2) harboring } \\
\text { TUBGCP5, NIPA1, NIPA2 } \\
\text { and CYFIP1 }\end{array}$ & $\begin{array}{l}\text { Targeted CNV and } \\
\text { neuroimaging analysis }\end{array}$ & {$[43,44]$} \\
\hline $\begin{array}{c}\text { Reading abilities } \\
\text { (reading, spelling, } \\
\text { phonological awareness) }\end{array}$ & RBFOX2, CCDC136/FLNC & GWAS (meta-analysis) & [109] \\
\hline Dyslexia & NSF & $\begin{array}{l}\text { CNV + SNP microarray } \\
\text { (10 families) }\end{array}$ & [130] \\
\hline Dyslexia & CEP63 & WES (single family) & [146] \\
\hline Dyslexia & S100B & Targeted NGS (11 genes panel) & [102] \\
\hline Dyslexia & CCDC136 and FLNC & $\begin{array}{c}\text { Targeted NGS-11 loci harboring } \\
25 \text { genes }\end{array}$ & [145] \\
\hline
\end{tabular}


Table 3. Cont.

\begin{tabular}{|c|c|c|c|}
\hline $\begin{array}{c}\text { Phenotype } \\
\text { (Trait/Subphenotype) }\end{array}$ & Gene(s) & Experimental Approach & Reference \\
\hline Dyslexia & NCAN & $\begin{array}{l}\text { SNP microarray and linkage } \\
\text { analysis, WES } \\
\text { (single family) }\end{array}$ & [69] \\
\hline Dyslexia & PCDHG gene cluster & $\begin{array}{l}\text { SNP microarray and WES } \\
\text { (single family) }\end{array}$ & [70] \\
\hline Dyslexia / 8 cognitive traits & $\begin{array}{c}\text { MIR924HG } \\
\text { (associated with RAN) }\end{array}$ & GWAS (case-control) & [114] \\
\hline Dyslexia & $\begin{array}{c}V E P H 1 \\
\text { (gene-based analysis) }\end{array}$ & GWAS (case-control) & [26] \\
\hline Dyslexia & SPRY1 & $\begin{array}{l}\text { SNP microarray and } \\
\text { linkage analysis } \\
\text { (single family) }\end{array}$ & [71] \\
\hline $\begin{array}{l}\text { Reading ability } \\
\text { (word reading) }\end{array}$ & LINC00935 and CCNT1 & GWAS (case-control) & [157] \\
\hline Mathematical abilities & MYO18B & GWAS (case-control) & [118] \\
\hline Mathematical abilities & $\begin{array}{c}\text { rs789859 intergenic to } L S G 1 \text { and } \\
\text { FAM43A (3q29) }\end{array}$ & $\begin{array}{l}\text { GWAS (high versus low } \\
\text { mathematical ability) }\end{array}$ & [120] \\
\hline Mathematical abilities & SPOCK1 & GWAS (meta-analysis) & [121] \\
\hline
\end{tabular}

SLI: specific language impairment, GWAS: Genome-Wide Association Study, WES: whole exome sequencing, CNV: copy number variant, SNP: single nucleotide polymorphism.

\section{Comorbidity and Genetic Correlation with Other Neurodevelopmental Phenotypes}

Since the "generalist genes" hypothesis was proposed [41], it has become common ground, and recent emerging evidence also supports, that neurodevelopmental disorders share, to a certain extent, a common genetic background. High-impact studies support the pleiotropic or even antagonistic actions of genes and their variation on complex phenotypes, with a particular focus on psychiatric disorders [158,159]. Cross-disorder analyses aim at identifying transdiagnostic variants that could point eventually toward common underlying traits (e.g., cognitive, imaging), molecular pathways, and even symptoms or environmental risk factors [160]. Pleiotropy is mainly manifested via loci harboring genes that show brain-specific expression; thus, these genes are expected to be particularly important in neuronal development, with potential implications for better disease classification and management or future treatment interventions. Prominent examples in the field include schizophrenia and bipolar disorder [161], ASD and ADHD [162,163], Tourette Syndrome (TS) and Obsessive-Compulsive Disorder (OCD) [164,165], and, more recently, OCD and anorexia [166], or TS and ADHD/ASD [167].

As highlighted in the introduction, individuals with SLD show symptoms of ADHD, SLI, or other conditions, but it remains unclear whether these comorbid with SLD or are secondary problems deriving from the impairments caused by SLD. Reading and language are both viewed as highly heritable traits that are likely to share common genetic and/or neurobiological influences [168]. Shared genetic contributions between reading and language performance have been explored in several studies using candidate gene association analyses or GWAS meta-analysis [101,103,108,109]. For instance, Luciano et al. found strong associations with variants in 21q11.2 (ABCC13 pseudogene), 19p13.3 (DAZAP1), 1p36.33 (CDK11B, CDK11A) and 1p36.11 (RCAN3) [108]. Gialluisi et al. identified suggestive associations in 7q32.1 (CCDC136/FLNC) and 22q12.3 (RBFOX2) [109]. Others failed to find supportive evidence [103].

As mentioned earlier, in their latest report, Gialluisi et al. interrogated GWAS data from a very large sample of dyslexic cases and controls and apart from identifying VEPH1 (3q25) as the top candidate gene, their analysis highlighted the association of dyslexia with 
ADHD, and an even stronger association with intelligence, bipolar disorder and schizophrenia [26], further supporting the notion of cross-disorder susceptibility between psychiatric and neurodevelopmental phenotypes. Of course, the hypothesis of a shared genetic background between dyslexia and ADHD, which occurs in approximately $25-40 \%$ of dyslexic individuals [169], has been a subject of extensive study. Comorbid cases exhibit more extensive and severe neuropsychological weakness and symptoms manifestation [170,171]. It was also shown that the heritability of reading disabilities was significantly higher in dyslexic individuals who also met criteria for ADHD [171]. Numerous recent studies support the SLD-ADHD common etiology hypothesis: Field et al. reported common loci implicated in both dyslexia and ADHD [67]. Mascheretti et al. found evidence for a DCDC2 SNP (rs793862) via gene $\times$ gene interaction with KIAA0319 with hyperactivity/impulsivity, a finding replicated in two independent samples [172], that was soon after also reported for the inattentive subphenotype [73].

Taking a step further, Verhoef et al. interrogated ADHD-related PRSs in relation to reading-related abilities in a large sample of children ( 6000 individuals) from the UK Avon Longitudinal Study of Parents and Children (ALSPAC) in an effort to find evidence for shared genetic factors between ADHD and reading. Notably, polygenic ADHD risk was associated not only with reading but also with language-related abilities, further strengthening the hypothesis of shared genetic etiology between reading, language and ADHD [173]. In a GWAS study of $\sim 2300$ dyslexia cases and $\sim 6300$ controls, PRS analysis highlighted anew the correlation of ADHD with dyslexia and an even stronger association of dyslexia with two psychiatric disorders (schizophrenia and bipolar disorder) [26]. Price et al. performed a similar analysis starting from a GWAS on two children's cohorts ( 5250 individuals) aiming to explore the genetic architecture of reading; they used PRS from publicly available datasets on neurodevelopmental and psychiatric disorders and found a statistically significant association between ADHD and reading, as well as an overlap of 22 reading-associated genes previously implicated in ASD [157]. In fact, the relationship between dyslexia and ASD has not been extensively studied and data on the prevalence of ASD in cohorts ascertained for reading disabilities are most likely nonexistent [174].

Despite preliminary evidence, however, it is too soon to say whether the observed shared genetic susceptibility between dyslexia and ADHD can be also reflected in brain's disease-related anatomical structures and functional alterations. In two recent sMRI metaanalyses on grey matter differences in isolated ADHD versus dyslexia, no shared neural correlates were found $[175,176]$. On the other hand, when ADHD and dyslexia coexist, alterations (decreased cortical thickness) can be observed in brain regions relevant for both disorders, supporting the common etiology hypothesis; the same can be said for comorbid cases who exhibit reduced brain activity (during fMRI tasks) in regions associated with deficits in either isolated ADHD or dyslexia [176].

In Table 5 we provide the updated list of genes that have been, so far, implicated in different SLD domains, along with basic information on their biological role (Section 6). In parallel, we indicate which candidate SLD genes have shown association with other neurodevelopmental disorders, as curated in public databases (e.g., SFARI Gene database; [177]) and in literature.

\section{Emerging Data from Neuroimaging Genetic Studies}

Brain scans using modern technologies have provided ground-breaking insights into the workings of the human brain. Various MRI techniques have been most popularly used to visualize and explore: (a) structural abnormalities [e.g., cortical surface area (cSA) and cortical thickness; grey matter (GM) and white matter (WM) density and volumes] (sMRI), (b) alterations in structural connectivity between brain areas (DTI), and (c) functional abnormalities either in resting state or while performing (a) task(s) (reading-related, phonological, auditory, semantic, working-memory, visual-spatial, attentional, mixed) (fMRI). 
Dyslexia has been associated with various anatomical and functional changes in the brain. In brief, total brain volume, GM and WM volume, total intracranial volume, cortical thickness and cSA, global and local brain asymmetries, level of gyrification, and to a lesser extent sulci configuration, have been under intensive research, not necessarily reaching an agreement regarding how these global brain measures are affected in dyslexia [15]. Regarding brain activity alterations, fMRI analyses show that cerebral hypoactivation seems to prevail over hyperactivity $[37,178]$.

Interestingly, alterations seen in pre-reading children at risk for dyslexia are in agreement with results from children diagnosed with dyslexia [37]. This favors the idea that atypical brain development likely associated with dyslexia could be present within the first years of life and that dyslexia deficits may result from altered structural connectivity [179]. Moreover, faster WM development was observed in good versus poor readers from prereading to beginning-to-read and to fluent-reading stages, as well as a positive association between WM maturation and reading development [180]. Such data from neuroimaging studies in infants and pre-reading children, in concert with the high heritability estimates for reading abilities and disabilities, could suggest that dyslexia susceptibility genes may be involved in atypical neural migration and/or axonal growth during early (even in utero) brain development.

In the recently published, massive neuroimaging genetics meta-analysis study of the ENIGMA Consortium, it was shown that general cognitive function and educational attainment are the two cognitive traits that exhibit the most significant positive genetic correlation with cSA. According to the radial unit hypothesis, the expansion of cSA is driven by the proliferation of neural progenitor cells. Common variants explained $34 \%$ of the variation in total cSA; importantly, these variants have been associated with altered gene regulatory activity in neural progenitor cells during fetal development [181]. However, no GWAS and sMRI data from learning (dis)abilities and/or dyslexia studies were used in this meta-analysis, presumably because ENIGMA does not host an SLD working group.

Nevertheless, an extremely informative review on the neuroimaging genetics of dyslexia was published in 2017 by Mascheretti and co-workers; therein, the authors have done meticulous work to compile all available information from neuroimaging genetic association studies in established and candidate dyslexia genes, either in dyslexic cases or in the general population, covering studies published between 2010 and 2016 [37]. Thus, it is beyond the scope and the allocated space of the present article to review all dyslexia neuroimaging genetic studies anew. Instead, we have summarized findings published only in the last five years, with a focus on dyslexia and reading abilities (Table 4).

Among the most recent studies that led to the identification of novel dyslexia candidate genes, it is interesting to highlight that an intronic SNP located in CEP63 was associated with WM volume in both right and left hemispheres of healthy individuals, as well as with reading comprehension scores [146]. The cluster of significant effect overlapped with a brain region previously found to be significant for SNPs within DYX1C1 and KIAA0319 [182]. Moreover, the right temporoparietal region associated with rs1064395 in NCAN and also overlapped with a region previously associated with the dyslexia susceptibility genes KIAA0319, DYX1C1 and MRPL19, as well as CEP63 [69,183]. The 15q11.2(BP1-BP2) deletion CNV, previously associated with a larger corpus callosum [43], was also associated with a smaller left fusiform gyrus as well as with altered activation; decreased activation was also observed for the left angular gyri, regions shown to associate with language and arithmetic tasks (Table 4) [44].

Pinel and Dehaene used fMRI to investigate heritability for brain activation while participants performed mental calculations. Posterior superior parietal lobules (SPL), right intraparietal sulcus (IPS), a left superior frontal region and left inferior parietal cortex (IPC) were under genetic influence [184]. Regarding dyscalculia, it was shown that dyscalculic children have decreased GM and WM volumes in the frontoparietal network, which might be associated with impaired arithmetic processing skills, whereas the WM volume decrease in parahippocampal areas may have an influence on fact retrieval and spatial memory 
processing $[185,186]$. Brain activation patterns of children with dyslexia, dyscalculia and comorbid dyslexia/dyscalculia were highly similar in how they deviated from neural activation patterns in control children when performing arithmetic tasks while undergoing fMRI [187]. Bulthe et al. recently revealed a significant deficit in number representations in temporal, parietal and frontal regions and a hyper-connectivity in visual brain regions in adults with dyscalculia [188].

Despite the progress in unravelling the polygenic nature of SLD, even with the latest molecular genomics approaches, combined with unprecedented technological advances in neuroimaging, we still lack a comprehensive and united understanding of SLD, whereas the field of neuroimaging genetics is in its infancy. One proposal to utilize neuroimaging genetics to identify biological causes of dyslexia would be to perform MRI imaging before the onset of reading acquisition, ideally in populations enriched with children at-risk of dyslexia (due to family history or parents or siblings with dyslexia). Given that the individual's genetic makeup does not change in lifetime, a longitudinal design that would allow neuroimaging follow-up of these at-risk children until they reach reading (dis)abilities could be ideal in determining both the predictive role of brain scanning and the causal role of genetics. We reproduce this idea by Ramus et al. and expand it by adding genetics into the picture, yet we cannot but emphasize all the increased demands and challenges such a study design would impose [15]. However, it is of equally crucial importance to more deeply comprehend the neurobiology underlying these complex phenotypes and how established and emerging genes, and their variation, determine and affect neuronal development, respectively; we briefly touch on this subject in the following section.

Table 4. Recent (2015-presently) neuroimaging genetic studies reporting associations between genes and genomic loci associated with reading and mathematical (dis)abilities. The list is ordered based on evidence of association for genomic loci previously associated with SLD (that is, from replicated associations to newer evidence).

\begin{tabular}{|c|c|c|c|c|}
\hline $\begin{array}{c}\text { Phenotype } \\
\text { (Trait/Subphenotype) }\end{array}$ & $\begin{array}{c}\text { Gene } \\
\text { (Associated Variant) }\end{array}$ & Association Outcome & $\begin{array}{l}\text { Neuroimaging } \\
\text { Technique }\end{array}$ & $\begin{array}{l}\text { Reference } \\
\text { (Population) }\end{array}$ \\
\hline $\begin{array}{c}\text { Dyslexia } \\
\text { (poor reading } \\
\text { comprehension) }\end{array}$ & $\begin{array}{c}D C D C 2 \\
\text { READ1 element } \\
\text { (RU2Short allele) }\end{array}$ & $\begin{array}{l}\text { Higher R hemisphere } \\
\text { connectivity: Stronger functional } \\
\text { connectivity between R } \\
\text { insula/IFG and R SMG }\end{array}$ & $\begin{array}{c}\text { fMRI } \\
\text { (resting state) }\end{array}$ & $\begin{array}{c}{[189]} \\
\text { (Hispanic- and } \\
\text { African-Americans) }\end{array}$ \\
\hline Dyslexia & $\begin{array}{l}\text { KIAA0319 } \\
(\mathrm{rs} 6935076)\end{array}$ & $\begin{array}{l}\text { Positive correlation between the } \\
\text { number of minor alleles and the } \\
\text { degree of neural variability in } \\
\text { primary auditory cortex (cases } \\
\text { and controls) }\end{array}$ & MEG & $\begin{array}{c}\text { [190] } \\
\text { (US population) }\end{array}$ \\
\hline $\begin{array}{l}\text { Typically developing } \\
\text { children without } \\
\text { mathematical training }\end{array}$ & $\begin{array}{l}\text { ROBO1 } \\
\text { (9 SNPs) }\end{array}$ & $\begin{array}{l}\text { GM pattern of the R parietal } \\
\text { cortex (IPS and SPL) }\end{array}$ & sMRI & $\begin{array}{c}\text { [191] } \\
\text { (German } \\
\text { population) }\end{array}$ \\
\hline Dyslexia & $\begin{array}{c}\text { NRSN1 } \\
\text { (3 SNPs) } \\
\text { FOXP2 } \\
\text { (6 SNPS) } \\
\text { CNTNAP2 } \\
\text { (7 SNPS) } \\
\text { CMIP } \\
\text { (6 SNPS) }\end{array}$ & $\begin{array}{l}\text { NRSN1: GM volume in R dorsal } \\
\text { parieto-occipital cortex, L lateral } \\
\text { occipital cortex, L } \\
\text { temporo-occipital fusiform } \\
\text { cortex (visual word form } \\
\text { area)/WM volume in L } \\
\text { post-central cortex } \\
\text { FOXP2: GM volume in L medial } \\
\text { superior frontal gyrus } \\
\text { CNTNAP2: WM volume in L } \\
\text { cerebral and cerebellar } \\
\text { peduncles } \\
\text { CMIP: WM volume in } \mathrm{R}+\mathrm{L} \\
\text { portions of cerebellum }\end{array}$ & sMRI & $\begin{array}{c}\text { [192] } \\
\text { (German } \\
\text { population) }\end{array}$ \\
\hline
\end{tabular}


Table 4. Cont.

\begin{tabular}{|c|c|c|c|c|}
\hline $\begin{array}{c}\text { Phenotype } \\
\text { (Trait/Subphenotype) }\end{array}$ & $\begin{array}{c}\text { Gene } \\
\text { (Associated Variant) }\end{array}$ & Association Outcome & $\begin{array}{l}\text { Neuroimaging } \\
\text { Technique }\end{array}$ & $\begin{array}{l}\text { Reference } \\
\text { (Population) }\end{array}$ \\
\hline Dyslexia + Dyscalculia & $\begin{array}{l}\text { 15q11.2(BP1-BP2) } \\
\text { (deletion CNV) }\end{array}$ & $\begin{array}{l}\text { Smaller L fusiform gyrus (less } \\
\text { GM) and less WM in R } \\
\text { cerebellum, R paracentral lobule } \\
\text { and L STL } \\
\text { Decreased L fusiform and L } \\
\text { angular gyri activation }\end{array}$ & $\begin{array}{l}\text { sMRI } \\
\text { fMRI }\end{array}$ & $\begin{array}{c}{[44]} \\
\text { (Icelandic } \\
\text { population) }\end{array}$ \\
\hline $\begin{array}{l}\text { Reading comprehension } \\
\text { scores }\end{array}$ & $\begin{array}{c}\text { CEP63 } \\
\text { (rs7619451) }\end{array}$ & $\begin{array}{l}\text { Increased WM volume in } \mathrm{R}+\mathrm{L} \\
\text { hemisphere (temporoparietal } \\
\text { region) of healthy individuals }\end{array}$ & sMRI & $\begin{array}{c}\text { [146] } \\
\text { (Swedish } \\
\text { population) }\end{array}$ \\
\hline $\begin{array}{l}\text { Typically developing } \\
\text { individuals }\end{array}$ & $\begin{array}{c}N C A N \\
\text { (rs1064395) }\end{array}$ & $\begin{array}{c}\text { Increased WM volume in } \mathrm{R}+\mathrm{L} \\
\text { temporoparietal and } \mathrm{L} \text { inferior } \\
\text { frontal brain regions (young } \\
\text { adults) } \\
\text { Increased GM volume in } \mathrm{R}+\mathrm{L} \\
\text { cingulate, } \mathrm{R} \text { superior frontal and } \\
\mathrm{R} \text { inferior parietal regions } \\
\text { (infants) }\end{array}$ & sMRI & $\begin{array}{c}\text { [69] } \\
\text { (Finnish and } \\
\text { Swedish } \\
\text { population) }\end{array}$ \\
\hline $\begin{array}{l}\text { Typically developing } \\
\text { individuals } \\
\text { (reading ability) } \\
\text { Brain activity (in } \\
6 \text { ROIs) - Typically } \\
\text { developing children } \\
\text { (phonological skills, } \\
\text { reading competence) }\end{array}$ & $\begin{array}{c}\text { BDNF } \\
\text { (rs6265 or p.V66M) }\end{array}$ & $\begin{array}{l}\text { Greater activation in reading- } \\
\text { related regions (fusiform gyrus, } \\
\text { L IFG, L STG) and greater } \\
\text { activation in the hippocampus } \\
\text { Increased brain activity in ROI } 2 \\
\text { (bilateral hippocam- } \\
\text { pus/parahippocampal } \\
\text { gyrus/fusiform } \\
\text { gyrus / cerebellum) and ROI } 3 \text { (L } \\
\text { middle frontal } \\
\text { gyrus/IFG/thalamus) }\end{array}$ & $\begin{array}{l}\text { fMRI } \\
\text { fMRI }\end{array}$ & $\begin{array}{c}\text { [99] } \\
\text { (US } \\
\text { population-86.4\% } \\
\text { of Caucasian origin) } \\
\text { [100] } \\
\text { (US } \\
\text { population-86.2\% } \\
\text { of Caucasian origin, } \\
\text { or which 86.2\% } \\
\text { overlap with } \\
\text { samples from [99]) }\end{array}$ \\
\hline $\begin{array}{l}\text { Typically developing } \\
\text { children and young } \\
\text { adults (RAN) }\end{array}$ & $\begin{array}{c}\text { rs1555839 } \\
(30 \mathrm{~kb} \text { upstream of } R N L S)\end{array}$ & $\begin{array}{l}\text { Decreased cortical volume in the } \\
\text { R IPL }\end{array}$ & sMRI & {$[110]$} \\
\hline
\end{tabular}

CNV: copy number variant, R: right, L: left, WM: white matter, GM: grey matter, fMRI: functional MRI, sMRI: structural MRI, STL: superior temporal lobe, SPL: superior parietal lobe; IPL: inferior parietal lobe, IPS: intraparietal sulcus, IFG: inferior frontal gyrus, MFG: middle frontal gyrus, STG: superior temporal gyrus, SMG: supramarginal gyri, READ1: regulatory element associated with dyslexia 1, ROI: region of interest, RAN: rapid automatized naming, MEG: magnetoencephalography.

\section{A Glimpse on the Biological Background of SLD}

The polygenic nature of SLD points to the existence of multiple causal pathways, much like most other neurodevelopmental disorders, where each variant contributes by a small effect to the total phenotypic variation. As observed via electrophysiological and neuroimaging studies in infants and pre-reading children, brain alterations predate reading ability or reading impairment, supporting the hypothesis that variants functioning in dyslexia susceptibility genes lead to atypical neural migration and/or axonal growth during early, most likely in utero, brain development [193,194].

However, the underlying neurodevelopmental causes of dyslexia are not fully understood. Original post-mortem neuroanatomical studies on dyslexia cases, conducted almost 35 years ago, were later followed by neuroimaging studies in humans and functional (knock-down and knock-out) animal studies. These studies lend support to the hypothesis that neuronal migration disturbances during development lead to misplacement of neurons, likely resulting in changes in white and grey matter $[35,195]$. The pathways that have emerged by now are relevant to neuronal migration and positioning, axon guidance regulating brain connectivity, dendritic growth, synaptic plasticity/transmission, cell adhesion, and sex hormone biology (Table 5) [36]. ROBO1, KIAA0319, DCDC2, DYX1C1 gene products are mostly implicated in neurite outgrowth, neural connectivity, migration and development (Figure 2).

Although prior evidence from functional studies lend support to the idea that abnormal neuronal migration constitutes the neurobiological basis of dyslexia, which largely 
explains why this has been the most often cited hypothesis, in their recent review Guidi et al. advocate otherwise. The authors critically evaluated the hypothesis of neuronal migration and concluded that the evidence from histopathological and imaging studies in humans and functional studies in animal models is not robust enough to support it. The readers are encouraged to consult Table 1 from Guidi et al. for a thorough review on functional studies on key dyslexia genes conducted in several animal species and cell lines; therein, the authors have compiled data from reports in favor of the neuronal migration hypothesis as well as from studies refuting it [196].

Original studies also failed to find associations supporting the neuronal migration, axon guidance or steroid hormone-related pathways $[75,104,109,128]$. Thus, it emerges that although researchers have been keen to place many of the dyslexia candidate genes in a theoretical molecular/cellular model network involved in neuronal migration and neurite outgrowth, it seems unlikely that there is just a single explanatory model that connects all dyslexia-associated proteins on the molecular level. Rather, several etiological cascades contributing to dyslexia are likely to exist [35].

In fact, several reports have demonstrated that many dyslexia candidate genes, such as DYX1C1 and DCDC2, have a reported structural or functional role in cilia $[147,149,197]$. Loss-of-function mutations in DYX1C1 and DCDC2 have been found in patients with ciliopathies: $D Y X 1 C 1$ in cases of primary ciliary dyskinesia, with ciliary defects also confirmed in mouse and zebrafish models [148], and DCDC2 in patients with nephronophthisis-related ciliopathy, inherited deafness and neonatal sclerosing cholangitis [150-153]. Conversely, we are unaware whether patients with such ciliopathies, caused by DYX1C1 and DCDC2 mutations, show symptoms of SLD or other cognitive impairments.

Other dyslexia candidate genes, such as PCNT, CEP63 and TUBGCP5, are involved in centrosome and basal body biology (Table 5) $[65,146,198]$. TUBGCP5, PCNT and CEP63 are three of many centrosomal proteins involved in microtubule organization and even though they are ubiquitously expressed, brain-specific isoforms may be affected by rare variants. Centrosomal proteins are important in proper cell cycle progression; PCNT and CEP63 deficiencies were separately shown to cause microcephalic primordial dwarfism in humans $[199,200]$, and a Seckel syndrome-like phenotype in mice, characterized by mitotic errors leading to p53-dependent neuronal progenitor cell death [201]. Bieder et al. used human iPSCs to derive a neuroepithelial stem cell line and showed that genes related to cilia were significantly enriched among genes upregulated during neuronal differentiation; importantly, a significant number of dyslexia-associated genes were detected by RNAsequencing, of which seven, including DYX1C1, were upregulated, adding further support to the hypothesis of cilia dysregulation [202].

Left-right brain asymmetry defects have been proposed as an anatomical basis to neurodevelopmental disorders, such as ASD and dyslexia, possibly mediated by ciliary dysfunction [155]. Although the aforementioned proteins are associated structurally or functionally with primary cilia, microtubules and centrosomes, it remains unclear by which molecular mechanisms aberrations in their expression can lead to cognitive impairment. For an extensive presentation on the role of genes associated with cilia homeostasis/function and neurodevelopment/brain development, the readers are referred to excellent past reviews on the subject $[36,155,203]$.

A gene's expression or protein function is subject to genetic variation, and current methodologies allow us to observe this level of complexity with unprecedented detail by using genome-wide approaches. Still, genes do not act alone; they form pathways that interwind, creating higher-order networks and determining biological processes that are difficult to disentangle, especially in the case of complex traits lacking clear-cut diagnostic definitions, like dyslexia. Looking expectantly into the future, the ultimate goal for unravelling the biological mechanisms that contribute to and/or define SLD is the presymptomatic identification and development of age-adjusted precision intervention strategies, tailored to each individual's language, educational demands and other social and psychological factors [110]. 
Table 5. Expression status in brain, cellular localization, and biological role of established and suspected genes associated with SLD susceptibility; the list is sorted by chromosome.

\begin{tabular}{|c|c|c|c|c|c|c|c|c|}
\hline $\begin{array}{l}\text { Chromosomal } \\
\text { Locus }^{1}\end{array}$ & Gene $^{2}$ & Gene Name & SLD Domain & $\begin{array}{l}\text { Association with Other } \\
\text { Neurodevelopmental } \\
\text { Disorder(s) }\end{array}$ & $\begin{array}{l}\text { Brain Expression } \\
\text { Status }^{4}\end{array}$ & $\begin{array}{c}\text { Subcellular } \\
\text { Localization }^{4}\end{array}$ & $\begin{array}{c}\text { Biological Role }^{4} \\
\text { (Protein Function, } \\
\text { Biological Process) }\end{array}$ & Reference $^{5}$ \\
\hline $1 \mathrm{p} 34.3$ & KIAA0319L & KIAA0319 like & Dyslexia & & Yes (Low specificity) & $\begin{array}{l}\text { Nucleoli, plasma } \\
\text { membrane, Golgi } \\
\text { apparatus }\end{array}$ & $\begin{array}{l}\text { Axon guidance-interaction } \\
\text { with RTN4R }\end{array}$ & \\
\hline $2 \mathrm{p} 12$ & MRPL19 & $\begin{array}{l}\text { Mitochondrial } \\
\text { ribosomal protein L19 }\end{array}$ & Dyslexia & & Yes (Low specificity) & Mitochondrion & $\begin{array}{l}\text { Ribosome biogenesis (39S } \\
\text { subunit), rRNA processing } \\
\text { Mitochondrial protein } \\
\text { synthesis }\end{array}$ & {$[53]$} \\
\hline $2 \mathrm{p} 12$ & $\begin{array}{l}\text { GCFC2 } \\
\text { (C2orf3) }\end{array}$ & $\begin{array}{l}\text { GC-rich sequence } \\
\text { DNA-binding factor } 2\end{array}$ & Dyslexia & & Yes (Low specificity) & $\begin{array}{l}\text { Nucleoplasm, } \\
\text { nucleolus }\end{array}$ & $\begin{array}{l}\text { Pre-mRNA splicing, intron } \\
\text { turnover and RNA } \\
\text { processing }\end{array}$ & [205] \\
\hline $3 p 12.3$ & ROBO1 & $\begin{array}{l}\text { Roundabout guidance } \\
\text { receptor } 1\end{array}$ & $\begin{array}{l}\text { Dyslexia }+ \\
\text { Mathematical } \\
\text { abilities }\end{array}$ & ASD & Yes (Low specificity) & Plasma membrane & $\begin{array}{l}\text { Axon guidance receptor } \\
\text { regulating connections } \\
\text { between brain hemispheres } \\
\text { Neuronal axon guidance } \\
\text { receptor for SLIT1 and SLIT2 } \\
\text { (rat, Drosophila) }\end{array}$ & [206] \\
\hline $3 q 22.2$ & CEP63 & Centrosomal protein 63 & Dyslexia & & Yes (Low specificity) & Centrosomal & $\begin{array}{c}\text { Cilium structure and } \\
\text { function - centrosome } \\
\text { duplication and cell cycle } \\
\text { progression }\end{array}$ & \\
\hline 3q25.31-q25.32 & VEPH1 & $\begin{array}{l}\text { Ventricular zone } \\
\text { expressed PH domain } \\
\text { containing } 1\end{array}$ & Dyslexia & & Low & $\begin{array}{l}\text { Nucleoplasm, } \\
\text { nucleoli, cytosol }\end{array}$ & $\begin{array}{l}\text { Interacts with TGF- } \beta \\
\text { receptor type-1 (TGFBR1) } \\
\text { and inhibits dissociation of } \\
\text { activated SMAD2 from } \\
\text { TGFBR1, impeding its } \\
\text { nuclear accumulation and } \\
\text { resulting in impaired TGF- } \beta \\
\text { signaling. May also affect } \\
\text { FOXO, Hippo and Wnt } \\
\text { signaling }\end{array}$ & \\
\hline $4 q 28.1$ & SPRY1 & $\begin{array}{l}\text { Sprouty RTK signaling } \\
\text { antagonist } 1\end{array}$ & Dyslexia & & Yes (Low specificity) & $\begin{array}{l}\text { Nucleoplasm, Golgi } \\
\text { apparatus, cytosol, } \\
\text { plasma membrane }\end{array}$ & $\begin{array}{c}\text { Negative feedback regulators } \\
\text { of growth factors signaling - } \\
\text { inhibits the RTK-Ras-MAPK } \\
\text { pathway (mouse) }\end{array}$ & {$[207,208]$} \\
\hline
\end{tabular}


Table 5. Cont

\begin{tabular}{|c|c|c|c|c|c|c|c|c|}
\hline $\begin{array}{l}\text { Chromosomal } \\
\text { Locus }^{1}\end{array}$ & Gene $^{2}$ & Gene Name & SLD Domain & $\begin{array}{l}\text { Association with Other } \\
\text { Neurodevelopmental } \\
\text { Disorder(s) }^{3}\end{array}$ & $\begin{array}{l}\text { Brain Expression } \\
\text { Status }^{4}\end{array}$ & $\begin{array}{l}\text { Subcellular } \\
\text { Localization }^{4}\end{array}$ & $\begin{array}{c}\text { Biological Role } \\
\text { (Protein Function, } \\
\text { Biological Process) }\end{array}$ & Reference $^{5}$ \\
\hline $5 q 31.3$ & PCDHG & $\begin{array}{l}\text { Protocadherin gamma } \\
\quad \text { (gene cluster) }\end{array}$ & Dyslexia & & Yes (Enhanced) & Plasma membrane & $\begin{array}{l}\text { Neuronal cell adhesion - } \\
\text { formation and maintenance } \\
\text { of neural circuits }\end{array}$ & \\
\hline $5 q 31.2$ & SPOCK1 & $\begin{array}{l}\text { SPARC (osteonectin), } \\
\text { cwcv and kazal like } \\
\text { domains } \\
\text { proteoglycan } 1\end{array}$ & Dyscalculia & & Yes (Enhanced) & $\begin{array}{c}\text { Extracellular } \\
\text { (secreted to blood) }\end{array}$ & $\begin{array}{l}\text { Mouse neurogenesis and } \\
\text { post-injury axonal growth - } \\
\text { Mouse embryonic } \\
\text { development }\end{array}$ & \\
\hline $6 \mathrm{p} 22.3$ & $\begin{array}{l}\text { NRSN1 } \\
(V M P)\end{array}$ & Neurensin 1 & Dyslexia & & Yes (Enriched) & $\begin{array}{c}\text { Plasma membrane, } \\
\text { cytosol }\end{array}$ & $\begin{array}{l}\text { Neural organelle transport, } \\
\text { transduction of nerve signals, } \\
\text { nerve growth. May play a } \\
\text { role in neurite extension }\end{array}$ & \\
\hline $6 \mathrm{p} 22.3$ & $D C D C 2$ & $\begin{array}{l}\text { Doublecortin domain } \\
\text { containing } 2\end{array}$ & $\begin{array}{l}\text { Dyslexia }+ \\
\text { Mathematical } \\
\text { abilities }+ \\
\text { Dysgraphia }\end{array}$ & ADHD, SLI & Yes (Low specificity) & $\begin{array}{l}\text { Microtubules, } \\
\text { mitotic spindle, } \\
\text { centriolar satellite, } \\
\text { cytosol }\end{array}$ & $\begin{array}{c}\text { Embryonic neuronal } \\
\text { migration (rat) } \\
\text { Ciliary functions - Length } \\
\text { and signaling of primary cilia } \\
\text { in neurons (rat, C. elegans) } \\
\text { Glutamatergic synaptic } \\
\text { transmission (mouse) }\end{array}$ & $\begin{array}{l}{[82,147,209,} \\
210]\end{array}$ \\
\hline $6 \mathrm{p} 22.3$ & KIAA0319 & KIAA0319 & Dyslexia & ADHD, SLI & Yes (Enriched) & $\begin{array}{l}\text { Extracellular } \\
\text { (secreted) }\end{array}$ & $\begin{array}{c}\text { Embryonic neuronal } \\
\text { migration } \\
\text { Growth and differentiation of } \\
\text { dendrites (rat) } \\
\text { Inhibition of axon growth }\end{array}$ & [211-213] \\
\hline
\end{tabular}


Table 5. Cont

\begin{tabular}{|c|c|c|c|c|c|c|c|c|}
\hline $\begin{array}{l}\text { Chromosomal } \\
\text { Locus }^{1}\end{array}$ & Gene $^{2}$ & Gene Name & SLD Domain & $\begin{array}{l}\text { Association with Other } \\
\text { Neurodevelopmental } \\
\text { Disorder(s) }^{3}\end{array}$ & $\begin{array}{l}\text { Brain Expression } \\
\text { Status }{ }^{4}\end{array}$ & $\begin{array}{l}\text { Subcellular } \\
\text { Localization }^{4}\end{array}$ & $\begin{array}{l}\text { Biological Role } \\
\text { (Protein Function, } \\
\text { Biological Process) }\end{array}$ & Reference ${ }^{5}$ \\
\hline $7 \mathrm{q} 31.1$ & FOXP2 & Forkhead box P2 & & SLI, ASD, ADHD & Low in adult brain & Nucleoplasm & $\begin{array}{l}\text { Transcriptional repressor - } \\
\text { May also play a role in } \\
\text { developing neural, } \\
\text { gastrointestinal and } \\
\text { cardiovascular tissues. Can } \\
\text { act with CTBP1 to } \\
\text { synergistically repress } \\
\text { transcription. Plays a role in } \\
\text { synapse formation by } \\
\text { regulating SRPX2 levels. } \\
\text { Involved in neural } \\
\text { mechanisms mediating the } \\
\text { development of speech } \\
\text { and language. }\end{array}$ & \\
\hline $7 \mathrm{q} 35$ & CNTNAP2 & $\begin{array}{c}\text { Contactin associated } \\
\text { protein } 2\end{array}$ & Dyslexia & SLI, TS, ASD, ID, CD & Yes (Enhanced) & Plasma membrane & $\begin{array}{l}\text { Cell adhesion (neurexin) } \\
\text { participating in the } \\
\text { organization of myelinated } \\
\text { axons - localization of } \mathrm{K}^{+} \\
\text {channels within } \\
\text { differentiating axons (rat) - } \\
\text { axon potential propagation }\end{array}$ & {$[214,215]$} \\
\hline $7 q 32.1$ & CCDC136 & $\begin{array}{l}\text { Coiled-coil domain } \\
\text { containing } 136\end{array}$ & Dyslexia & & Yes (Enriched) & $\begin{array}{l}\text { Golgi apparatus, } \\
\text { plasma membrane }\end{array}$ & $\begin{array}{c}\text { Acrosome formation in } \\
\text { spermatogenesis and in } \\
\text { fertilization (rat). Insufficient } \\
\text { data about biological role in } \\
\text { the CNS. }\end{array}$ & \\
\hline $7 q 32.1$ & FLNC & Filamin C & Dyslexia & $\begin{array}{l}\text { Association trend for } \\
\text { ADHD }\end{array}$ & Yes (Low specificity) & $\begin{array}{c}\text { Plasma membrane, } \\
\text { cytosol }\end{array}$ & $\begin{array}{c}\text { Large actin-cross-linking } \\
\text { protein (mouse). Insufficient } \\
\text { data about biological role in } \\
\text { the CNS }\end{array}$ & [109] \\
\hline 11p14.1 & $B D N F$ & $\begin{array}{c}\text { Brain derived } \\
\text { neurotrophic factor }\end{array}$ & Dyslexia & & Yes (Enhanced) & $\begin{array}{l}\text { Nuclear speckles, } \\
\text { mitochondria, } \\
\text { extracellular } \\
\text { (secreted) }\end{array}$ & $\begin{array}{c}\text { Activates signaling cascades } \\
\text { downstream of NTRK2. } \\
\text { Survival and differentiation } \\
\text { of neuronal populations of } \\
\text { CNS. (mouse-rat) }\end{array}$ & \\
\hline
\end{tabular}


Table 5. Cont

\begin{tabular}{|c|c|c|c|c|c|c|c|c|}
\hline $\begin{array}{l}\text { Chromosomal } \\
\text { Locus }^{1}\end{array}$ & Gene $^{2}$ & Gene Name & SLD Domain & $\begin{array}{l}\text { Association with Other } \\
\text { Neurodevelopmental } \\
\text { Disorder(s) }{ }^{3}\end{array}$ & $\begin{array}{l}\text { Brain Expression } \\
\text { Status }^{4}\end{array}$ & $\begin{array}{l}\text { Subcellular } \\
\text { Localization }^{4}\end{array}$ & $\begin{array}{l}\text { Biological Role } \\
\text { (Protein Function, } \\
\text { Biological Process) }\end{array}$ & Reference $^{5}$ \\
\hline 12p13.1 & GRIN2B & $\begin{array}{l}\text { Glutamate ionotropic } \\
\text { receptor NMDA type } \\
\text { subunit 2B }\end{array}$ & Dyslexia & ASD & Yes (Enriched) & $\begin{array}{l}\text { Plasma membrane, } \\
\text { endosome, lysosome, } \\
\text { cytoskeleton }\end{array}$ & $\begin{array}{l}\text { Component of NMDA } \\
\text { receptor (excitatory synaptic } \\
\quad \text { transmission) } \\
\text { Neuronal pattern formation, } \\
\text { channel function, formation } \\
\text { of dendritic spines in } \\
\text { hippocampal pyramidal cells }\end{array}$ & \\
\hline $12 q 13.12$ & CCNT1 & Cyclin T1 & $\begin{array}{l}\text { Word } \\
\text { reading }\end{array}$ & & Yes (Low specificity) & Nucleoplasm & $\begin{array}{l}\text { Regulatory subunit of the } \\
\text { cyclin-dependent kinase pair } \\
\text { (CDK9/cyclin-T1) complex }\end{array}$ & [157] \\
\hline \multirow{3}{*}{$15 \mathrm{q} 11.2$} & TUBGCP5 & $\begin{array}{l}\text { Tubulin gamma } \\
\text { complex associated } \\
\text { protein } 5\end{array}$ & \multirow{3}{*}{$\begin{array}{l}\text { Dyslexia }+ \\
\text { Dyscalculia }\end{array}$} & ASD, ID & Yes (Low specificity) & $\begin{array}{l}\text { Centrosome, } \\
\text { cytoplasm }\end{array}$ & $\begin{array}{l}\text { Microtubule nucleation at the } \\
\text { centrosome }\end{array}$ & \\
\hline & NIPA1 & $\begin{array}{l}\text { NIPA magnesium } \\
\text { transporter } 1\end{array}$ & & ID & Yes (Enhanced) & $\begin{array}{l}\text { Early endosome, } \\
\text { plasma membrane }\end{array}$ & $\begin{array}{c}\mathrm{Mg}^{2+} \text { transporter (mouse, } \\
\text { Xenopus) }\end{array}$ & \\
\hline & CYFIP1 & $\begin{array}{l}\text { Cytoplasmic FMR1 } \\
\text { interacting protein } 1\end{array}$ & & ID & Yes (Low specificity) & $\begin{array}{c}\text { Cytoplasm, } \\
\text { perinuclear region }\end{array}$ & $\begin{array}{l}\text { Actin-binding. Axon } \\
\text { outgrowth. Formation of } \\
\text { membrane ruffles and } \\
\text { lamellipodia. (rat) } \\
\text { Binds to the mRNA cap - } \\
\text { translational repression } \\
\text { activity of FMR1 in } \\
\text { brain (mouse) }\end{array}$ & {$[141,216,217]$} \\
\hline $15 q 21.3$ & $\begin{array}{l}\text { DNAAF4 } \\
(D Y X 1 C 1)\end{array}$ & $\begin{array}{l}\text { Dynein axonemal } \\
\text { assembly factor } 4\end{array}$ & $\begin{array}{c}\text { Dyslexia + } \\
\text { Mathematical } \\
\text { abilities + } \\
\text { Dysgraphia }\end{array}$ & & Yes (Low specificity) & $\begin{array}{l}\text { Plasma membrane, } \\
\text { cytosol and nucleus }\end{array}$ & \begin{tabular}{l}
\multicolumn{1}{c}{ Embryonic neuronal } \\
$\quad$ migration (rat). \\
Cilia structure and motility \\
(mouse, zebrafish, human) \\
$\quad$ Estrogen receptors \\
$\quad$ regulation (rat)
\end{tabular} & {$[149,218,219]$} \\
\hline
\end{tabular}


Table 5. Cont

\begin{tabular}{|c|c|c|c|c|c|c|c|c|}
\hline $\begin{array}{l}\text { Chromosomal } \\
\text { Locus }^{1}\end{array}$ & Gene $^{2}$ & Gene Name & SLD Domain & $\begin{array}{l}\text { Association with Other } \\
\text { Neurodevelopmental } \\
\text { Disorder(s) }\end{array}$ & $\begin{array}{c}\text { Brain Expression } \\
\text { Status }^{4}\end{array}$ & $\begin{array}{c}\text { Subcellular } \\
\text { Localization }^{4}\end{array}$ & $\begin{array}{l}\text { Biological Role } \\
\text { (Protein Function, } \\
\text { Biological Process) }\end{array}$ & Reference $^{5}$ \\
\hline $15 q 21.2$ & CYP19A1 & $\begin{array}{c}\text { Cytochrome P450 } \\
\text { family } 19 \text { subfamily A } \\
\text { member } 1\end{array}$ & Dyslexia & & Yes (Low specificity) & $\begin{array}{l}\text { Endoplasmic } \\
\text { reticulum membrane, } \\
\text { mitochondria }\end{array}$ & $\begin{array}{c}\text { A cytochrome P450 } \\
\text { monooxygenase implicated } \\
\text { in steroid hormone } \\
\text { metabolism (sexual brain } \\
\text { differentiation, synaptic } \\
\text { plasticity, dendritic and } \\
\text { axonal growth) }\end{array}$ & [66] \\
\hline $17 q 21.31$ & NSF & $\begin{array}{l}\text { N-ethylmaleimide } \\
\text { sensitive factor, vesicle } \\
\text { fusing ATPase }\end{array}$ & Dyslexia & & Yes (Enhanced) & $\begin{array}{l}\text { Golgi apparatus, } \\
\text { cytosol }\end{array}$ & $\begin{array}{l}\text { Hydrolase (substrates: ATP } \\
\quad \text { and } \mathrm{H}_{2} \mathrm{O} \text { ) } \\
\text { Vesicle-mediated transport }\end{array}$ & \\
\hline $18 \mathrm{p} 11.21$ & $M C 5 R$ & $\begin{array}{l}\text { Melanocortin } 5 \\
\text { receptor }\end{array}$ & & & $\begin{array}{l}\text { No (human brain) } \\
\text { Yes (mouse \& pig) }\end{array}$ & Plasma membrane & $\begin{array}{l}\text { G-protein coupled receptor } \\
\text { for MSH and ACTH - } \\
\text { possible mediator of the } \\
\text { immunomodulation } \\
\text { properties of melanocortins }\end{array}$ & \\
\hline $18 \mathrm{q} 21.31$ & NEDD4L & $\begin{array}{c}\text { NEDD4 like E3 } \\
\text { ubiquitin protein ligase }\end{array}$ & Dyslexia & & Yes (Low specificity) & $\begin{array}{l}\text { Golgi apparatus, } \\
\text { endosome, } \\
\text { cytoplasm }\end{array}$ & $\begin{array}{c}\text { Accepts ubiquitin (Ub) from } \\
\text { an E2 Ub-conjugating } \\
\text { enzyme and transfers Ub to } \\
\text { targeted substrates. Inhibits } \\
\text { TGF- } \beta \text { signalling. } \\
\text { Ubiquitination and } \\
\text { internalization of plasma } \\
\text { membrane channels. } \\
\text { Ubiquitination and } \\
\text { degradation of SGK1 and } \\
\text { TNK2. Ubiquitination of } \\
\text { BRAT1. Dendrite formation } \\
\text { by melanocytes. Regulator of } \\
\text { TOR signalling. } \\
\text { Ubiquitinates and regulates } \\
\text { NTRK1protein levels. }\end{array}$ & \\
\hline
\end{tabular}


Table 5. Cont

\begin{tabular}{|c|c|c|c|c|c|c|c|c|}
\hline $\begin{array}{l}\text { Chromosomal } \\
\text { Locus }^{1}\end{array}$ & Gene $^{2}$ & Gene Name & SLD Domain & $\begin{array}{l}\text { Association with Other } \\
\text { Neurodevelopmental } \\
\text { Disorder(s) }\end{array}$ & $\begin{array}{l}\text { Brain Expression } \\
\text { Status }{ }^{4}\end{array}$ & $\begin{array}{c}\text { Subcellular } \\
\text { Localization }\end{array}$ & $\begin{array}{c}\text { Biological Role } \\
\text { (Protein Function, } \\
\text { Biological Process) }\end{array}$ & Reference $^{5}$ \\
\hline $19 p 13.11$ & NCAN & Neurocan & Dyslexia & & Yes (Enriched) & $\begin{array}{c}\text { Extracellular } \\
\text { (secreted in brain) }\end{array}$ & $\begin{array}{l}\text { A chondroitin sulfate } \\
\text { proteoglycan that binds to } \\
\text { neuronal cell adhesion } \\
\text { molecules and inhibits } \\
\text { neuronal adhesion and } \\
\text { neurite growth (chicken, rat) }\end{array}$ & {$[220,221]$} \\
\hline $21 \mathrm{q} 22.3$ & PCNT & Pericentrin & Dyslexia & - & Yes (Low specificity) & Centrosome & $\begin{array}{l}\text { Interacts with proteins } \\
\text { involved in cilia assembly } \\
\text { Component of filamentous } \\
\text { matrix of the centrosome - } \\
\text { microtubule network } \\
\text { formation (nucleation) via } \\
\text { anchoring } \gamma \text {-tubulin to } \\
\text { centrosome } \\
\text { Preventing premature } \\
\text { centrosome splitting - } \\
\text { inhibiting NEK2 kinase } \\
\text { activity } \\
\text { Interneuron migration }\end{array}$ & {$[222,223]$} \\
\hline $21 \mathrm{q} 22.3$ & $D I P 2 A$ & $\begin{array}{l}\text { Disco interacting } \\
\text { protein } 2 \text { homolog A }\end{array}$ & Dyslexia & ASD & Yes (Low specificity) & $\begin{array}{l}\text { Plasma membrane, } \\
\text { nucleoplasm, } \\
\text { mitochondrion }\end{array}$ & $\begin{array}{l}\text { Acetylation of CTTN - } \\
\text { ensuring correct dendritic } \\
\text { spine morphology and } \\
\text { synaptic transmission } \\
\text { (mouse) }\end{array}$ & \\
\hline $21 \mathrm{q} 22.3$ & S100B & $\begin{array}{l}\text { S100 calcium binding } \\
\text { protein B }\end{array}$ & Dyslexia & & Yes (Enriched) & $\begin{array}{c}\text { Nucleoplasm, } \\
\text { cytosol, extracellular } \\
\text { region }\end{array}$ & $\begin{array}{l}\text { Neurite extension and axonal } \\
\text { proliferation (mouse) } \\
\text { Binds calcium and zinc - } \\
\text { modulates protein } \\
\text { phosphatase } 5 \text { function }\end{array}$ & {$[224,225]$} \\
\hline $21 \mathrm{q} 22.3$ & PRMT2 & $\begin{array}{c}\text { Protein arginine } \\
\text { methyltransferase } 2\end{array}$ & Dyslexia & & Yes (Low specificity) & $\begin{array}{l}\text { Nucleoplasm, } \\
\text { cytosol }\end{array}$ & $\begin{array}{l}\text { Arginine methyltransferase } \\
\text { Inhibits NF-kappa-B } \\
\text { transcription (mouse). } \\
\text { Coactivator for androgen and } \\
\text { estrogen receptors }\end{array}$ & \\
\hline
\end{tabular}


Table 5. Cont

\begin{tabular}{|c|c|c|c|c|c|c|c|c|}
\hline $\begin{array}{l}\text { Chromosomal } \\
\text { Locus }^{1}\end{array}$ & Gene $^{2}$ & Gene Name & SLD Domain & $\begin{array}{l}\text { Association with Other } \\
\text { Neurodevelopmental } \\
\text { Disorder(s) }^{3}\end{array}$ & $\begin{array}{l}\text { Brain Expression } \\
\text { Status }^{4}\end{array}$ & $\begin{array}{l}\text { Subcellular } \\
\text { Localization }^{4}\end{array}$ & $\begin{array}{l}\text { Biological Role } \\
\text { (Protein Function, } \\
\text { Biological Process) }\end{array}$ & Reference $^{5}$ \\
\hline $22 q 12.1$ & MYO18B & Myosin XVIIIB & $\begin{array}{l}\text { Mathematical } \\
\text { abilities }\end{array}$ & & Not detected & $\begin{array}{l}\text { Nucleoplasm \& } \\
\text { centrosome (muscle } \\
\text { cells and } \\
\text { cardiomyocytes) }\end{array}$ & $\begin{array}{l}\text { May regulate muscle-specific } \\
\text { genes (nucleus) and may } \\
\text { influence intracellular } \\
\text { trafficking (cytoplasm) }\end{array}$ & \\
\hline $22 \mathrm{q} 12.3$ & RBFOX2 & $\begin{array}{l}\text { RNA binding fox-1 } \\
\text { homolog } 2\end{array}$ & $\begin{array}{l}\text { Reading and } \\
\text { language } \\
\text { abilities }\end{array}$ & & Yes (Low specificity) & $\begin{array}{l}\text { Nucleoplasm, } \\
\text { cytosol }\end{array}$ & $\begin{array}{c}\text { Regulator of alternative } \\
\text { splicing in neurons - } \\
\text { Cerebellar development and } \\
\text { physiology (mouse) }\end{array}$ & {$[109,226]$} \\
\hline Xq21.31 & PCDH11X & $\begin{array}{l}\text { Protocadherin } 11 \\
\text { X-linked }\end{array}$ & Dyslexia & ASD & Yes (Enriched) & Plasma membrane & $\begin{array}{l}\text { Potential calcium-dependent } \\
\text { cell-adhesion protein } \\
\text { (mouse) }\end{array}$ & \\
\hline
\end{tabular}

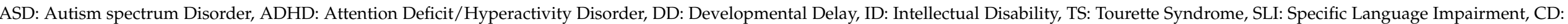

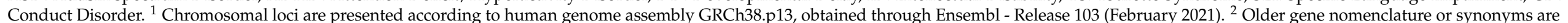

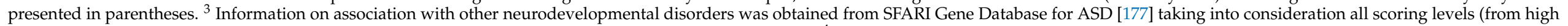

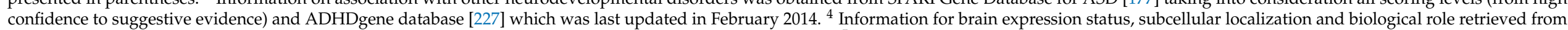
'The Human Protein Atlas' [228], and UniProt [229]. For annotation please refer to 'The Human Protein Atlas'. ${ }^{5}$ Reference provided in addition to information retrieved from 'The Human Protein Atlas'. 

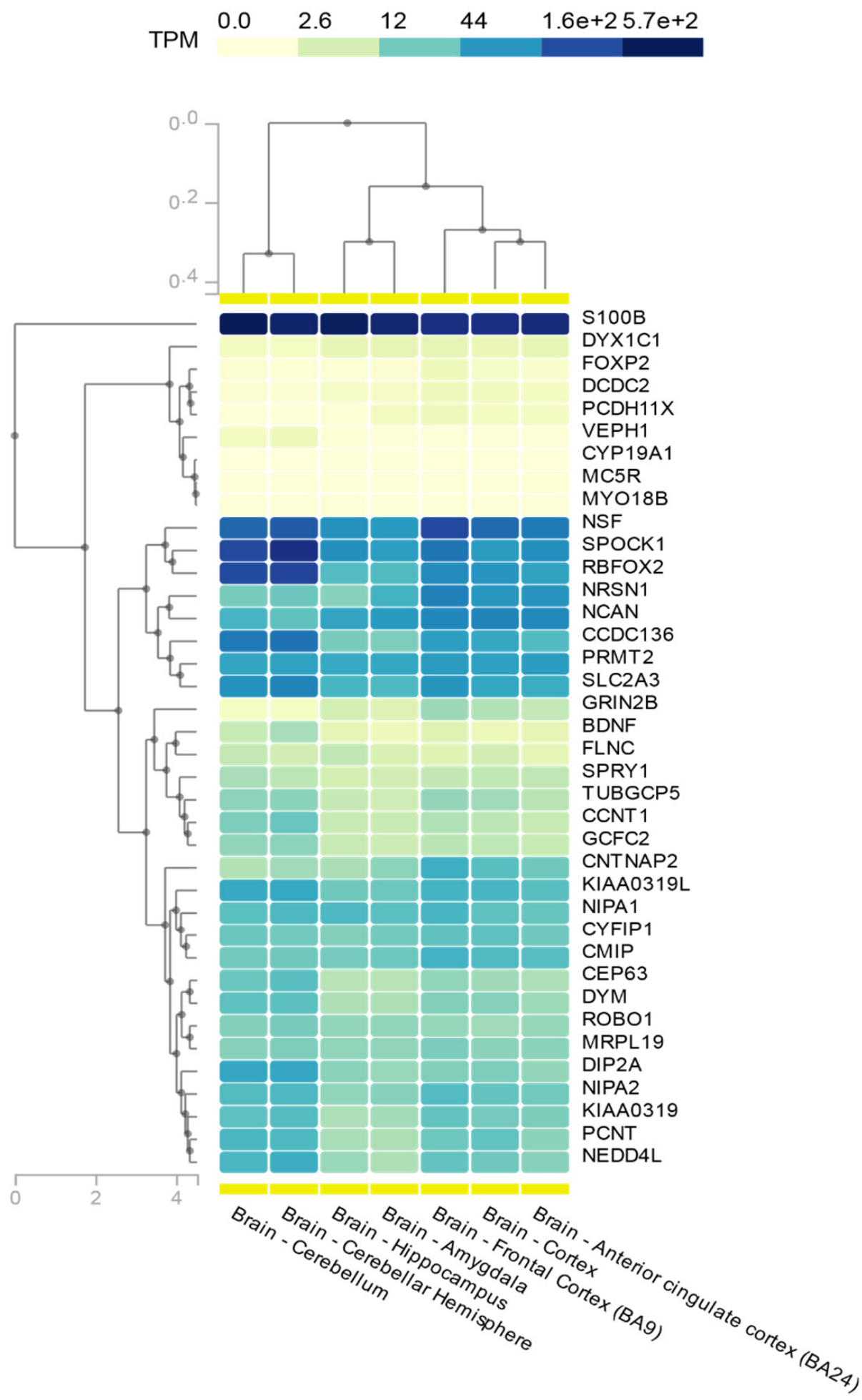

Figure 1. Heatmap of RNA-sequencing-based gene expression from the SLD-associated (proteincoding) genes presented in Table 5, generated in GTEx portal for a multi-gene query in seven brain areas (basal ganglia and hypothalamus are excluded) [204]. SLC2A3 on chromosome 12 was included as an indirectly associated gene (potentially being trans-regulated by a directly associated variant on chromosome 4) (see text in Section 3). PCDHG represents a whole gene cluster, thus excluded from the query. TPM: Transcripts per kilobase million (expresses RNA-sequencing reads normalized for gene length and sequencing depth). 


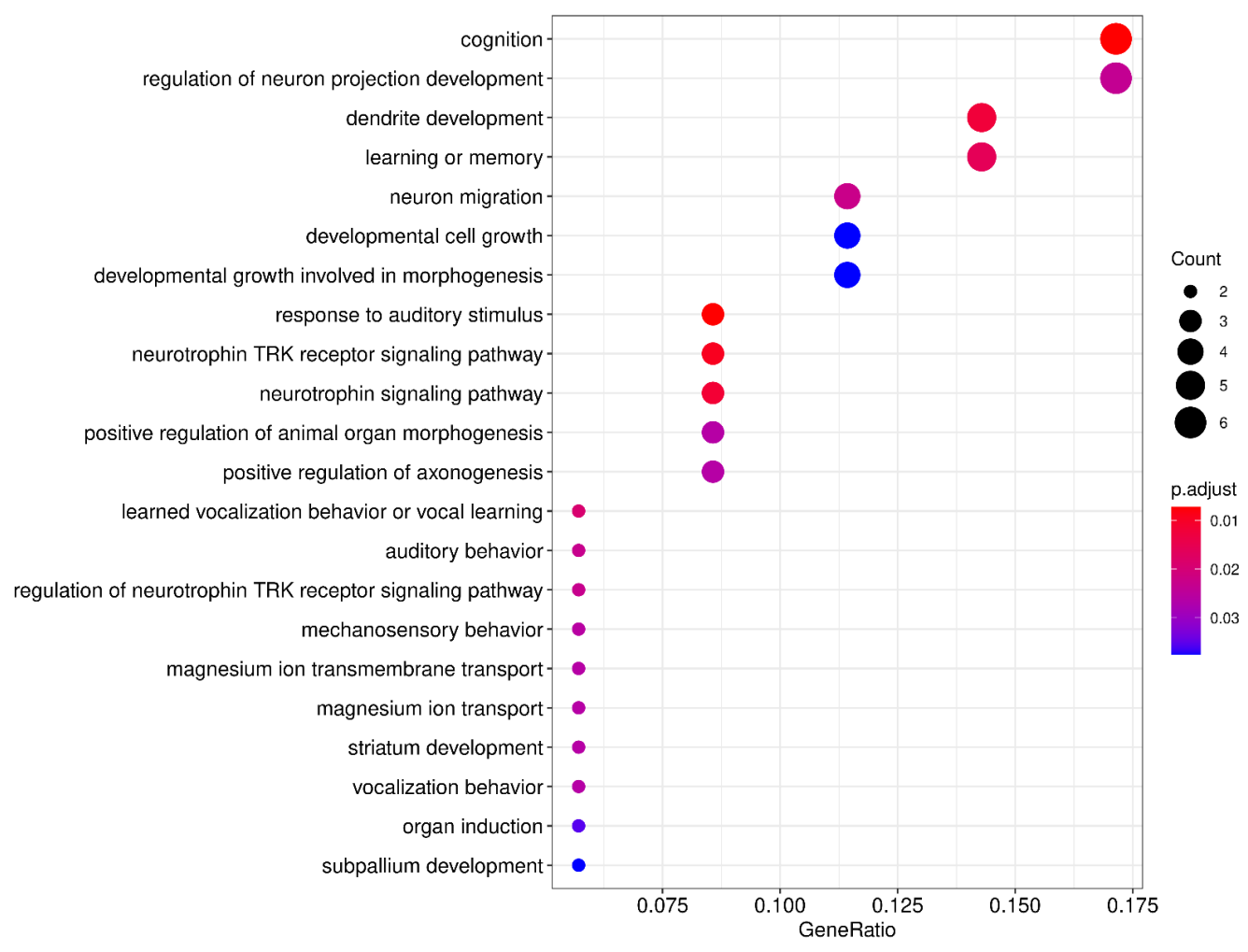

Figure 2. Top gene ontology (GO) terms (Biological Processes; $y$-axis) significantly enriched in the Figure 1. The figure was generated in R using ClusterProfiler. Count: Number of genes per GO term (gene-set), GeneRatio: Number of genes per GO term (gene-set) to the total number of queried genes $(n=36)$, p.adjust: Adjusted $p$-value using the Benjamini-Hochberg correction for multiple comparisons $(p<0.05)$. Data accompanying this figure are available in the Appendix A (Table A1).

\section{Future Research Directions and Open Questions}

It is of interest that increased frequency of sex chromosome aneuploidies (SCA) was reported among SLI and SLD individuals, albeit not statistically significant for the SLD group compared to the general population [230]. Individuals with SLI and SLD do not routinely undergo cytogenetic analysis, so their karyotype remains unknown. On the other hand, it is well-established that individuals with SCAs often show cognitive impairments, including speech and language, learning and mathematical disabilities [231,232]. At this point, it remains unclear whether the underlying biological defect for learning impairment in SCA cases is the deviation from $\mathrm{X}$ or $\mathrm{Y}$ chromosome gene(s) dosage alone, the coinheritance of additional structural variations, such as CNVs [233], specific changes in brain anatomy affecting cognition [234], or a combination of those. Overall, these data highlight the importance of combinatorial evaluation of such neurodevelopmental phenotypes that can benefit from early detection and appropriate management, especially considering the large proportion of cases with SCAs that remain undiagnosed [235].

Another open question is why SLD seems to be more prevalent in males than in females worldwide [236-240], as it is also observed for other neurodevelopmental disorders [241-243]. SLD sex ratios range from about 1.5-3.3:1 in epidemiological samples to 3:1 to 5:1 in referred samples [239]. If this universal sex bias cannot be attributed to factors such as ascertainment bias, definitional or measurement variation, severity of disability, language transparency and alphabet, educational practices or unequal opportunities, race, or socioeconomic status $[1,9,244]$, then what is the remaining underlying causal factor? Arnett et al. suggested that it could be partially explained by cognitive correlates emerging prior to schooling, such as reading ability (slower processing speed in males), which could serve as a proxy for the sex difference in brain development [239]. From the biological perspective, however, convincing genetic evidence to explain the sex bias observed in 
SLD is still lacking or is at least contradictory [15]. In one twin study, males had greater heritability estimates $\left(h^{2}\right)$ than females in word recognition deficit [245], whereas in another the sex-specific $h^{2}$ estimates did not reach statistical significance [246]. In a Chinese cohort of dyslexic children and adolescents analyzed for CNTNAP2, two common variants were found to confer protection against dyslexia in females; one of these variants was marginally associated with the environmental factor of scheduled reading time in female homozygotes showing lower risk for dyslexia [247]. This type of associations will require extensive approaches on genome-wide level, before we begin to speculate which molecular mechanisms underlie sex-specific brain functions. According to the liability threshold model [248], females who meet a diagnostic threshold for ASD or ADHD are expected to carry a higher genetic burden than males and male relatives of females with ASD or ADHD are more likely to be also affected than relatives of affected males [241,249]. To date, although being the subject of great debate, it remains unclear whether hormonal, genetic, epigenetic, cognitive, neurological, anatomical or environmental factors or combinations of the above contribute to sex-biased susceptibility to any of the aforementioned disorders [250], including SLD.

\section{Conclusions}

In the quest for unraveling the genetic architecture of as complex a phenotype as SLD, various methodological approaches have been applied since the first dyslexia-associated genes were identified back in the 1990s (Table 1). In the time that lapsed since, classical linkage studies in unique, large pedigrees-segregating rare, private mutations-chromosomal aberrations, genetic associations, and lately large-scale high-throughput genome-wide genotyping and sequencing studies (Tables 2 and 3) have continued to shape our understanding of this highly complex disorder. The list is continuously populated with novel gene associations whose protein products participate in a variety of biological processes (Table 5). Whether their relevance to SLD manifests via alterations in brain anatomy, connectivity and function (assessed via neuroimaging techniques-Table 4) or via perturbed cellular mechanisms (assessed via functional studies) raises the need for more research in order to reach confidence that these associations hold true. The nature of SLD, unique to our humankind and to properties of the human brain, renders the in vivo experimentation in other species suboptimal. With new technologies and analytical tools, including fourth-generation sequencing and neuroimaging, we will continue to search for the missing heritability with the ultimate hope that at least some genetic findings will translate into predictive and/or preventive measures. To do so, we will need to bridge the knowledge gaps between genomics, molecular pathways, cellular communication, neuronal circuits, neuroimaging data, with human cognition and brain function. This is a long but intriguing path to take for scientists approaching SLD from different scientific disciplines, yet 'intriguing' has always been the driving force.

Author Contributions: Literature search, M.G., I.D. and E.S.; writing—original draft preparation, M.G., I.D., E.S. and E.B.; writing—review and editing, M.G. and E.B.; supervision, M.G. All authors have read and agreed to the published version of the manuscript.

Funding: This research received no external funding.

Institutional Review Board Statement: Not applicable.

Informed Consent Statement: Not applicable.

Data Availability Statement: No new data were created or analyzed in this study. Data sharing is not applicable to this article.

Acknowledgments: We ought to apologize to the plethora of scientists whose studies and painstaking work may have been omitted from the present review; the literature of SLD (particularly dyslexia) is truly vast. We thank PhD candidate Margaritis Tsifintaris for his assistance in preparing Figure 2.

Conflicts of Interest: The authors declare no conflict of interest. 


\section{Appendix A}

Table A1. Original data pertaining to Figure 2.

\begin{tabular}{|c|c|c|c|c|c|c|c|c|}
\hline ID & Description & Gene Ratio & BgRatio & p Value & p.Adjust & q Value & Gene ID & Count \\
\hline GO:0010996 & $\begin{array}{l}\text { response to } \\
\text { auditory } \\
\text { stimulus }\end{array}$ & $3 / 36$ & $26 / 18,670$ & $1.66 \times 10^{-5}$ & 0.0086304564034056 & 0.00703130190039533 & KIAA0319/FOXP2/CNTNAP2 & 3 \\
\hline GO:0050890 & cognition & $6 / 36$ & $296 / 18,670$ & $1.97 \times 10^{-5}$ & 0.0086304564034056 & 0.00703130190039533 & FOXP2/CNTNAP2/BDNF/GRIN2B/CYFIP1/S100B & 6 \\
\hline GO:0048011 & $\begin{array}{c}\text { neurotrophin } \\
\text { TRK receptor } \\
\text { signaling } \\
\text { pathway }\end{array}$ & $3 / 36$ & $33 / 18,670$ & $3.45 \times 10^{-5}$ & 0.0100801981306244 & 0.00821241808767524 & SPRY1/BDNF/CYFIP1 & 3 \\
\hline GO:0016358 & $\begin{array}{c}\text { dendrite } \\
\text { development }\end{array}$ & $5 / 36$ & $233 / 18,670$ & $7.97 \times 10^{-5}$ & 0.0139693179256901 & 0.0113809151088896 & DCDC2/KIAA0319/CYFIP1/NEDD4L/RBFOX2 & 5 \\
\hline GO:0007611 & $\begin{array}{l}\text { learning or } \\
\text { memory }\end{array}$ & $5 / 36$ & $256 / 18,670$ & 0.000124138944672079 & 0.0181242859221235 & 0.0147660007873104 & FOXP2/CNTNAP2/BDNF/GRIN2B/S100B & 5 \\
\hline GO:0098598 & $\begin{array}{c}\text { learned } \\
\text { vocalization } \\
\text { behavior or } \\
\text { vocal learning }\end{array}$ & $2 / 36$ & $10 / 18,670$ & 0.000161100993018104 & 0.020160638554837 & 0.0164250335738759 & FOXP2/CNTNAP2 & 2 \\
\hline GO:0001764 & $\begin{array}{c}\text { neuron } \\
\text { migration }\end{array}$ & $4 / 36$ & $157 / 18,670$ & 0.000229876442023158 & 0.0243726689138727 & 0.0198566084157723 & SPOCK1/DCDC2/KIAA0319/DNAAF4 & 4 \\
\hline GO:0031223 & $\begin{array}{l}\text { auditory } \\
\text { behavior }\end{array}$ & $2 / 36$ & $13 / 18,670$ & 0.000278226814085305 & 0.0243726689138727 & 0.0198566084157723 & FOXP2/CNTNAP2 & 2 \\
\hline GO:0051386 & $\begin{array}{l}\text { regulation of } \\
\text { neurotrophin } \\
\text { TRK receptor } \\
\text { signaling } \\
\text { pathway }\end{array}$ & $2 / 36$ & $13 / 18,670$ & 0.000278226814085305 & 0.0243726689138727 & 0.0198566084157723 & SPRY1/CYFIP1 & 2 \\
\hline GO:0010975 & $\begin{array}{l}\text { regulation of } \\
\text { neuron } \\
\text { projection } \\
\text { development }\end{array}$ & $6 / 36$ & $499 / 18,670$ & 0.000348456394019227 & 0.0272748656682451 & 0.0222210513375032 & ROBO1/SPOCK1/KIAA0319/BDNF/CYFIP1/NEDD4L & 6 \\
\hline
\end{tabular}


Table A1. Cont.

\begin{tabular}{|c|c|c|c|c|c|c|c|c|}
\hline ID & Description & Gene Ratio & BgRatio & $\mathrm{p}$ Value & p.Adjust & q Value & Gene ID & Count \\
\hline GO:0007638 & $\begin{array}{l}\text { mechanosensory } \\
\text { behavior }\end{array}$ & $2 / 36$ & $15 / 18,670$ & 0.000373628296825275 & 0.0272748656682451 & 0.0222210513375032 & FOXP2/CNTNAP2 & 2 \\
\hline GO:1903830 & $\begin{array}{l}\text { magnesium ion } \\
\text { transmembrane } \\
\text { transport }\end{array}$ & $2 / 36$ & $16 / 18,670$ & 0.000426486056377473 & 0.0279522417733895 & 0.0227729150713267 & NIPA1/NIPA2 & 2 \\
\hline GO:0015693 & $\begin{array}{l}\text { magnesium ion } \\
\text { transport }\end{array}$ & $2 / 36$ & $17 / 18,670$ & 0.000482764901757518 & 0.0279522417733895 & 0.0227729150713267 & NIPA1/NIPA2 & 2 \\
\hline GO:0110110 & $\begin{array}{l}\text { positive regulation } \\
\text { of animal organ } \\
\text { morphogenesis }\end{array}$ & $3 / 36$ & $81 / 18,670$ & 0.000506610816906104 & 0.0279522417733895 & 0.0227729150713267 & ROBO1/SPRY1/FOXP2 & 3 \\
\hline GO:0021756 & $\begin{array}{c}\text { striatum } \\
\text { development }\end{array}$ & $2 / 36$ & $18 / 18,670$ & 0.000542452180533815 & 0.0279522417733895 & 0.0227729150713267 & FOXP2/CNTNAP2 & 2 \\
\hline GO:0071625 & $\begin{array}{l}\text { vocalization } \\
\text { behavior }\end{array}$ & $2 / 36$ & $18 / 18,670$ & 0.000542452180533815 & 0.0279522417733895 & 0.0227729150713267 & FOXP2/CNTNAP2 & 2 \\
\hline GO:0050772 & $\begin{array}{l}\text { positive regulation } \\
\text { of axonogenesis }\end{array}$ & $3 / 36$ & $85 / 18,670$ & 0.000583381347572954 & 0.0283912255818838 & 0.0231305586932435 & ROBO1/BDNF/CYFIP1 & 3 \\
\hline GO:0001759 & organ induction & $2 / 36$ & $22 / 18,670$ & 0.000815033760170356 & 0.0375773459952227 & 0.030614564509446 & ROBO1/SPRY1 & 2 \\
\hline GO:0048588 & $\begin{array}{l}\text { developmental cell } \\
\text { growth }\end{array}$ & $4 / 36$ & $234 / 18,670$ & 0.0010340175426981 & 0.0418284073790138 & 0.0340779382395714 & BDNF/CYFIP1/NEDD4L/PRMT2 & 4 \\
\hline GO:0060560 & $\begin{array}{l}\text { developmental } \\
\text { growth involved in } \\
\text { morphogenesis }\end{array}$ & $4 / 36$ & $235 / 18,670$ & 0.00105048511682455 & 0.0418284073790138 & 0.0340779382395714 & SPRY1/BDNF/CYFIP1/NEDD4L & 4 \\
\hline GO:0021987 & $\begin{array}{c}\text { cerebral cortex } \\
\text { development }\end{array}$ & $3 / 36$ & $116 / 18,670$ & 0.00143700209694573 & 0.0547310363880202 & 0.0445898133514512 & ROBO1/FOXP2/CNTNAP2 & 3 \\
\hline
\end{tabular}




\section{References}

1. American Psychiatric Association. Diagnostic and Statistical Manual of Mental Disorders, 4th ed.; American Psychiatric Association: Washington, DC, USA, 2006.

2. Cortiella, C.; Horowitz, S.H. The State of Learning Disabilities: Facts, Trends and Emerging Issues, 3rd ed.; National Center for Learning Disabilities: New York, NY, USA, 2014; pp. 2-5.

3. International Dyslexia Association. DSM-Changes in Diagnostic Criteria for Specific Learning Disabilities (SLD)1: What Are the Implications? Available online: https:/ / dyslexiaida.org/dsm5-update/ (accessed on 2 April 2021).

4. National Joint Committee on Learning Disabilities_Definition of Learning Disabilities. Available online: https://njcld.files. wordpress.com/2018/10/1d-definition.pdf (accessed on 2 April 2021).

5. Kucian, K.; Von Aster, M. Developmental dyscalculia. Eur. J. Nucl. Med. Mol. Imaging 2014, 174, 1-13. [CrossRef]

6. Peters, L.; Ansari, D. Are specific learning disorders truly specific, and are they disorders? Trends Neurosci. Educ. 2019, 17, 100115. [CrossRef]

7. Wagner, R.K.; Zirps, F.A.; Edwards, A.A.; Wood, S.G.; Joyner, R.E.; Becker, B.J.; Liu, G.; Beal, B. The Prevalence of Dyslexia: A New Approach to Its Estimation. J. Learn. Disabil. 2020, 53, 354-365. [CrossRef] [PubMed]

8. Katusic, S.K.; Colligan, R.C.; Barbaresi, W.J.; Schaid, D.J.; Jacobsen, S.J. Incidence of Reading Disability in a Population-Based Birth Cohort, 1976-1982, Rochester, Minn. Mayo Clin. Proc. 2001, 76, 1081-1092. [CrossRef] [PubMed]

9. De Kovel, C.G.F.; Hol, F.A.; Heister, J.G.A.M.; Willemen, J.J.H.T.; Sandkuijl, L.A.; Franke, B.; Padberg, G.W. Genomewide scan identifies susceptibility locus for dyslexia on Xq27 in an extended Dutch family. J. Med. Genet. 2004, 41, 652-657. [CrossRef] [PubMed]

10. Lin, Y.; Zhang, X.; Huang, Q.; Lv, L.; Huang, A.; Li, A.; Wu, K.; Huang, Y. The Prevalence of Dyslexia in Primary School Children and Their Chinese Literacy Assessment in Shantou, China. Int. J. Environ. Res. Public Health 2020, 17, 7140. [CrossRef]

11. Peterson, R.L.; Pennington, B.F. Developmental Dyslexia. Annu. Rev. Clin. Psychol. 2015, 11, 283-307. [CrossRef]

12. Bonti, E.; Giannoglou, S.; Georgitsi, M.; Sofologi, M.; Porfyri, G.-N.; Mousioni, A.; Konsta, A.; Tatsiopoulou, P.; Kamari, A.; Vavetsi, S.; et al. Clinical Profiles and Socio-Demographic Characteristics of Adults with Specific Learning Disorder in Northern Greece. Brain Sci. 2021, 11, 602. [CrossRef]

13. Habib, M. The neurological basis of developmental dyslexia: An overview and working hypothesis. Brain 2000, 123, 2373-2399. [CrossRef]

14. Protopapas, A.; Parrila, R. Is Dyslexia a Brain Disorder? Brain Sci. 2018, 8, 61. [CrossRef]

15. Ramus, F.; Altarelli, I.; Jednoróg, K.; Zhao, J.; di Covella, L.S. Neuroanatomy of developmental dyslexia: Pitfalls and promise. Neurosci. Biobehav. Rev. 2018, 84, 434-452. [CrossRef] [PubMed]

16. Gerber, P.J. The Impact of Learning Disabilities on Adulthood. J. Learn. Disabil. 2011, 45, 31-46. [CrossRef] [PubMed]

17. Joyner, R.E.; Wagner, R.K. Co-Occurrence of Reading Disabilities and Math Disabilities: A Meta-Analysis. Sci. Stud. Read. 2020, 24, 14-22. [CrossRef] [PubMed]

18. Landerl, K.; Moll, K. Comorbidity of learning disorders: Prevalence and familial transmission. J. Child. Psychol. Psychiatry 2010, 51, 287-294. [CrossRef] [PubMed]

19. Berninger, V.W.; Raskind, W.; Richards, T.; Abbott, R.; Stock, P.A. Multidisciplinary Approach to Understanding Developmental Dyslexia within Working-Memory Architecture: Genotypes, Phenotypes, Brain, and Instruction. Dev. Neuropsychol. 2008, 33, 707-744. [CrossRef] [PubMed]

20. Bonti, E.; Bampalou, C.E.; Kouimtzi, E.M.; Kyritsis, Z. Greek Young Adults with Specific Learning Disabilities Seeking Learning Assessments. Learn. Disabil. Q. 2018, 41, 119-126. [CrossRef]

21. Bampalou, C.E.; Kouimtzi, E.M.; Bonti, E.; Kyritsis, Z. Greek Adult Population with Specific Learning Disabilities: Epidemiology, Demographics And Gender Differences. Hell J. Psychol. 2020, 17, 97-118.

22. DeFries, J.C.; Fulker, D.W.; Labuda, M.C. Evidence for a genetic aetiology in reading disability of twins. Nat. Cell Biol. 1987, 329, 537-539. [CrossRef]

23. Alarcón, M.; DeFries, J.C.; Light, J.G.; Pennington, B.F. A Twin Study of Mathematics Disability. J. Learn. Disabil. 1997, 30, 617-623. [CrossRef]

24. Plomin, R.; Kovas, Y. Generalist Genes and Learning Disabilities. Psychol. Bull. 2005, 131, 592-617. [CrossRef]

25. Willcutt, E.G.; McGrath, L.M.; Pennington, B.F.; Keenan, J.M.; DeFries, J.C.; Olson, R.K.; Wadsworth, S.J. Understanding Comorbidity between Specific Learning Disabilities. New Dir. Child. Adolesc. Dev. 2019, 2019, 91-109. [CrossRef]

26. Francks, C.; Fisher, S.E.; Olson, R.K.; Pennington, B.F.; Smith, S.D.; DeFries, J.C.; Monaco, A.P. Fine mapping of the chromosome 2p12-16 dyslexia susceptibility locus: Quantitative association analysis and positional candidate genes SEMA4F and OTX. Psychiatr. Genet. 2002, 12, 35-41. [CrossRef]

27. Gialluisi, A.; Andlauer, T.F.M.; Mirza-Schreiber, N.; Moll, K.; Becker, J.; Hoffmann, P.; Ludwig, K.U.; Czamara, D.; Pourcain, B.S.; Honbolygó, F.; et al. Genome-wide association study reveals new insights into the heritability and genetic correlates of developmental dyslexia. Mol. Psychiatry 2020. [CrossRef] [PubMed]

28. Shalev, R.S.; Manor, O.; Ayali, M.; Badichi, N.; Gross-Tsur, V.; Kerem, B.; Friedlander, Y. Developmental Dyscalculia Is a Familial Learning Disability. J. Learn. Disabil. 2001, 34, 59-65. [CrossRef] 
29. Schumacher, J.; Hoffmann, P.; Schmäl, C.; Schulte-Körne, G.; Nöthen, M.M. Genetics of dyslexia: The evolving landscape. J. Med. Genet. 2007, 44, 289-297. [CrossRef] [PubMed]

30. Snowling, M.J.; Muter, V.; Carroll, J. Children at family risk of dyslexia: A follow-up in early adolescence. J. Child Psychol. Psychiatry 2007, 48, 609-618. [CrossRef] [PubMed]

31. Giménez, A.; Ortiz, A.; López-Zamora, M.; Sánchez, A.; Luque, J.L. Parents' reading history as an indicator of risk for reading difficulties. Ann. Dyslexia 2017, 67, 259-280. [CrossRef] [PubMed]

32. Smith, S.; Kimberling, W.; Pennington, B.; Lubs, H. Specific reading disability: Identification of an inherited form through linkage analysis. Science 1983, 219, 1345-1347. [CrossRef] [PubMed]

33. Pennington, B.F.; Gilger, J.W.; Pauls, D.; Smith, S.A.; Smith, S.D.; DeFries, J.C. Evidence for Major Gene Transmission of Developmental Dyslexia. JAMA 1991, 266, 1527-1534. [CrossRef]

34. OMIM-Online Mendelian Inheritance in Man. Available online: https://www.omim.org/ (accessed on 2 April 2021).

35. Scerri, T.S.; Schulte-Korne, T.S.S. Genetics of developmental dyslexia. Eur. Child. Adolesc. Psychiatry 2009, 19, 179-197. [CrossRef] [PubMed]

36. Poelmans, G.; Buitelaar, J.K.; Pauls, D.L.; Franke, B. A theoretical molecular network for dyslexia: Integrating available genetic findings. Mol. Psychiatry 2010, 16, 365-382. [CrossRef]

37. Kere, J. The molecular genetics and neurobiology of developmental dyslexia as model of a complex phenotype. Biochem. Biophys. Res. Commun. 2014, 452, 236-243. [CrossRef] [PubMed]

38. Mascheretti, S.; De Luca, A.; Trezzi, V.; Peruzzo, D.; Nordio, A.; Marino, C.; Arrigoni, F. Neurogenetics of developmental dyslexia: From genes to behavior through brain neuroimaging and cognitive and sensorial mechanisms. Transl. Psychiatry 2017, 7, e987. [CrossRef]

39. Müller, B.; The LEGASCREEN Consortium; Wilcke, A.; Czepezauer, I.; Ahnert, P.; Boltze, J.; Kirsten, H. Association, characterisation and meta-analysis of SNPs linked to general reading ability in a German dyslexia case-control cohort. Sci. Rep. 2016, 6, 27901. [CrossRef] [PubMed]

40. De Kovel, C.G.; Franke, B.; Hol, F.A.; Lebrec, J.J.; Maassen, B.; Brunner, H.; Padberg, G.W.; Platko, J.; Pauls, D. Confirmation of dyslexia susceptibility loci on chromosomes $1 \mathrm{p}$ and $2 \mathrm{p}$, but not $6 \mathrm{p}$ in a Dutch sib-pair collection. Am. J. Med. Genet. Part. B Neuropsychiatr. Genet. 2008, 147, 294-300. [CrossRef] [PubMed]

41. Kovas, Y.; Plomin, R. Learning Abilities and Disabilities. Curr. Dir. Psychol. Sci. 2007, 16, 284-288. [CrossRef] [PubMed]

42. Davis, O.S.P.; The Wellcome Trust Case Control Consortium; Band, G.; Pirinen, M.; Haworth, C.M.A.; Meaburn, E.L.; Kovas, Y.; Harlaar, N.; Docherty, S.J.; Hanscombe, K.B.; et al. The correlation between reading and mathematics ability at age twelve has a substantial genetic component. Nat. Commun. 2014, 5, 4204. [CrossRef]

43. Stefansson, H.; Meyer-Lindenberg, A.; Steinberg, S.; Magnusdottir, B.B.; Morgen, K.; Arnarsdottir, S.; Bjornsdottir, G.; Walters, G.B.; Jonsdottir, G.A.; Doyle, O.M.; et al. CNVs conferring risk of autism or schizophrenia affect cognition in controls. Nat. Cell Biol. 2014, 505, 361-366. [CrossRef]

44. Ulfarsson, M.O.; Walters, G.B.; Gustafsson, O.; Steinberg, S.; Silva, A.; Doyle, O.M.; Brammer, M.; Gudbjartsson, D.F.; Arnarsdottir, S.; Jonsdottir, G.A.; et al. 15q11.2 CNV affects cognitive, structural and functional correlates of dyslexia and dyscalculia. Transl. Psychiatry 2017, 7, e1109. [CrossRef]

45. Grigorenko, E.L.; Wood, F.B.; Meyer, M.S.; Hart, L.A.; Speed, W.C.; Shuster, A.; Pauls, D.L. Susceptibility loci for distinct components of developmental dyslexia on chromosomes 6 and 15. Am. J. Hum. Genet. 1997, 60, 27-39.

46. Taipale, M.; Kaminen, N.; Nopola-Hemmi, J.; Haltia, T.; Myllyluoma, B.; Lyytinen, H.; Muller, K.; Kaaranen, M.; Lindsberg, P.J.; Hannula-Jouppi, K.; et al. A candidate gene for developmental dyslexia encodes a nuclear tetratricopeptide repeat domain protein dynamically regulated in brain. Proc. Natl. Acad. Sci. USA 2003, 100, 11553-11558. [CrossRef] [PubMed]

47. Deffenbacher, K.E.; Kenyon, J.B.; Hoover, D.M.; Olson, R.K.; Pennington, B.F.; DeFries, J.C.; Smith, S.D. Refinement of the 6p21.3 quantitative trait locus influencing dyslexia: Linkage and association analyses. Qual. Life Res. 2004, 115, 128-138. [CrossRef] [PubMed]

48. Francks, C.; Paracchini, S.; Smith, S.D.; Richardson, A.J.; Scerri, T.S.; Cardon, L.R.; Marlow, A.J.; MacPhie, I.L.; Walter, J.; Pennington, B.F.; et al. A 77-Kilobase Region of Chromosome 6p22.2 Is Associated with Dyslexia in Families from the United Kingdom and from the United States. Am. J. Hum. Genet. 2004, 75, 1046-1058. [CrossRef]

49. Cope, N.; Harold, D.; Hill, G.; Moskvina, V.; Stevenson, J.; Holmans, P.; Owen, M.J.; O’Donovan, M.C.; Williams, J. Strong Evidence That KIAA0319 on Chromosome 6p Is a Susceptibility Gene for Developmental Dyslexia. Am. J. Hum. Genet. 2005, 76, 581-591. [CrossRef] [PubMed]

50. Schumacher, J.; Anthoni, H.; Dahdouh, F.; König, I.R.; Hillmer, A.M.; Kluck, N.; Manthey, M.; Plume, E.; Warnke, A.; Remschmidt, H.; et al. Strong Genetic Evidence of DCDC2 as a Susceptibility Gene for Dyslexia. Am. J. Hum. Genet. 2006, 78, 52-62. [CrossRef] [PubMed]

51. König, I.R.; Schumacher, J.; Hoffmann, P.; Kleensang, A.; Ludwig, K.U.; Grimm, T.; Neuhoff, N.; Preis, M.; Roeske, D.; Warnke, A.; et al. Mapping for dyslexia and related cognitive trait loci provides strong evidence for further risk genes on chromosome $6 \mathrm{p} 21$. Am. J. Med. Genet. Part. B Neuropsychiatr. Genet. 2010, 156, 36-43. [CrossRef]

52. Fagerheim, T.; Raeymaekers, P.; Tønnessen, F.E.; Pedersen, M.; Tranebjærg, L.; Lubs, H.A. A New Gene (DYX3) for Dyslexia Is Located on Chromosome. J. Med. Genet. 1999, 36, 664-669. [CrossRef] 
53. Anthoni, H.; Zucchelli, M.; Matsson, H.; Müller-Myhsok, B.; Fransson, I.; Schumacher, J.; Massinen, S.; Onkamo, P.; Warnke, A.; Griesemann, H.; et al. A locus on 2p12 containing the co-regulated MRPL19 and C2ORF3 genes is associated to dyslexia. Hum. Mol. Genet. 2007, 16, 667-677. [CrossRef]

54. Petryshen, T.L.; Kaplan, B.J.; Liu, M.F.; De French, N.S.; Tobias, R.; Hughes, M.L.; Field, L.L. Evidence for a susceptibility locus on chromosome 6q influencing phonological coding dyslexia. Am. J. Med. Genet. 2001, 105, 507-517. [CrossRef]

55. Nopola-Hemmi, J.; Myllyluoma, B.; Haltia, T.; Taipale, M.; Ollikainen, V.; Ahonen, T.; Voutilainen, A.; Kere, J.; Widén, E. A dominant gene for developmental dyslexia on chromosome. J. Med. Genet. 2001, 38, 658-664. [CrossRef]

56. Hannula-Jouppi, K.; Kaminen-Ahola, N.; Taipale, M.; Eklund, R.; Nopola-Hemmi, J.; Kääriäinen, H.; Kere, J. The Axon Guidance Receptor Gene ROBO1 Is a Candidate Gene for Developmental Dyslexia. PLoS Genet. 2005, 1, e50. [CrossRef]

57. Fisher, S.E.; Francks, C.; Marlow, A.J.; MacPhie, I.L.; Newbury, D.F.; Cardon, L.R.; Ishikawa-Brush, Y.; Richardson, A.J.; Talcott, J.B.; Gayán, J.; et al. Independent genome-wide scans identify a chromosome 18 quantitative-trait locus influencing dyslexia. Nat. Genet. 2001, 30, 86-91. [CrossRef] [PubMed]

58. Scerri, T.S.; Paracchini, S.; Morris, A.; MacPhie, I.L.; Talcott, J.; Stein, J.; Smith, S.D.; Pennington, B.F.; Olson, R.K.; DeFries, J.C.; et al. Identification of Candidate Genes for Dyslexia Susceptibility on Chromosome. PLoS ONE 2010, 5, e13712. [CrossRef]

59. Hsiung, G.-Y.R.; Kaplan, B.J.; Petryshen, T.L.; Lu, S.; Field, L.L. A dyslexia susceptibility locus (DYX7) linked to dopamine D4 receptor (DRD4) region on chromosome 11p15. Am. J. Med. Genet. 2004, 125B, 112-119. [CrossRef] [PubMed]

60. Froster, U.; Schulte-Korne, G.; Hebebrand, J.; Remschmidt, H. Cosegregation of balanced translocation $(1 ; 2)$ with retarded speech development and dyslexia. Lancet 1993, 342, 178-179. [CrossRef]

61. Rabin, M.; Wen, X.; Hepburn, M.; Lubs, H.; Feldman, E.; Duara, R. Suggestive linkage of developmental dyslexia to chromosome 1p34-p. Lancet 1993, 342, 178. [CrossRef]

62. Grigorenko, E.L.; Wood, F.B.; Meyer, M.S.; Pauls, J.E.D.; Hart, L.A.; Pauls, D.L. Linkage Studies Suggest a Possible Locus for Developmental Dyslexia on Chromosome 1p. Am. J. Med. Genet. 2001, 105, 120-129. [CrossRef]

63. Tzenova, J.; Kaplan, B.J.; Petryshen, T.L.; Field, L.L. Confirmation of a dyslexia susceptibility locus on chromosome 1p34-p36 in a set of 100 Canadian families. Am. J. Med. Genet. 2004, 127B, 117-124. [CrossRef]

64. Huc-Chabrolle, M.; Charon, C.; Guilmatre, A.; Vourc'H, P.; Tripi, G.; Barthez, M.A.; Sizaret, E.; Thepault, R.A.; Le Gallic, S.; Hager, J.; et al. Xq27 FRAXA Locus is a Strong Candidate for Dyslexia: Evidence from a Genome-Wide Scan in French Families. Behav. Genet. 2013, 43, 132-140. [CrossRef]

65. Poelmans, G.; Engelen, J.J.M.; Van Lent-Albrechts, J.; Smeets, H.J.; Schoenmakers, E.; Franke, B.; Buitelaar, J.K.; Wuisman-Frerker, M.; Erens, W.; Steyaert, J.; et al. Identification of novel dyslexia candidate genes through the analysis of a chromosomal deletion. Am. J. Med. Genet. Part B Neuropsychiatr. Genet. 2008, 150B, 140-147. [CrossRef]

66. Anthoni, H.; Sucheston, L.E.; Lewis, B.A.; Tapia-Páez, I.; Fan, X.; Zucchelli, M.; Taipale, M.; Stein, C.; Hokkanen, M.-E.; Castrén, E.; et al. The Aromatase Gene CYP19A1: Several Genetic and Functional Lines of Evidence Supporting a Role in Reading, Speech and Language. Behav. Genet. 2012, 42, 509-527. [CrossRef] [PubMed]

67. Field, L.L.; Shumansky, K.; Ryan, J.; Truong, D.; Swiergala, E.; Kaplan, B.J. Dense-map genome scan for dyslexia supports loci at 4q13, 16p12, 17q22; suggests novel locus at 7q. Genes Brain Behav. 2012, 12, 56-69. [CrossRef] [PubMed]

68. Docherty, S.J.; Davis, O.S.P.; Kovas, Y.; Meaburn, E.L.; Dale, P.S.; Petrill, S.A.; Schalkwyk, L.C.; Plomin, R. A genome-wide association study identifies multiple loci associated with mathematics ability and disability. Genes Brain Behav. 2010, 9, 234-247. [CrossRef] [PubMed]

69. Einarsdottir, E.; Peyrard-Janvid, M.; Darki, F.; Tuulari, J.J.; Merisaari, H.; Karlsson, L.; Scheinin, N.M.; Saunavaara, J.; Parkkola, R.; Kantojärvi, K.; et al. Identification of NCAN as a candidate gene for developmental dyslexia. Sci. Rep. 2017, 7, 1-11. [CrossRef] [PubMed]

70. Naskar, T.; Faruq, M.; Banerjee, P.; Khan, M.; Midha, R.; Kumari, R.; Devasenapathy, S.; Prajapati, B.; Sengupta, S.; Jain, D.; et al. Ancestral Variations of the PCDHG Gene Cluster Predispose to Dyslexia in a Multiplex Family. EBioMedicine 2018, 28, 168-179. [CrossRef] [PubMed]

71. Grimm, T.; Garshasbi, M.; Puettmann, L.; Chen, W.; Ullmann, R.; Müller-Myhsok, B.; Klopocki, E.; Herbst, L.; Haug, J.; Jensen, L.R.; et al. A Novel Locus and Candidate Gene for Familial Developmental Dyslexia on Chromosome 4q. Zeitschrift Kinder Jugendpsychiatr. Psychother. 2020, 48, 478-489. [CrossRef]

72. Becker, J.; Czamara, D.; Scerri, T.S.; Ramus, F.; Csépe, V.; Talcott, J.B.; Stein, J.; Morris, A.; Ludwig, K.U.; Hoffmann, P.; et al. Genetic analysis of dyslexia candidate genes in the European cross-linguistic NeuroDys cohort. Eur. J. Hum. Genet. 2013, 22, 675-680. [CrossRef]

73. Sánchez-Morán, M.; Hernández, J.A.; Duñabeitia, J.A.; Estévez, A.; Bárcena, L.; González-Lahera, A.; Bajo, M.T.; Fuentes, L.J.; Aransay, A.M.; Carreiras, M. Genetic association study of dyslexia and ADHD candidate genes in a Spanish cohort: Implications of comorbid samples. PLoS ONE 2018, 13, e0206431. [CrossRef]

74. Powers, N.R.; Eicher, J.D.; Butter, F.; Kong, Y.; Miller, L.L.; Ring, S.M.; Mann, M.; Gruen, J.R. Alleles of a Polymorphic ETV6 Binding Site in DCDC2 Confer Risk of Reading and Language Impairment. Am. J. Hum. Genet. 2013, 93, 19-28. [CrossRef]

75. Doust, C.; Gordon, S.D.; Garden, N.; Fisher, S.E.; Martin, N.G.; Bates, T.C.; Luciano, M. The Association of Dyslexia and Developmental Speech and Language Disorder Candidate Genes with Reading and Language Abilities in Adults. Twin Res. Hum. Genet. 2020, 23, 23-32. [CrossRef] 
76. Wigg, K.G.; Couto, J.M.; Feng, Y.; Anderson, B.; Cate-Carter, T.D.; Macciardi, F.; Tannock, R.; Lovett, M.W.; Humphries, T.W.; Barr, C.L. Support for EKN1 as the susceptibility locus for dyslexia on 15q. Mol. Psychiatry 2004, 9, 1111-1121. [CrossRef] [PubMed]

77. Scerri, T.S.; Fisher, S.E.; Francks, C.; MacPhie, I.L.; Paracchini, S.; Richardson, A.J.; Stein, J.F.; Monaco, A.P. Putative functional alleles of DYX1C1 are not associated with dyslexia susceptibility in a large sample of sibling pairs from the UK. J. Med. Genet. 2004, 41, 853-857. [CrossRef] [PubMed]

78. Brkanac, Z.; Chapman, N.H.; Matsushita, M.M.; Chun, L.; Nielsen, K.; Cochrane, E.; Berninger, V.W.; Wijsman, E.M.; Raskind, W.H. Evaluation of candidate genes forDYX1 andDYX2 in families with dyslexia. Am. J. Med. Genet. Part. B Neuropsychiatr. Genet. 2007, 144B, 556-560. [CrossRef] [PubMed]

79. Marino, C.; Citterio, A.; Giorda, R.; Facoetti, A.; Menozzi, G.; Vanzin, L.; Lorusso, M.L.; Nobile, M.; Molteni, M. Association of short-term memory with a variant within DYX1C1 in developmental dyslexia. Genes Brain Behav. 2007, 6, 640-646. [CrossRef] [PubMed]

80. Dahdouh, F.; Anthoni, H.; Tapia-Páez, I.; Peyrard-Janvid, M.; Schulte-Körne, G.; Warnke, A.; Remschmidt, H.; Ziegler, A.; Kere, J.; Müller-Myhsok, B.; et al. Further evidence for DYX1C1 as a susceptibility factor for dyslexia. Psychiatr. Genet. 2009, 19, 59-63. [CrossRef] [PubMed]

81. Bates, T.C.; Lind, P.A.; Luciano, M.; Montgomery, G.W.; Martin, N.; Wright, M.J. Dyslexia and DYX1C1: Deficits in reading and spelling associated with a missense mutation. Mol. Psychiatry 2009, 15, 1190-1196. [CrossRef] [PubMed]

82. Meng, H.; Smith, S.D.; Hager, K.; Held, M.; Liu, J.; Olson, R.K.; Pennington, B.F.; DeFries, J.C.; Gelernter, J.; O’Reilly-Pol, T.; et al. From The Cover: DCDC2 is associated with reading disability and modulates neuronal development in the brain. Proc. Natl. Acad. Sci. USA 2005, 102, 17053-17058. [CrossRef]

83. Ludwig, K.U.; Schumacher, J.; Schulte-Körne, G.; König, I.R.; Warnke, A.; Plume, E.; Anthoni, H.; Peyrard-Janvid, M.; Meng, H.; Ziegler, A.; et al. Investigation of the DCDC2 intron 2 deletion/compound short tandem repeat polymorphism in a large German dyslexia sample. Psychiatr. Genet. 2008, 18, 310-312. [CrossRef]

84. Wilcke, A.; Weissfuss, J.; Kirsten, H.; Wolfram, G.; Boltze, J.; Ahnert, P. The role of gene DCDC2 in German dyslexics. Ann. Dyslexia 2009, 59, 1-11. [CrossRef]

85. Lind, P.A.; Luciano, M.; Wright, M.J.; Montgomery, G.W.; Martin, N.; Bates, T.C. Dyslexia and DCDC2: Normal variation in reading and spelling is associated with DCDC2 polymorphisms in an Australian population sample. Eur. J. Hum. Genet. 2010, 18, 668-673. [CrossRef]

86. Scerri, T.S.; Morris, A.P.; Buckingham, L.-L.; Newbury, D.F.; Miller, L.L.; Monaco, A.P.; Bishop, D.; Paracchini, S. DCDC2, KIAA0319 and CMIP Are Associated with Reading-Related Traits. Biol. Psychiatry 2011, 70, 237-245. [CrossRef]

87. Marino, C.; Mascheretti, S.; Riva, V.; Cattaneo, F.; Rigoletto, C.; Rusconi, M.; Gruen, J.R.; Giorda, R.; Lazazzera, C.; Molteni, M. Pleiotropic Effects of DCDC2 and DYX1C1 Genes on Language and Mathematics Traits in Nuclear Families of Developmental Dyslexia. Behav. Genet. 2010, 41, 67-76. [CrossRef] [PubMed]

88. Marino, C.; Meng, H.; Mascheretti, S.; Rusconi, M.; Cope, N.; Giorda, R.; Molteni, M.; Gruen, J.R. DCDC2 genetic variants and susceptibility to developmental dyslexia. Psychiatr. Genet. 2012, 22, 25-30. [CrossRef] [PubMed]

89. Zuo, P.-X.; Chen, Y.; Zhao, H.; Zhang, Y.-X. DCDC2 gene polymorphisms are associated with developmental dyslexia in Chinese Uyghur children. Neural Regen. Res. 2017, 12, 259-266. [CrossRef] [PubMed]

90. Harold, D.; Paracchini, S.; Scerri, T.; Dennis, M.; Cope, N.; Hill, G.; Moskvina, V.; Walter, J.; Richardson, A.J.; Owen, M.J.; et al. Further evidence that the KIAA0319 gene confers susceptibility to developmental dyslexia. Mol. Psychiatry 2006, 11, 1085-1091. [CrossRef]

91. Paracchini, S.; Steer, C.D.; Buckingham, L.-L.; Morris, A.P.; Ring, S.; Scerri, T.; Stein, J.; Pembrey, M.E.; Ragoussis, J.; Golding, J.; et al. Association of theKIAA0319Dyslexia Susceptibility Gene with Reading Skills in the General Population. Am. J. Psychiatry 2008, 165, 1576-1584. [CrossRef] [PubMed]

92. Dennis, M.Y.; Paracchini, S.; Scerri, T.S.; Prokunina-Olsson, L.; Knight, J.C.; Wade-Martins, R.; Coggill, P.; Beck, S.; Green, E.D.; Monaco, A.P. A Common Variant Associated with Dyslexia Reduces Expression of the KIAA0319 Gene. PLoS Genet. 2009, 5, e1000436. [CrossRef]

93. Couto, J.M.; Livne-Bar, I.; Huang, K.; Xu, Z.; Cate-Carter, T.; Feng, Y.; Wigg, K.; Humphries, T.; Tannock, R.; Kerr, E.N.; et al. Association of Reading Disabilities with Regions Marked by Acetylated H3 Histones in KIAA. Am. J. Med. Genet. Part. B Neuropsychiatr. Genet. 2009, 153B, 447-462. [CrossRef]

94. Mascheretti, S.; Riva, V.; Giorda, R.; Beri, S.; Lanzoni, L.F.E.; Cellino, M.R.; Marino, C. KIAA0319 and ROBO1: Evidence on association with reading and pleiotropic effects on language and mathematics abilities in developmental dyslexia. J. Hum. Genet. 2014, 59, 189-197. [CrossRef]

95. Couto, J.M.; Gomez, L.; Wigg, K.; Cate-Carter, T.; Archibald, J.; Anderson, B.; Tannock, R.; Kerr, E.N.; Lovett, M.W.; Humphries, T.; et al. The KIAA0319-Like (KIAA0319L) Gene on Chromosome 1p34 as a Candidate for Reading Disabilities. J. Neurogenetics 2008, 22, 295-313. [CrossRef]

96. Peter, B.; Raskind, W.H.; Matsushita, M.; Lisowski, M.; Vu, T.; Berninger, V.W.; Wijsman, E.M.; Brkanac, Z. Replication of CNTNAP2 association with nonword repetition and support for FOXP2 association with timed reading and motor activities in a dyslexia family sample. J. Neurodev. Disord. 2010, 3, 39-49. [CrossRef] 
97. Roeske, D.; Ludwig, K.U.; Neuhoff, N.; Becker, J.; Bartling, J.; Bruder, J.; Brockschmidt, F.F.; Warnke, A.; Remschmidt, H.; Hoffmann, P.; et al. First genome-wide association scan on neurophysiological endophenotypes points to trans-regulation effects on SLC2A3 in dyslexic children. Mol. Psychiatry 2009, 16, 97-107. [CrossRef]

98. Mascheretti, S.; Facoetti, A.; Giorda, R.; Beri, S.; Riva, V.; Trezzi, V.; Cellino, M.R.; Marino, C. GRIN2B mediates susceptibility to intelligence quotient and cognitive impairments in developmental dyslexia. Psychiatr. Genet. 2015, 25, 9-20. [CrossRef] [PubMed]

99. Jasińska, K.K.; Molfese, P.J.; Kornilov, S.A.; Mencl, W.E.; Frost, S.J.; Lee, M.; Pugh, K.R.; Grigorenko, E.L.; Landi, N. The BDNF Val66Met Polymorphism Influences Reading Ability and Patterns of Neural Activation in Children. PLoS ONE 2016, 11, e0157449. [CrossRef]

100. Mascheretti, S.; Perdue, M.V.; Feng, B.; Andreola, C.; Dionne, G.; Jasińska, K.K.; Pugh, K.R.; Grigorenko, E.L.; Landi, N. From BDNF to Reading: Neural Activation and Phonological Processing as Multiple Mediators. Behav. Brain Res. 2021, $396,112859$. [CrossRef]

101. Newbury, D.F.; Paracchini, S.; Scerri, T.S.; Winchester, L.; Addis, L.; Richardson, A.J.; Walter, J.; Stein, J.F.; Talcott, J.B.; Monaco, A.P. Investigation of Dyslexia and SLI Risk Variants in Reading- and Language-Impaired Subjects. Behav. Genet. 2010, 41, 90-104 [CrossRef] [PubMed]

102. Matsson, H.; Huss, M.; Persson, H.; Einarsdottir, E.; Tiraboschi, E.; Nopola-Hemmi, J.; Schumacher, J.; Neuhoff, N.; Warnke, A.; Lyytinen, H.; et al. Polymorphisms in DCDC2 and S100B associate with developmental dyslexia. J. Hum. Genet. 2015, 60, 399-401. [CrossRef] [PubMed]

103. Carrion-Castillo, A.; Van Bergen, E.; Vino, A.; Van Zuijen, T.; De Jong, P.F.; Francks, C.; Fisher, S.E. Evaluation of results from genome-wide studies of language and reading in a novel independent dataset. Genes Brain Behav. 2016, 15, 531-541. [CrossRef]

104. Luciano, M.; Gow, A.J.; Pattie, A.; Bates, T.C.; Deary, I.J. The Influence of Dyslexia Candidate Genes on Reading Skill in Old Age. Behav. Genet. 2018, 48, 351-360. [CrossRef]

105. Abbott, R.D.; Raskind, W.H.; Matsushita, M.; Price, N.D.; Richards, T.; Berninger, V.W. Patterns of biomarkers for three phenotype profiles of persisting specific learning disabilities during middle childhood and early adolescence: A preliminary study. Biomark. Genes 2017, 1, 103.

106. Meaburn, E.L.; Harlaar, N.; Craig, I.W.; Schalkwyk, L.C.; Plomin, R. Quantitative trait locus association scan of early reading disability and ability using pooled DNA and 100K SNP microarrays in a sample of 5760 children. Mol. Psychiatry 2007, 13, 729-740. [CrossRef] [PubMed]

107. Eicher, J.D.; Powers, N.R.; Miller, L.L.; Akshoomoff, N.; Amaral, D.G.; Bloss, C.S.; Libiger, O.; Schork, N.J.; Darst, B.F.; Casey, B.J.; et al. Genome-wide association study of shared components of reading disability and language impairment. Genes Brain Behav. 2013, 12, 792-801. [CrossRef] [PubMed]

108. Luciano, M.; Evans, D.M.; Hansell, N.K.; Medland, S.E.; Montgomery, G.W.; Martin, N.; Wright, M.J.; Bates, T.C. A genome-wide association study for reading and language abilities in two population cohorts. Genes Brain Behav. 2013, 12, 645-652. [CrossRef]

109. Gialluisi, A.; Newbury, D.F.; Wilcutt, E.G.; Olson, R.K.; DeFries, J.C.; Brandler, W.M.; Pennington, B.F.; Smith, S.D.; Scerri, T.S.; Simpson, N.H.; et al. Genome-wide screening for DNA variants associated with reading and language traits. Genes Brain Behav. 2014, 13, 686-701. [CrossRef] [PubMed]

110. Truong, D.T.; Adams, A.K.; Paniagua, S.; Frijters, J.C.; Boada, R.; Hill, D.E.; Lovett, M.W.; Mahone, E.M.; Willcutt, E.G.; Wolf, M.; et al. Multivariate genome-wide association study of rapid automatised naming and rapid alternating stimulus in Hispanic American and African-American youth. J. Med. Genet. 2019, 56, 557-566. [CrossRef]

111. Devanna, P.; Chen, X.S.; Ho, J.; Gajewski, D.; Smith, S.D.; Gialluisi, A.; Francks, C.; Fisher, S.E.; Newbury, D.F.; Vernes, S.C. Next-gen sequencing identifies non-coding variation disrupting miRNA-binding sites in neurological disorders. Mol. Psychiatry 2018, 23, 1375-1384. [CrossRef]

112. Müller, B.; Schaadt, G.; Boltze, J.; Emmrich, F.; Skeide, M.A.; Neef, N.E.; Kraft, I.; Brauer, J.; Friederici, A.D.; Kirsten, H.; et al. ATP2C2andDYX1C1 are putative modulators of dyslexia-related MMR. Brain Behav. 2017, 7, e00851. [CrossRef]

113. Czamara, D.; Bruder, J.; Becker, J.; Bartling, J.; Hoffmann, P.; Ludwig, K.U.; Müller-Myhsok, B.; Schulte-Körne, G. Association of a Rare Variant with Mismatch Negativity in a Region between KIAA0319 and DCDC2 in Dyslexia. Behav. Genet. 2010, 41, 110-119. [CrossRef]

114. Gialluisi, A.; Andlauer, T.F.M.; Mirza-Schreiber, N.; Moll, K.; Becker, J.; Hoffmann, P.; Ludwig, K.U.; Czamara, D.; Pourcain, B.S.; Brandler, W.; et al. Genome-wide association scan identifies new variants associated with a cognitive predictor of dyslexia. Transl. Psychiatry 2019, 9, 1-15. [CrossRef]

115. Selzam, S.; Dale, P.S.; Wagner, R.K.; DeFries, J.C.; Cederlöf, M.; O’Reilly, P.F.; Krapohl, E.; Plomin, R. Genome-Wide Polygenic Scores Predict Reading Performance throughout the School Years. Sci. Stud. Read. 2017, 21, 334-349. [CrossRef]

116. Harlaar, N.; Trzaskowski, M.; Dale, P.S.; Plomin, R. Word Reading Fluency: Role of Genome-Wide Single-Nucleotide Polymorphisms in Developmental Stability and Correlations with Print Exposure. Child. Dev. 2014, 85, 1190-1205. [CrossRef]

117. Docherty, S.J.; Kovas, Y.; Plomin, R. Gene-Environment Interaction in the Etiology of Mathematical Ability Using SNP Sets. Behav. Genet. 2011, 41, 141-154. [CrossRef] [PubMed]

118. Ludwig, K.U.; Sämann, P.; Alexander, M.; Becker, J.; Bruder, J.; Moll, K.; Spieler, D.; Czisch, M.; Warnke, A.; Docherty, S.J.; et al. A common variant in Myosin-18B contributes to mathematical abilities in children with dyslexia and intraparietal sulcus variability in adults. Transl. Psychiatry 2013, 3, e229. [CrossRef] [PubMed] 
119. Pettigrew, K.A.; Valles, S.F.F.; Moll, K.; Northstone, K.; Ring, S.; Pennell, C.; Wang, C.; Leavett, R.; Hayiou-Thomas, M.E.; Thompson, P.; et al. Lack of replication for the myosin-18B association with mathematical ability in independent cohorts. Genes Brain Behav. 2015, 14, 369-376. [CrossRef] [PubMed]

120. Baron-Cohen, S.; Murphy, L.; Chakrabarti, B.; Craig, I.; Mallya, U.; Lakatošová, S.; Rehnstrom, K.; Peltonen, L.; Wheelwright, S.; Allison, C.; et al. A Genome Wide Association Study of Mathematical Ability Reveals an Association at Chromosome 3q29, a Locus Associated with Autism and Learning Difficulties: A Preliminary Study. PLoS ONE 2014, 9, e96374. [CrossRef]

121. Chen, H.; Gu, X.-H.; Zhou, Y.; Ge, Z.; Wang, B.; Siok, W.T.; Wang, G.; Huen, M.; Jiang, Y.; Tan, L.-H.; et al. A Genome-Wide Association Study Identifies Genetic Variants Associated with Mathematics Ability. Sci. Rep. 2017, 7, srep40365. [CrossRef] [PubMed]

122. Girirajan, S.; Brkanac, Z.; Coe, B.P.; Baker, C.; Vives, L.; Vu, T.H.; Shafer, N.; Bernier, R.; Ferrero, G.B.; Silengo, M.; et al. Relative Burden of Large CNVs on a Range of Neurodevelopmental Phenotypes. PLoS Genet. 2011, 7, e1002334. [CrossRef]

123. Douard, E.; Zeribi, A.; Schramm, C.; Tamer, P.; Loum, M.A.; Nowak, S.; Saci, Z.; Lord, M.-P.; Rodríguez-Herreros, B.; Jean-Louis, M.; et al. Effect Sizes of Deletions and Duplications on Autism Risk across the Genome. Am. J. Psychiatry 2021, 178, 87-98. [CrossRef]

124. Yuan, H.; Shangguan, S.; Li, Z.; Luo, J.; Su, J.; Yao, R.; Zhang, S.; Liang, C.; Chen, Q.; Gao, Z.; et al. CNV profiles of Chinese pediatric patients with developmental disorders. Genet. Med. 2021, 1-10. [CrossRef]

125. Huang, A.Y.; Yu, D.; Davis, L.K.; Sul, J.H.; Tsetsos, F.; Ramensky, V.; Zelaya, I.; Ramos, E.M.; Osiecki, L.; Chen, J.A.; et al. Rare Copy Number Variants in NRXN1 and CNTN6 Increase Risk for Tourette Syndrome. Neuron 2017, 94, 1101-1111.e7. [CrossRef] [PubMed]

126. Wang, Y.; Xu, X.; Maglic, D.; Dill, M.T.; Mojumdar, K.; Ng, P.K.-S.; Jeong, K.J.; Tsang, Y.H.; Moreno, D.; Bhavana, V.H.; et al. Comprehensive Molecular Characterization of the Hippo Signaling Pathway in Cancer. Cell Rep. 2018, 25, 1304-1317.e5. [CrossRef] [PubMed]

127. Simpson, N.H.; The SLI Consortium; Ceroni, F.; Reader, R.H.; Covill, L.E.; Knight, J.C.; Hennessy, E.R.; Bolton, P.F.; ContiRamsden, G.; O'Hare, A.; et al. Genome-wide analysis identifies a role for common copy number variants in specific language impairment. Eur. J. Hum. Genet. 2015, 23, 1370-1377. [CrossRef] [PubMed]

128. Gialluisi, A.; Visconti, A.; Willcutt, E.G.; Smith, S.D.; Pennington, B.F.; Falchi, M.; DeFries, J.C.; Olson, R.K.; Francks, C.; Fisher, S.E. Investigating the effects of copy number variants on reading and language performance. J. Neurodev. Disord. 2016, 8, 17. [CrossRef] [PubMed]

129. Veerappa, A.M.; Saldanha, M.; Padakannaya, P.; Ramachandra, N.B. Genome-wide copy number scan identifies disruption of PCDH11X in developmental dyslexia. Am. J. Med. Genet. Part. B Neuropsychiatr. Genet. 2013, 162, 889-897. [CrossRef]

130. Veerappa, A.M.; Saldanha, M.; Padakannaya, P.; Ramachandra, N.B. Family based genome-wide copy number scan identifies complex rearrangements at 17q21.31 in dyslexics. Am. J. Med. Genet. Part. B Neuropsychiatr. Genet. 2014, 165, 572-580. [CrossRef]

131. De Smedt, B.; Swillen, A.; Verschaffel, L.; Ghesquière, P. Mathematical learning disabilities in children with 22q11.2 deletion syndrome: A review. Dev. Disabil. Res. Rev. 2009, 15, 4-10. [CrossRef]

132. Carvalho, M.R.S.; Vianna, G.; Oliveira, L.D.F.S.; Costa, A.J.; Pinheiro-Chagas, P.; Sturzenecker, R.; Zen, P.R.G.; Rosa, R.F.M.; De Aguiar, M.J.B.; Haase, V.G. Are 22q11.2 distal deletions associated with math difficulties? Am. J. Med. Genet. Part. A 2014, 164, 2256-2262. [CrossRef]

133. Mitrakos, A.; Sofokleous, C.; Papadimas, G.; Fryssira, H.; Kitsiou-Tzeli, S.; Tzetis, M.; Kosma, K. A Female Patient with Xq28 Microduplication Presenting with Myotubular Myopathy, Confirmed with a Custom-Designed X-array. Neuropediatrics 2018, 50, 061-063. [CrossRef]

134. Davis, J.M.; Searles, V.B.; Anderson, N.; Keeney, J.; Raznahan, A.; Horwood, L.J.; Fergusson, D.M.; Kennedy, M.A.; Giedd, J.; Sikela, J.M. DUF1220 copy number is linearly associated with increased cognitive function as measured by total IQ and mathematical aptitude scores. Qual. Life Res. 2014, 134, 67-75. [CrossRef]

135. Popesco, M.C.; MacLaren, E.J.; Hopkins, J.; Dumas, L.; Cox, M.; Meltesen, L.; McGavran, L.; Wyckoff, G.J.; Sikela, J.M. Human Lineage-Specific Amplification, Selection, and Neuronal Expression of DUF1220 Domains. Science 2006, 313, 1304-1307. [CrossRef]

136. Dehaene, S.; Piazza, M.; Pinel, P.; Cohen, L. Three Parietal Circuits for Number Processing. Cogn. Neuropsychol. 2003, 20, 487-506. [CrossRef] [PubMed]

137. Ischebeck, A.; Zamarian, L.; Schocke, M.; Delazer, M. Flexible transfer of knowledge in mental arithmetic-An fMRI study. NeuroImage 2009, 44, 1103-1112. [CrossRef]

138. Butterworth, B.; Varma, S.; Laurillard, D. Dyscalculia: From Brain to Education. Science 2011, 332, 1049-1053. [CrossRef] [PubMed]

139. Luo, R.; Sanders, S.J.; Tian, Y.; Voineagu, I.; Huang, N.; Chu, S.H.; Klei, L.; Cai, C.; Ou, J.; Lowe, J.K.; et al. Genome-wide Transcriptome Profiling Reveals the Functional Impact of Rare De Novo and Recurrent CNVs in Autism Spectrum Disorders. Am. J. Hum. Genet. 2012, 91, 38-55. [CrossRef]

140. Huguet, G.; Schramm, C.; Douard, E.; Tamer, P.; Main, A.; Monin, P.; England, J.; Jizi, K.; Renne, T.; Poirier, M.; et al. Genome-wide analysis of gene dosage in 24,092 individuals estimates that 10,000 genes modulate cognitive ability. Mol. Psychiatry 2021, 1-14. [CrossRef]

141. Yoon, K.-J.; Nguyen, H.N.; Ursini, G.; Zhang, F.; Kim, N.-S.; Wen, Z.; Makri, G.; Nauen, D.; Shin, J.H.; Park, Y.; et al. Modeling a Genetic Risk for Schizophrenia in iPSCs and Mice Reveals Neural Stem Cell Deficits Associated with Adherens Junctions and Polarity. Cell Stem Cell 2014, 15, 79-91. [CrossRef] [PubMed] 
142. De Ligt, J.; Willemsen, M.H.; Van Bon, B.W.; Kleefstra, T.; Yntema, H.G.; Kroes, T.; Silfhout, A.T.V.-V.; Koolen, D.A.; De Vries, P.; Gilissen, C.; et al. Diagnostic Exome Sequencing in Persons with Severe Intellectual Disability. N. Engl. J. Med. 2012, 367, 1921-1929. [CrossRef]

143. Iossifov, I.; O’Roak, B.J.; Sanders, S.J.; Ronemus, M.; Krumm, N.; Levy, D.; Stessman, H.A.; Witherspoon, K.T.; Vives, L.; Patterson, K.E.; et al. The contribution of de novo coding mutations to autism spectrum disorder. Nature 2014, 515, 216-221. [CrossRef]

144. Hiraide, T.; Yamoto, K.; Masunaga, Y.; Asahina, M.; Endoh, Y.; Ohkubo, Y.; Matsubayashi, T.; Tsurui, S.; Yamada, H.; Yanagi, K.; et al. Genetic and phenotypic analysis of 101 patients with developmental delay or intellectual disability using whole-exome sequencing. Clin. Genet. 2021. [CrossRef]

145. Adams, A.K.; Smith, S.D.; Truong, D.T.; Willcutt, E.G.; Olson, R.K.; DeFries, J.C.; Pennington, B.F.; Gruen, J.R. Enrichment of putatively damaging rare variants in the DYX2 locus and the reading-related genes CCDC136 and FLNC. Qual. Life Res. 2017, 136, 1395-1405. [CrossRef]

146. Einarsdottir, E.; Svensson, I.; Darki, F.; Peyrard-Janvid, M.; Lindvall, J.M.; Ameur, A.; Jacobsson, C.; Klingberg, T.; Kere, J.; Matsson, H. Mutation in CEP63 co-segregating with developmental dyslexia in a Swedish family. Qual. Life Res. 2015, 134, 1239-1248. [CrossRef] [PubMed]

147. Massinen, S.; Hokkanen, M.-E.; Matsson, H.; Tammimies, K.; Tapia-Páez, I.; Dahlström-Heuser, V.; Kuja-Panula, J.; Burghoorn, J.; Jeppsson, K.E.; Swoboda, P.; et al. Increased Expression of the Dyslexia Candidate Gene DCDC2 Affects Length and Signaling of Primary Cilia in Neurons. PLoS ONE 2011, 6, e20580. [CrossRef]

148. Tarkar, A.; Loges, N.T.; Slagle, C.E.; Francis, R.; Dougherty, G.W.; Tamayo, J.V.; Shook, B.; Cantino, M.; Schwartz, D.; Jahnke, C.; et al. DYX1C1 is required for axonemal dynein assembly and ciliary motility. Nat. Genet. 2013, 45, 995-1003. [CrossRef]

149. Chandrasekar, G.; Vesterlund, L.; Hultenby, K.; Tapia-Páez, I.; Kere, J. The Zebrafish Orthologue of the Dyslexia Candidate Gene DYX1C1 Is Essential for Cilia Growth and Function. PLoS ONE 2013, 8, e63123. [CrossRef] [PubMed]

150. Schueler, M.; Braun, D.A.; Chandrasekar, G.; Gee, H.Y.; Klasson, T.D.; Halbritter, J.; Bieder, A.; Porath, J.D.; Airik, R.; Zhou, W.; et al. DCDC2 Mutations Cause a Renal-Hepatic Ciliopathy by Disrupting Wnt Signaling. Am. J. Hum. Genet. 2015, 96, 81-92. [CrossRef] [PubMed]

151. Grati, M.; Chakchouk, I.; Ma, Q.; Bensaid, M.; DeSmidt, A.; Turki, N.; Yan, D.; Baanannou, A.; Mittal, R.; Driss, N.; et al. A missense mutation in DCDC2 causes human recessive deafness DFNB66, likely by interfering with sensory hair cell and supporting cell cilia length regulation. Hum. Mol. Genet. 2015, 24, 2482-2491. [CrossRef]

152. Girard, M.; Bizet, A.A.; Lachaux, A.; Gonzales, E.; Filhol, E.; Collardeau-Frachon, S.; Jeanpierre, C.; Henry, C.; Fabre, M.; Viremouneix, L.; et al. DCDC2Mutations Cause Neonatal Sclerosing Cholangitis. Hum. Mutat. 2016, 37, 1025-1029. [CrossRef] [PubMed]

153. Grammatikopoulos, T.; Sambrotta, M.; Strautnieks, S.; Foskett, P.; Knisely, A.; Wagner, B.; Deheragoda, M.; Starling, C.; MieliVergani, G.; Smith, J.; et al. Mutations in DCDC2 (doublecortin domain containing protein 2) in neonatal sclerosing cholangitis. J. Hepatol. 2016, 65, 1179-1187. [CrossRef] [PubMed]

154. Bieder, A.; Einarsdottir, E.; Matsson, H.; Nilsson, H.E.; Eisfeldt, J.; Dragomir, A.; Paucar, M.; Granberg, T.; Li, T.-Q.; Lindstrand, A.; et al. Rare variants in dynein heavy chain genes in two individuals with situs inversus and developmental dyslexia: A case report. BMC Med. Genet. 2020, 21, 1-9. [CrossRef] [PubMed]

155. Trulioff, A.; Ermakov, A.; Malashichev, Y. Primary Cilia as a Possible Link between Left-Right Asymmetry and Neurodevelopmental Diseases. Genes 2017, 8, 48. [CrossRef]

156. Mascheretti, S.; Bureau, A.; Battaglia, M.; Simone, D.; Quadrelli, E.; Croteau, J.; Cellino, M.R.; Giorda, R.; Beri, S.; Maziade, M.; et al. An assessment of gene-by-environment interactions in developmental dyslexia-related phenotypes. Genes Brain Behav. 2012, 12, 47-55. [CrossRef] [PubMed]

157. Price, K.M.; Wigg, K.G.; Feng, Y.; Blokland, K.; Wilkinson, M.; He, G.; Kerr, E.N.; Carter, T.-C.; Guger, S.L.; Lovett, M.W.; et al. Genome-wide association study of word reading: Overlap with risk genes for neurodevelopmental disorders. Genes Brain Behav. 2020, 19, e12648. [CrossRef]

158. The Brainstorm Consortium; Anttila, V.; Bulik-Sullivan, B.; Finucane, H.K.; Walters, R.K.; Bras, J.; Duncan, L.; Escott-Price, V.; Falcone, G.J.; Gormley, P.; et al. Analysis of shared heritability in common disorders of the brain. Science 2018, 360, eaap8757. [CrossRef]

159. Lee, P.H.; Anttila, V.; Won, H.; Feng, Y.-C.A.; Rosenthal, J.; Zhu, Z.; Tucker-Drob, E.M.; Nivard, M.G.; Grotzinger, A.D.; Posthuma, D.; et al. Genomic Relationships, Novel Loci, and Pleiotropic Mechanisms across Eight Psychiatric Disorders. Cell 2019, 179, 1469-1482.e11. [CrossRef]

160. Grotzinger, A.D. Shared genetic architecture across psychiatric disorders. Psychol. Med. 2021, 1-7. [CrossRef]

161. Cross-Disorder Group of the Psychiatric Genomics Consortium. Genetic relationship between five psychiatric disorders estimated from genome-wide SNPs. Nat. Genet. 2013, 45, 984-994. [CrossRef]

162. Rommelse, N.N.J.; Franke, B.; Geurts, H.M.; Hartman, C.A.; Buitelaar, J.K. Shared heritability of attention-deficit/hyperactivity disorder and autism spectrum disorder. Eur. Child. Adolesc. Psychiatry 2010, 19, 281-295. [CrossRef]

163. Lionel, A.C.; Crosbie, J.; Barbosa, N.; Goodale, T.; Thiruvahindrapuram, B.; Rickaby, J.; Gazzellone, M.; Carson, A.R.; Howe, J.L.; Wang, Z.; et al. Rare Copy Number Variation Discovery and Cross-Disorder Comparisons Identify Risk Genes for ADHD. Sci. Transl. Med. 2011, 3, 95ra75. [CrossRef] [PubMed] 
164. McGrath, L.M.; Yu, D.; Marshall, C.; Davis, L.K.; Thiruvahindrapuram, B.; Li, B.; Cappi, C.; Gerber, G.; Wolf, A.; Schroeder, F.A.; et al. Copy Number Variation in Obsessive-Compulsive Disorder and Tourette Syndrome: A Cross-Disorder Study. J. Am. Acad. Child. Adolesc. Psychiatry 2014, 53, 910-919. [CrossRef] [PubMed]

165. Yu, D.; Mathews, C.A.; Scharf, J.M.; Neale, B.M.; Davis, L.K.; Gamazon, E.R.; Derks, E.M.; Evans, P.; Edlund, C.K.; Crane, J.; et al. Cross-Disorder Genome-Wide Analyses Suggest a Complex Genetic Relationship between Tourette's Syndrome and OCD. Am. J. Psychiatry 2015, 172, 82-93. [CrossRef] [PubMed]

166. Yilmaz, Z.; Halvorsen, M.; Bryois, J.; Yu, D.; Thornton, L.M.; Zerwas, S.; Micali, N.; Moessner, R.; Burton, C.L.; Zai, G.; et al. Examination of the shared genetic basis of anorexia nervosa and obsessive-compulsive disorder. Mol. Psychiatry 2020, 25, 2036-2046. [CrossRef] [PubMed]

167. Yang, Z.; Wu, H.; Lee, P.H.; Tsetsos, F.; Davis, L.K.; Yu, D.; Lee, S.H.; Dalsgaard, S.; Haavik, J.; Barta, C.; et al. Investigating Shared Genetic Basis across Tourette Syndrome and Comorbid Neurodevelopmental Disorders along the Impulsivity-Compulsivity Spectrum. Biol. Psychiatry 2021. [CrossRef]

168. McArthur, G.; Hogben, J.H.; Edwards, V.T.; Heath, S.M.; Mengler, E.D. On the "Specifics" of Specific Reading Disability and Specific Language Impairment. J. Child. Psychol. Psychiatry 2000, 41, 869-874. [CrossRef]

169. Wadsworth, S.J.; DeFries, J.C.; Willcutt, E.G.; Pennington, B.F.; Olson, R.K. The Colorado Longitudinal Twin Study of Reading Difficulties and ADHD: Etiologies of Comorbidity and Stability. Twin Res. Hum. Genet. 2015, 18, 755-761. [CrossRef] [PubMed]

170. Willcutt, E.G.; Pennington, B.F.; DeFries, J.C. Twin Study of the Etiology of Comorbidity between Reading Disability and Attention-Deficit/Hyperactivity Disorder. Am. J. Med. Genet. 2000, 96, 293-301. [CrossRef]

171. Willcutt, E.G.; Pennington, B.F.; Olson, R.K.; DeFries, J.C. Understanding comorbidity: A twin study of reading disability and attention-deficit/hyperactivity disorder. Am. J. Med. Genet. Part. B Neuropsychiatr. Genet. 2007, 144B, 709-714. [CrossRef]

172. Mascheretti, S.; Trezzi, V.; Giorda, R.; Boivin, M.; Plourde, V.; Vitaro, F.; Brendgen, M.; Dionne, G.; Marino, C. Complex effects of dyslexia risk factors account for ADHD traits: Evidence from two independent samples. J. Child. Psychol. Psychiatry 2016, 58, 75-82. [CrossRef] [PubMed]

173. Verhoef, E.; iPSYCH-Broad-PGC ADHD Consortium; Demontis, D.; Burgess, S.; Shapland, C.Y.; Dale, P.S.; Okbay, A.; Neale, B.M.; Faraone, S.V.; Stergiakouli, E.; et al. Disentangling polygenic associations between attention-deficit/hyperactivity disorder, educational attainment, literacy and language. Transl. Psychiatry 2019, 9, 35. [CrossRef] [PubMed]

174. Hendren, R.L.; Haft, S.L.; Black, J.M.; White, N.C.; Hoeft, F. Recognizing Psychiatric Comorbidity With Reading Disorders. Front. Psychiatry 2018, 9, 101. [CrossRef]

175. McGrath, L.M.; Stoodley, C.J. Are there shared neural correlates between dyslexia and ADHD? A meta-analysis of voxel-based morphometry studies. J. Neurodev. Disord. 2019, 11, 1-20. [CrossRef]

176. Langer, N.; Benjamin, C.; Becker, B.L.C.; Gaab, N. Comorbidity of reading disabilities and ADHD: Structural and functional brain characteristics. Hum. Brain Mapp. 2019, 40, 2677-2698. [CrossRef] [PubMed]

177. SFARI Gene-Welcome. Available online: https://gene.sfari.org/ (accessed on 2 April 2021).

178. Norton, E.S.; Beach, S.D.; DE Gabrieli, J. Neurobiology of dyslexia. Curr. Opin. Neurobiol. 2015, 30, 73-78. [CrossRef]

179. Langer, N.; Peysakhovich, B.; Zuk, J.; Drottar, M.; Sliva, D.D.; Smith, S.; Becker, B.L.C.; Grant, P.E.; Gaab, N. White Matter Alterations in Infants at Risk for Developmental Dyslexia. Cereb. Cortex 2015, 27, 1027-1036. [CrossRef]

180. Wang, X.; Guo, X.; Chen, L.; Liu, Y.; Goldberg, M.E.; Xu, H. Auditory to Visual Cross-Modal Adaptation for Emotion: Psychophysical and Neural Correlates. Cereb. Cortex 2016, 27, 1337-1346. [CrossRef] [PubMed]

181. Grasby, K.L.; Jahanshad, N.; Painter, J.N.; Colodro-Conde, L.; Bralten, J.; Hibar, D.P.; Lind, P.A.; Pizzagalli, F.; Ching, C.R.K.; McMahon, M.A.B.; et al. The genetic architecture of the human cerebral cortex. Science 2020, 367, eaay6690. [CrossRef] [PubMed]

182. Darki, F.; Peyrard-Janvid, M.; Matsson, H.; Kere, J.; Klingberg, T. Three Dyslexia Susceptibility Genes, DYX1C1, DCDC2, and KIAA0319, Affect Temporo-Parietal White Matter Structure. Biol. Psychiatry 2012, 72, 671-676. [CrossRef]

183. Scerri, T.S.; Darki, F.; Newbury, D.F.; Whitehouse, A.J.O.; Peyrard-Janvid, M.; Matsson, H.; Ang, Q.W.; Pennell, C.E.; Ring, S.; Stein, J.; et al. The Dyslexia Candidate Locus on 2p12 Is Associated with General Cognitive Ability and White Matter Structure. PLoS ONE 2012, 7, e50321. [CrossRef] [PubMed]

184. Pinel, P.; Dehaene, S. Genetic and environmental contributions to brain activation during calculation. NeuroImage 2013, 81, 306-316. [CrossRef] [PubMed]

185. Rotzer, S.; Kucian, K.; Martin, E.; von Aster, M.; Klaver, P.; Loenneker, T. Optimized voxel-based morphometry in children with developmental dyscalculia. NeuroImage 2008, 39, 417-422. [CrossRef] [PubMed]

186. Rotzer, S.; Loenneker, T.; Kucian, K.; Martin, E.; Klaver, P.; von Aster, M. Dysfunctional neural network of spatial working memory contributes to developmental dyscalculia. Neuropsychol. 2009, 47, 2859-2865. [CrossRef]

187. Peters, L.; Bulthé, J.; Daniels, N.; De Beeck, H.O.; De Smedt, B. Dyscalculia and dyslexia: Different behavioral, yet similar brain activity profiles during arithmetic. NeuroImage Clin. 2018, 18, 663-674. [CrossRef] [PubMed]

188. Bulthé, J.; Prinsen, J.; Vanderauwera, J.; Duyck, S.; Daniels, N.; Gillebert, C.R.; Mantini, D.; De Beeck, H.P.O.; De Smedt, B. Multi-method brain imaging reveals impaired representations of number as well as altered connectivity in adults with dyscalculia. NeuroImage 2019, 190, 289-302. [CrossRef] [PubMed]

189. Li, M.; The GRaD Study Consortium; Malins, J.G.; DeMille, M.M.C.; Lovett, M.W.; Truong, N.T.; Epstein, K.; Lacadie, C.; Mehta, C.; Bosson-Heenan, J.; et al. A molecular-genetic and imaging-genetic approach to specific comprehension difficulties in children. NPJ Sci. Learn. 2018, 3, 20. [CrossRef] 
190. Centanni, T.; Pantazis, D.; Truong, D.; Gruen, J.; Gabrieli, J.; Hogan, T. Increased variability of stimulus-driven cortical responses is associated with genetic variability in children with and without dyslexia. Dev. Cogn. Neurosci. 2018, 34, 7-17. [CrossRef] [PubMed]

191. Skeide, M.A.; Wehrmann, K.; Emami, Z.; Kirsten, H.; Hartmann, A.M.; Rujescu, D.; LEGASCREEN Consortium. Neurobiological origins of individual differences in mathematical ability. PLoS Biol. 2020, 18, e3000871. [CrossRef] [PubMed]

192. Skeide, M.A.; Kraft, I.; Müller, B.; Schaadt, G.; Neef, N.E.; Brauer, J.; Wilcke, A.; Kirsten, H.; Boltze, J.; Friederici, A.D. NRSN1associated grey matter volume of the visual word form area reveals dyslexia before school. Brain 2016, 139, $2792-2803$. [CrossRef]

193. Guttorm, T.K.; Tolvanen, A.; Lyytinen, H. Event-related potentials in newborns with and without familial risk for dyslexia: Principal component analysis reveals differences between the groups. J. Neural Transm. 2003, 110, 1059-1074. [CrossRef]

194. Ozernov-Palchik, O.; Gaab, N. Tackling the 'dyslexia paradox': Reading brain and behavior for early markers of developmental dyslexia. Wiley Interdiscip. Rev. Cogn. Sci. 2016, 7, 156-176. [CrossRef]

195. Gabel, L.A.; Gibson, C.J.; Gruen, J.R.; LoTurco, J.J. Progress towards a cellular neurobiology of reading disability. Neurobiol. Dis. 2010, 38, 173-180. [CrossRef]

196. Guidi, L.G.; Velayos-Baeza, A.; Martinez-Garay, I.; Monaco, A.P.; Paracchini, S.; Bishop, D.V.M.; Molnár, Z. The neuronal migration hypothesis of dyslexia: A critical evaluation 30 years on. Eur. J. Neurosci. 2018, 48, 3212-3233. [CrossRef]

197. Tammimies, K.; Bieder, A.; Lauter, G.; Sugiaman-Trapman, D.; Torchet, R.; Hokkanen, M.; Burghoorn, J.; Castren, E.; Kere, J.; Tapia-Páez, I.; et al. Ciliary dyslexia candidate genes DYX1C1 and DCDC2 are regulated by Regulatory Factor X (RFX) transcription factors through X-box promoter motifs. FASEB J. 2016, 30, 3578-3587. [CrossRef] [PubMed]

198. Murphy, S.M.; Preble, A.M.; Patel, U.K.; O’Connell, K.L.; Dias, D.P.; Moritz, M.; Agard, D.; Stults, J.T.; Stearns, T. GCP5 and GCP6: Two New Members of the Human $\gamma$-Tubulin Complex. Mol. Biol. Cell 2001, 12, 3340-3352. [CrossRef] [PubMed]

199. Rauch, A.; Thiel, C.T.; Schindler, D.; Wick, U.; Crow, Y.J.; Ekici, A.B.; Van Essen, A.J.; Goecke, T.O.; Al-Gazali, L.; Chrzanowska, K.H.; et al. Mutations in the Pericentrin (PCNT) Gene Cause Primordial Dwarfism. Science 2008, 319, 816-819. [CrossRef] [PubMed]

200. Sir, J.-H.; Barr, A.R.; Nicholas, A.K.; Carvalho, O.P.; Khurshid, M.; Sossick, A.; Reichelt, S.; D’Santos, C.; Woods, C.G.; Gergely, F. A primary microcephaly protein complex forms a ring around parental centrioles. Nat. Genet. 2011, 43, 1147-1153. [CrossRef] [PubMed]

201. Marjanović, M.; Sánchez-Huertas, C.; Terré, B.; Gómez, R.; Scheel, J.F.; Pacheco, S.; Knobel, P.A.; Martínez-Marchal, A.; Aivio, S.; Palenzuela, L.; et al. CEP63 deficiency promotes p53-dependent microcephaly and reveals a role for the centrosome in meiotic recombination. Nat. Commun. 2015, 6, 7676. [CrossRef]

202. Bieder, A.; Yoshihara, M.; Katayama, S.; Krjutškov, K.; Falk, A.; Kere, J.; Tapia-Páez, I. Dyslexia Candidate Gene and Ciliary Gene Expression Dynamics during Human Neuronal Differentiation. Mol. Neurobiol. 2020, 57, 2944-2958. [CrossRef]

203. Paracchini, S.; Diaz, R.; Stein, J. Advances in Dyslexia Genetics—New Insights into the Role of Brain Asymmetries. Advances in Genetics 2016, 96, 53-97. [CrossRef]

204. GTEx Portal. Available online: https://gtexportal.org/home/ (accessed on 2 April 2021).

205. Yoshimoto, R.; Okawa, K.; Yoshida, M.; Ohno, M.; Kataoka, N. Identification of a novel component C2ORF3 in the lariat-intron complex: Lack of C2ORF3 interferes with pre-mRNA splicing via intron turnover pathway. Genes Cells 2014, 19, 78-87. [CrossRef]

206. Kidd, T.; Brose, K.; Mitchell, K.J.; Fetter, R.D.; Tessier-Lavigne, M.; Goodman, C.S.; Tear, G. Roundabout Controls Axon Crossing of the CNS Midline and Defines a Novel Subfamily of Evolutionarily Conserved Guidance Receptors. Cell 1998, 92, 205-215. [CrossRef]

207. Faedo, A.; Borello, U.; Rubenstein, J.L.R. Repression of Fgf Signaling by Sprouty1-2 Regulates Cortical Patterning in Two Distinct Regions and Times. J. Neurosci. 2010, 30, 4015-4023. [CrossRef]

208. Kim, H.J.; Bar-Sagi, D. Modulation of signalling by Sprouty: A developing story. Nat. Rev. Mol. Cell Biol. 2004, 5, 441-450. [CrossRef] [PubMed]

209. McGrath, J.; Somlo, S.; Makova, S.; Tian, X.; Brueckner, M. Two Populations of Node Monocilia Initiate Left-Right Asymmetry in the Mouse. Cell 2003, 114, 61-73. [CrossRef]

210. Che, A.; Truong, N.T.; Fitch, R.H.; LoTurco, J.J. Mutation of the Dyslexia-Associated GeneDcdc2Enhances Glutamatergic Synaptic Transmission between Layer 4 Neurons in Mouse Neocortex. Cereb. Cortex 2016, 26, 3705-3718. [CrossRef] [PubMed]

211. Paracchini, S.; Thomas, A.; Castro, S.; Lai, C.; Paramasivam, M.; Wang, Y.; Keating, B.J.; Taylor, J.M.; Hacking, D.F.; Scerri, T.; et al. The chromosome 6p22 haplotype associated with dyslexia reduces the expression of KIAA0319, a novel gene involved in neuronal migration. Hum. Mol. Genet. 2006, 15, 1659-1666. [CrossRef] [PubMed]

212. Peschansky, V.J.; Burbridge, T.J.; Volz, A.J.; Fiondella, C.; Wissner-Gross, Z.; Galaburda, A.M.; Turco, J.J.L.; Rosen, G.D. The Effect of Variation in Expression of the Candidate Dyslexia Susceptibility Gene Homolog Kiaa0319 on Neuronal Migration and Dendritic Morphology in the Rat. Cereb. Cortex 2009, 20, 884-897. [CrossRef]

213. Franquinho, F.; Nogueira-Rodrigues, J.; Duarte, J.M.; Esteves, S.S.; Carter-Su, C.; Monaco, A.P.; Molnár, Z.; Velayos-Baeza, A.; Brites, P.; Sousa, M.M. The Dyslexia-susceptibility Protein KIAA0319 Inhibits Axon Growth through Smad2 Signaling. Cereb. Cortex 2017, 27, 1732-1747. [CrossRef] 
214. Poliak, S.; Gollan, L.; Martinez, R.; Custer, A.; Einheber, S.; Salzer, J.L.; Trimmer, J.S.; Shrager, P.; Peles, E. Caspr2, a New Member of the Neurexin Superfamily, Is Localized at the Juxtaparanodes of Myelinated Axons and Associates with K+Channels. Neuron 1999, 24, 1037-1047. [CrossRef]

215. Saint-Martin, M.; Joubert, B.; Pellier-Monnin, V.; Pascual, O.; Noraz, N.; Honnorat, J. Contactin-associated protein-like 2, a protein of the neurexin family involved in several human diseases. Eur. J. Neurosci. 2018, 48, 1906-1923. [CrossRef]

216. Bozdagi, O.; Sakurai, T.; Dorr, N.; Pilorge, M.; Takahashi, N.; Buxbaum, J.D. Haploinsufficiency of Cyfip1 Produces Fragile X-Like Phenotypes in Mice. PLoS ONE 2012, 7, e42422. [CrossRef]

217. Pathania, M.; Davenport, E.C.; Muir, J.; Sheehan, D.F.; López-Doménech, G.; Kittler, J.T. The autism and schizophrenia associated gene CYFIP1 is critical for the maintenance of dendritic complexity and the stabilization of mature spines. Transl. Psychiatry 2014, 4, e374. [CrossRef]

218. Wang, Y.; Paramasivam, M.; Thomas, A.; Bai, J.; Kaminen-Ahola, N.; Kere, J.; Voskuil, J.; Rosen, G.; Galaburda, A.; LoTurco, J. DYX1C1 functions in neuronal migration in developing neocortex. Neuroscience 2006, 143, 515-522. [CrossRef]

219. Massinen, S.; Tammimies, K.; Tapia-Páez, I.; Matsson, H.; Hokkanen, M.-E.; Söderberg, O.; Landegren, U.; Castrén, E.; Gustafsson, J.-Å.; Treuter, E.; et al. Functional interaction of DYX1C1 with estrogen receptors suggests involvement of hormonal pathways in dyslexia. Hum. Mol. Genet. 2009, 18, 2802-2812. [CrossRef]

220. Grumet, M.; Flaccus, A.; Margolis, R.U. Functional characterization of chondroitin sulfate proteoglycans of brain: Interactions with neurons and neural cell adhesion molecules. J. Cell Biol. 1993, 120, 815-824. [CrossRef] [PubMed]

221. Friedlander, D.R.; Milev, P.; Karthikeyan, L.; Margolis, R.K.; Grumet, M. The neuronal chondroitin sulfate proteoglycan neurocan binds to the neural cell adhesion molecules Ng-CAM/L1/NILE and N-CAM, and inhibits neuronal adhesion and neurite outgrowth. J. Cell Biol. 1994, 125, 669-680. [CrossRef] [PubMed]

222. Doxsey, S.J.; Stein, P.; Evans, L.; Calarco, P.D.; Kirschner, M. Pericentrin, a highly conserved centrosome protein involved in microtubule organization. Cell 1994, 76, 639-650. [CrossRef]

223. Takahashi, M.; Yamagiwa, A.; Nishimura, T.; Mukai, H.; Ono, Y. Centrosomal Proteins CG-NAP and Kendrin Provide Microtubule Nucleation Sites by Anchoring $\gamma$-Tubulin Ring Complex. Mol. Biol. Cell 2002, 13, 3235-3245. [CrossRef] [PubMed]

224. Reeves, R.H.; Yao, J.; Crowley, M.R.; Buck, S.; Zhang, X.; Yarowsky, P.; Gearhart, J.D.; Hilt, D.C. Astrocytosis and axonal proliferation in the hippocampus of S100b transgenic mice. Proc. Natl. Acad. Sci. USA 1994, 91, 5359-5363. [CrossRef]

225. Yamaguchi, F.; Umeda, Y.; Shimamoto, S.; Tsuchiya, M.; Tokumitsu, H.; Tokuda, M.; Kobayashi, R. S100 Proteins Modulate Protein Phosphatase 5 Function. J. Biol. Chem. 2012, 287, 13787-13798. [CrossRef]

226. Gehman, L.T.; Meera, P.; Stoilov, P.; Shiue, L.; O’Brien, J.E.; Meisler, M.H.; Ares, M.; Otis, T.S.; Black, D.L. The splicing regulator Rbfox 2 is required for both cerebellar development and mature motor function. Genes Dev. 2012, 26, 445-460. [CrossRef]

227. ADHDgene Database. Available online: http://adhd.psych.ac.cn/index.do (accessed on 2 April 2021).

228. Proteinatlas The Human Protein Atlas. Available online: https://www.proteinatlas.org (accessed on 19 December 2019).

229. Uniprot Data Base. Available online: http:/ / www.uniprot.org/ (accessed on 10 October 2012).

230. Simpson, N.H.; Addis, L.; Brandler, W.M.; Slonims, V.; Clark, A.; Watson, J.; Scerri, T.S.; Hennessy, E.R.; Bolton, P.F.; ContiRamsden, G.; et al. Increased prevalence of sex chromosome aneuploidies in specific language impairment and dyslexia. Dev. Med. Child. Neurol. 2013, 56, 346-353. [CrossRef]

231. Leggett, V.; Jacobs, P.; Nation, K.; Scerif, G.; Bishop, D.V.M. Neurocognitive outcomes of individuals with a sex chromosome trisomy: XXX, XYY, or XXY: A systematic review. Dev. Med. Child. Neurol. 2010, 52, 119-129. [CrossRef]

232. Baker, J.M.; Reiss, A.L. A meta-analysis of math performance in Turner syndrome. Dev. Med. Child. Neurol. 2015, 58, 123-130. [CrossRef] [PubMed]

233. Le Gall, J.; Nizon, M.; Pichon, O.; Andrieux, J.; Audebert-Bellanger, S.; Baron, S.; Beneteau, C.; Bilan, F.; Boute, O.; Busa, T.; et al. Sex chromosome aneuploidies and copy-number variants: A further explanation for neurodevelopmental prognosis variability? Eur. J. Hum. Genet. 2017, 25, 930-934. [CrossRef] [PubMed]

234. Warling, A.; Liu, S.; Wilson, K.; Whitman, E.; LaLonde, F.M.; Clasen, L.S.; Blumenthal, J.D.; Raznahan, A. Sex chromosome aneuploidy alters the relationship between neuroanatomy and cognition. Am. J. Med. Genet. Part. C Semin. Med. Genet. 2020, 184, 493-505. [CrossRef] [PubMed]

235. Hong, D.S.; Reiss, A.L. Cognitive and neurological aspects of sex chromosome aneuploidies. Lancet Neurol. 2014, 13, 306-318. [CrossRef]

236. Rutter, M.; Caspi, A.; Fergusson, D.; Horwood, L.J.; Goodman, R.; Maughan, B.; Moffitt, T.E.; Meltzer, H.; Carroll, J. Sex Differences in Developmental Reading Disability. JAMA 2004, 291, 2007-2012. [CrossRef] [PubMed]

237. Quinn, J.M.; Wagner, R.K. Gender Differences in Reading Impairment and in the Identification of Impaired Readers. J. Learn. Disabil. 2015, 48, 433-445. [CrossRef] [PubMed]

238. Liu, L.; Wang, J.; Shao, S.; Luo, X.; Kong, R.; Zhang, X.; Song, R. Descriptive epidemiology of prenatal and perinatal risk factors in a Chinese population with reading disorder. Sci. Rep. 2016, 6, 36697. [CrossRef]

239. Arnett, A.B.; Pennington, B.F.; Peterson, R.L.; Willcutt, E.G.; DeFries, J.C.; Olson, R.K. Explaining the sex difference in dyslexia. J. Child. Psychol. Psychiatry 2017, 58, 719-727. [CrossRef]

240. Bonti, E.; School of Medicine, Aristotle University of Thessaloniki, Thessaloniki, Greece. Personal communication, 2021.

241. Robinson, E.B.; Lichtenstein, P.; Anckarsäter, H.; Happé, F.; Ronald, A. Examining and interpreting the female protective effect against autistic behavior. Proc. Natl. Acad. Sci. USA 2013, 110, 5258-5262. [CrossRef] 
242. Werling, D.M. The role of sex-differential biology in risk for autism spectrum disorder. Biol. Sex. Differ. 2016, 7, 1-18. [CrossRef] [PubMed]

243. Ferri, S.L.; Abel, T.; Brodkin, E.S. Sex Differences in Autism Spectrum Disorder: A Review. Curr. Psychiatry Rep. $2018,20,1-17$. [CrossRef] [PubMed]

244. Flannery, K.A.; Liederman, J.; Daly, L.; Schultz, J. Male prevalence for reading disability is found in a large sample of Black and White children free from ascertainment bias. J. Int. Neuropsychol. Soc. 2000, 6, 433-442. [CrossRef] [PubMed]

245. Harlaar, N.; Spinath, F.M.; Dale, P.S.; Plomin, R. Genetic influences on early word recognition abilities and disabilities: A study of 7-year-old twins. J. Child. Psychol. Psychiatry 2005, 46, 373-384. [CrossRef]

246. Hawke, J.L.; Wadsworth, S.J.; DeFries, J.C. Genetic influences on reading difficulties in boys and girls: The Colorado twin study. Dyslexia 2006, 12, 21-29. [CrossRef] [PubMed]

247. Gu, H.; Hou, F.; Liu, L.; Luo, X.; Nkomola, P.D.; Xie, X.; Li, X.; Song, R. Genetic variants in the CNTNAP2 gene are associated with gender differences among dyslexic children in China. EBioMedicine 2018, 34, 165-170. [CrossRef] [PubMed]

248. Carter, C.O.; Evans, K.A. Inheritance of congenital pyloric stenosis. J. Med. Genet. 1969, 6, 233-254. [CrossRef] [PubMed]

249. Taylor, M.J.; Lichtenstein, P.; Larsson, H.; Anckarsäter, H.; Greven, C.U.; Ronald, A. Is There a Female Protective Effect Against Attention-Deficit/Hyperactivity Disorder? Evidence From Two Representative Twin Samples. J. Am. Acad. Child. Adolesc. Psychiatry 2016, 55, 504-512.e2. [CrossRef]

250. Mitra, I.; Tsang, K.; Ladd-Acosta, C.; Croen, L.A.; Aldinger, K.A.; Hendren, R.L.; Traglia, M.; Lavillaureix, A.; Zaitlen, N.; Oldham, M.C.; et al. Pleiotropic Mechanisms Indicated for Sex Differences in Autism. PLoS Genet. 2016, 12, e1006425. [CrossRef] 